Portland State University

PDXScholar

6-11-1976

\title{
Contributions to Tualatin Ethnography: Subsistence and Ethnobiology
}

Henry B. Zenk

Portland State University

Follow this and additional works at: https://pdxscholar.library.pdx.edu/open_access_etds

Part of the Archaeological Anthropology Commons, and the Social and Cultural Anthropology Commons

Let us know how access to this document benefits you.

\section{Recommended Citation}

Zenk, Henry B., "Contributions to Tualatin Ethnography: Subsistence and Ethnobiology" (1976).

Dissertations and Theses. Paper 2279.

https://doi.org/10.15760/etd.2276

This Thesis is brought to you for free and open access. It has been accepted for inclusion in Dissertations and Theses by an authorized administrator of PDXScholar. Please contact us if we can make this document more accessible: pdxscholar@pdx.edu. 
CONTRIBUTIONS TO TUALATIN ETHNOGRAPHY:

SUBSISTENCE AND ETHNOBIOLOGY

by

Henry B. Zenk

A thesis submitted in partial fulfillment of the requirements for the degree of

\author{
MASTER OF ARTS \\ in \\ ANTHROPOLOGY
}

Portland State University

1976 
TO THE OFFICE OF GRADUATE STUDIES AND RESEARCH:

The members of the Committee approve the thesis of

Henry B. Zenk presented June 11, 1976.

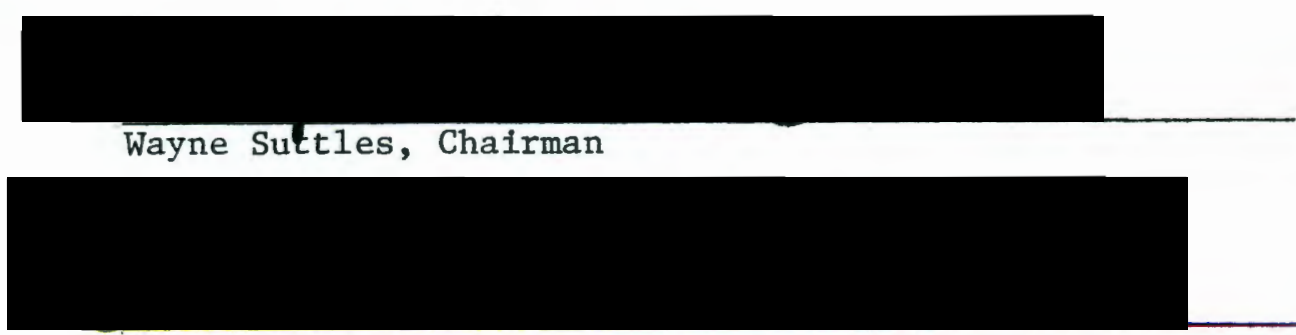

Thomas M. Newman

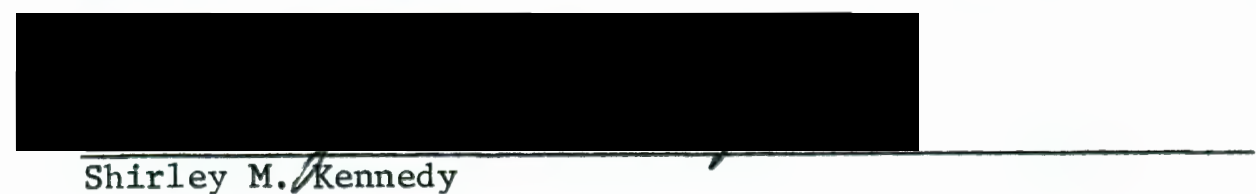

Shirley M. Kennedy

APPROVED:

Shirley M. Kennedy, Chairman, Department of Anthropology

Richprd B. Halley, Acting Dean, Gratyate Studies 
TABLE OF CONTENTS

PAGE

ACKNOWLEDGEMENTS

iii

LIST OF FIGURES

vii

CHAPTER

I

INTRODUCTION

1. The Tualatin-- General Identification . . . . . . 1

2. History and Sources . . . . . . . . . 6

2a. Historical Record

2b. Main Sources

3. Some Subsistence-Related Aspects of Socio-Political Organization . . . . . . . . . . . .

II SUBSISTENCE . . . . . . . . . . . . . 19

4. Habitat ................ 19

4a. General: The Willamette Valley at the Time of Early White Contact

4b. The Natural Character of Tualatin Country During Pre-Settlement and Early Settlement Times

5. General Subsistence Pattern; Regional Context . . 30

6. The Tualatin Subsistence Cycle . . . . . . . 37

6a. Territorial and Seasonal Availabity of Resources

6b. Calendar and Yearly Round

7. Regional Interrelationships: Sharing of Resources and Exchange of Subsistence Commodities . . . . 45

8. Some Major Subsistence Resources . . . . . . . 53 
8a. Activities and Technology Related to Harvest and Preparation of Some Major Resources

8b. The Salmon Resource-- A Problem Area in the Record on Kalapuyan Subsistence

9. Native Taxonomic Categories . . . . . . . 77

10. Flora and Fauna Named by Kalapuyan Informants . . . 79

10a. Plants ................. 79

10a-1. Plant Names, Plants More or Less Identified

10a-2. Unidentified or Questionably Identified Plants

10a-3. Yamhill Terms for Which no Corresponding Tualatin Terms Were Found

10a-4. Introduced Plants

10b. Mamma1s ..................

10b-1. More or Less Identified

10b-2. Identification Uncertain

10b-3. Yamhil1 Terms for Which No Corresponding Tualatin Terms Were Found

10b-4. Introduced Mammals

10c. Birds . . . . . . . . . . . . .

10c-1. More or Less Identified

10c-2. Identification Uncertain

10c-3. Yamh111 Terms for Which No Corresponding Tualatin Terms Were Found

10d. Fish and Other Aquatic Fauna . . . . . .

10d-1. More or Less Identified

10d-2. Identification Uncertain

10d-3. Yamhill Terms for Which No Corresponding Tualatin Terms Were Found

10e. Reptiles and Amphibians ...........

10e-1. More or Less Identified

10e-2. Identification Uncertain

10e-3. Yamhill Terms for Which No Corresponding Tualatin Terms Were Found 
PAGE

10f. Insects, Parasites, and Other Arthropoda . . 130 10f -1 . More or Less Identified 10f-2. Identification Uncertain 10f-3. Yamhill Terms for Which No Corresponding Tualatin Terms Were Found 10f -4 . Introduced Insects

10g. Miscellaneous or Unidentifiable Fauna . . . 136

10h. Supernatural Beings . ......... 136

IV OTHER CONTRIBUTIONS: TUALATIN WINTER-VILLAGE GROUPS . - 140

11. Houses and Settlement Pattern . . . . . . . 140

12. Winter-Village Groups . . . . . . . . . . 142

12a. More or Less Definitely Identified

12b. Village or Place Names: Information Insufficient to Identify Clearly

12c. Place Names, Erroneously Identified as Village Names in Hodge (1907) 
AN ABSTRACT OF THE THESIS OF Henry B. Zenk for the Master of Arts in Anthropology presented June 11, 1976.

Title: Contributions to Tualatin Ethnography: Subsistence and Ethnobiology .

APPROVED BY MEMBERS OF THE THESIS COMMITTEE:

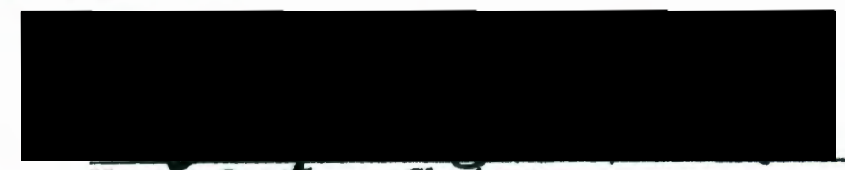

Wayne Sut les, Chairman

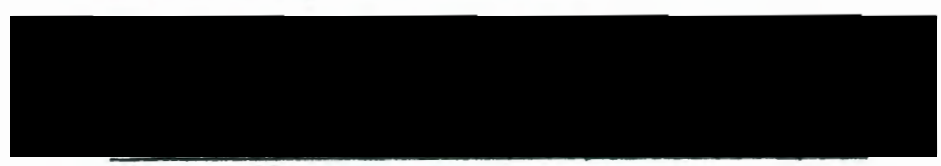

Thomas M. Newman

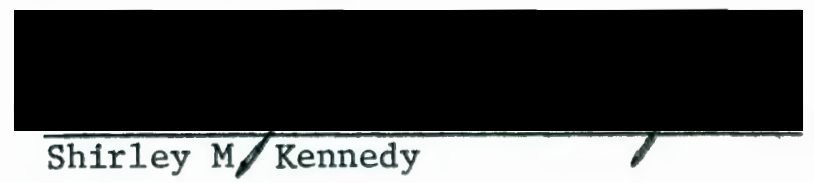

There is a considerable amount of unpublished source material on Kalapuyan ethnography. This consists primarily of manuscript field notes from three 1inguistically trained scholars: Albert S. Gatschet, who collected Kalapuyan Iinguistic and ethnographic data during a visit to Grand Ronde Reservation in 1877 , Leo J. Frachtenberg, who worked with a number of Kalapuyan informants from 1913 to 1915, and Melville Jacobs, who worked with the last surviving speakers of Kalapuyan languages during a number of sessions between 1928 and 1936. Data from these three authorities, plus other available data, reveal many details about aboriginal Kalapuyan life ("aboriginal" here referring to the period from 
around first White contact until removal to the reservation). Any attempt to reconstruct ethnographic descriptions of the aboriginal Kalapuyans should fully utilize these available data. I intend this thesis as a beginning effort toward that end.

It seemed to me that the ethnographic notes scattered through the Gatschet manuscripts, representing as they do the knowledge of informants who had reached adulthood under pre-reservation conditions, would prove particularly interesting in terms of ethnographic reconstruction. Thus, I selected the Tualatin Kalapuyans, the subject of Gatschet's main effort, as my own focus. In view of the quantity of data involved, I further restricted my scope to much less than an overall ethnographic description of the aboriginal Tualatin. I have concentrated upon two related aspects of that larger picture--subsistence and ethnobiology. Under the former, I consider aboriginal habitat, general subsistence economy, territorial and seasonal availability of subsistence resources, seasonal cycles involved in harvest of resources, subsistence-related aspects of regional interrelationships such as trade, and specific subsistence-related activities and practices. Under ethnobiology, I consider native knowledge and uses of plant and animal resources.

In Chapter IV, some additional ethnographic information unrelated to these two main areas is also presented concerning the identification and localization of Tualatin winter-village groups. 
CHAPTER I

INTRODUCT ION

\section{THE TUALATIN-- GENERAL IDENTIFICATION}

The name "Tualatin" refers to the aboriginal population which occupied the Tualatin River basin (Tualatin Plains and Wapato Lake near Gaston being the areas where winter settlements were concentrated), as well as the drainages of Chehalem Creek and the North Yamhill River, south to the main Yamhill River at Lafayette. The present form of the "tribal" name is one of a number of historically recorded variations upon the Tualatins' own name for themselves, a-tfa/lati, ${ }^{1}$ and/or upon somewhat variant forms of the same name recorded from other Kalapuyan dialects (e.g., Santiam an-twa'lati, Mary's River twa.'latya; additionally, Jacobs gives itwa'lati as the Clackamas Chinookan name for the Tualatin). No etymology has been discovered for this name.

Before the catastrophic declines suffered by the aboriginal populations of the area during the early historical period (the result, primarily, of epidemic diseases), the Tualatin lived in upwards of 15-20 winter village or hamlet groups (see sec. 12 for detailed consideration of data bearing on identification and localization of these groups). These local groups, though not bound together by any system of "tribal" organization, were socially and culturally very closely interrelated,

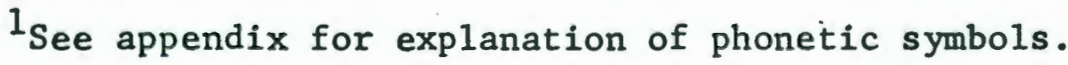




\section{ACKNOWLEDGEMENTS}

I wish to acknowledge my special appreciation to the following persons and parties for their help:

Wayne Suttles, for his support and encouragement and his role in securing copies of much of the manuscript material upon which this thesis is based; Yvonne Hajda, for her advice and support, particularly concerning phonological and linguistic matters; the Melville and Elizabeth Jacobs Foundation, whose furnishing of a small grant facilitated my access to the Melville Jacobs Collection; David French, for his valuable contributions to the ethnobiological sections; Robert Benson, who freely shared with me his considerable knowledge of cartography and local history; and Anita Malady, who generously contributed her own time to give essential assistance in the typing and proofreading. 
and, apparently, shared a definite sense of collective identity. The linguistic record associates a distinct dialect ("Tualatin") with this collection of local groups. This dialect, together with its fully mutually inte1ligible sister dialect, Yamhill (spoken in another loose but ethnically identifiable collection of villages, called ya'mil by the Tualatin as well as by the Yamhill themselves), formed one (the northern) of the three distinct languages (northern, central, and southern) of the Kalapuyan language family (or subfamily, according to Swadesh $Г 1965$ _ who lumps Kalapuyan with Takelma in his Takelman family).

Treaty documents (especially, Gibbs and Starling 1851 and Belden ca. 1855), plus what ethnographic data there are which seem to reflect an aboriginal conception of territorial limits (see sec. 7), permit the following general delimitation of the Tualatin in relation to neighboring groups.

To the north of the Tualatin, between Tualatin Plains and the big bend of the Columbia River, were the Athapascan-speaking Clatskanie (called $\underline{a}-\underline{z} a^{\prime}$ cxne $i$ by the Tualatin, according to Gatschet), a people seen as alien alongside the Chinookans and other Kalapuyans with whom the Tualatin had close ties, although there is no mention of hostile relationship between the two groups.

On the west, the territorial relationship which existed between the Tualatin and coast-dwelling Tillamook (whose country was called pa'pfan by the Tualatin) is rather unclear (see sec. 7); it is at least certain that the Tualatin took advantage of subsistence resources available in the Coast Range, and travelled to the coast on occasion.

To the south, the Yamhill and Tualatin territories met at the main 


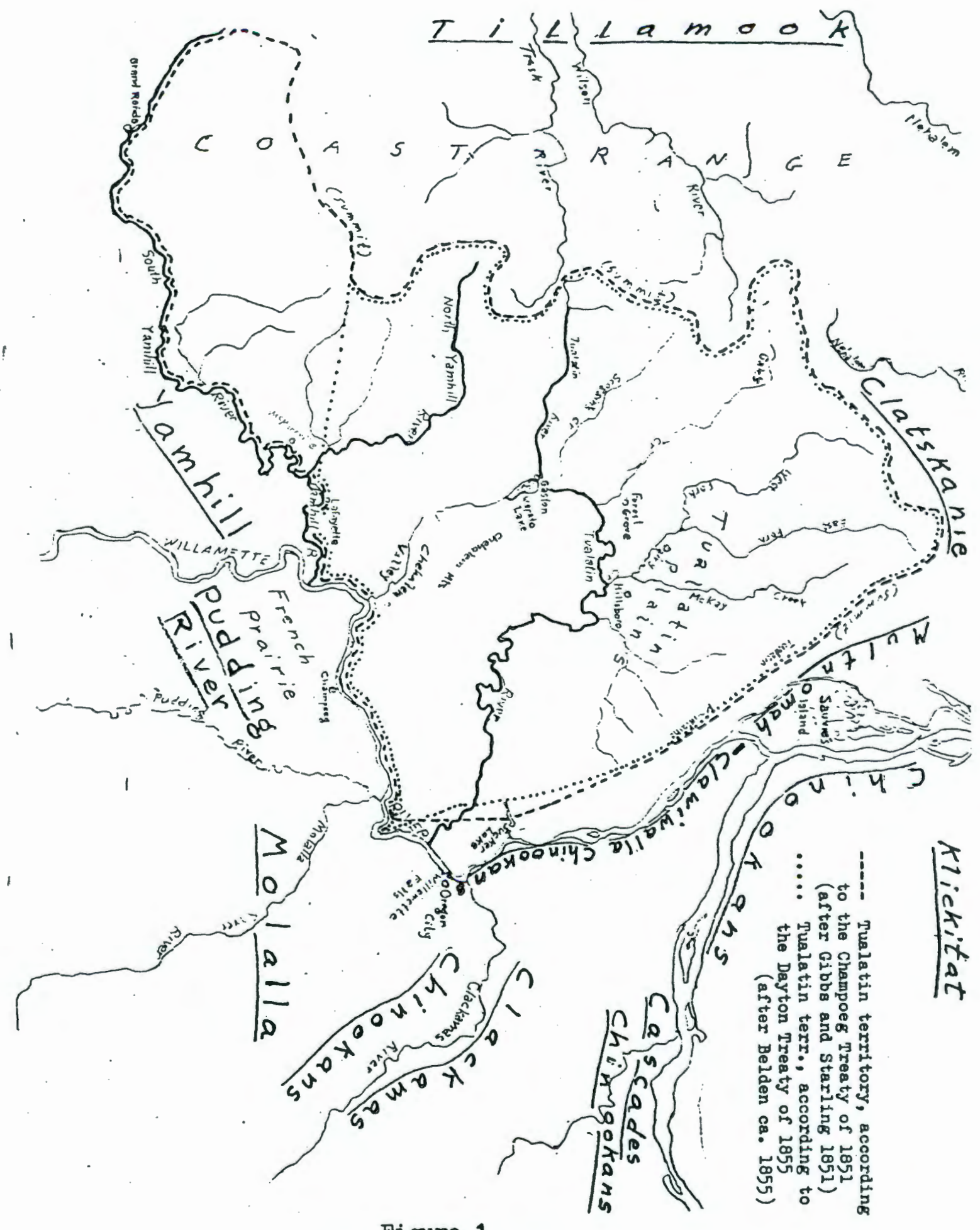

Figure 1

Tualatin territory 
Yamhi11 River; things are uncertain to the west of the forking of the North and South Yamhill Rivers, as the treaties disagree here (see map), and there are no relevant ethnographic data. The Tualatin and Yamhill were culturally as well as linguistically closely related, and seem to have shared a corresponding sense of mutual kinship.

To the south and east, across the Willamette River, in the French Prairie area, were the Pudding River or an-ha'nçiyuk people (Santiam dialect name, given by Jacobs), who spoke a dialect of the distinct central language of Kalapuyan. There was a village somewhere near Champoeg State Park, on the north bank, or possibly on both banks, of Willamette River (see Hussey 1967:17-18). While this village is mentioned in the Tualatin ethnographic material (Gatschet $[1877 \mathrm{a}: 269,282]$ giving ča/mpuik as the name of a "town" in the French Prairie area where Indians gathered to dig the root $\left.\mathrm{pu}^{\prime} \boldsymbol{X}_{\mathrm{ik}}\right)$, it is not mentioned as having been Tualatin-I thus speculate that it was ha'nčiyuk, unless, of course, it represents some undocumented entity.

On the east and northeast, going north from somewhere in the vicinity of the mouth of Tualatin River (according to the treaties, from a point a few miles up the Willamette from the mouth of the Tualatin; I found no ethnographic data concerning Tualatin interest or activity in this area), thence past Willamette Falls on the east to the "Sucker Lake" (Lake Oswego) area, and on northwest through the Tualatin Mountains, the Tualatin bordered on the Willamette Falls and lower Willamette-Sauvie's Island upper Chinookans. These Chinookan village groups, plus those located on the Columbia River in the vicinity of Vancouver, were collectively referred to by the Tualatin under the name a-fél. In the 
aboriginal political balance of the early historical period, these groups were notable as being the main sphere of influence of the powerful chief

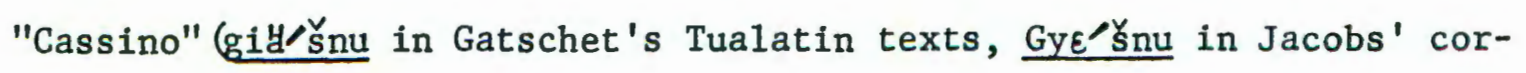
rected version of the latter).

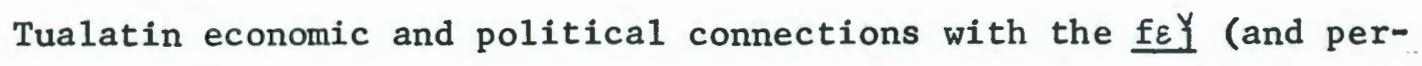
haps other Chinookans), manifested for example in marriages between chiefly Tualatin and $\underline{f} \underline{y}$ families, imparted a Chinookan influence to Tualatin society and culture. In fact, there is evidence (e.g. Smith 1901:255-258) that the Tualatin, together with Chinookans and northern Oregon coastal groups, were major participants in a regional network of economic and political interrelationships centered on the lower Columbia River. The most obvious mark of central participation in this network was flat-headedness as an invariable sign of free birth-- the Tualatin, Chinookans, and coastal groups including the Tillamook and Alsea-Yaquina flattened the heads of all free-born infants; flattening was apparently not universally practiced among central-1anguage-speaking Willamette Valley groups, and it faded away entirely farther south. Slave trading was an important economic activity of the major participants in this network. The main Tualatin role in such activity seems to have been to help supply slaves to the Chinookan trading centers such as that at Oregon City. The Tualatin often obtained slaves through trade with neighboring and distant slave-holding groups; also, the Tualatin themselves at least occasionally conducted slave-raiding expeditions into such areas as the southern Willamette Valley and the central Oregon coast. Almost all slaves were captives or descendents of captives, originally taken from distant groups and often traded widely through the area. 
Aside from such indications of Chinookan influence, what data there are on the Tualatin show many points of similarity with other Kalapuyans. "Chiefs," unlike their Chinookan counterparts, did not constitute a hereditary caste; chieftainship was inherited only in the sense that wealth was inherited. Slavery however was hereditary, so that slaves constituted the most definite social stratum. Aside from the slave-free distinction, the main social distinction was between wealthy or "good" people and common people; wealth could be achieved by the non-wealthy and lost by the wealthy, so that there was no absolute divide between these two social categories. Residence and marriage conformed to the general Kalapuyan pattern, with patrilocal residence and local exogamy usual, polygyny preferred, and marriage-payment transactions notably unbalanced in favor of the bride's family. Ceremonial and religious activity was centered upon the acquisition and display of guardian-spirit powers.

\section{HISTORY AND SOURCES}

The Tualatin are one of the better documented Kalapuyan divisions. In general outline, the record on the Tualatin mirrors that on the Ka1apuyans in general: a very few scattered early passing mentions from travellers, settlers, etc., comprising an unfortunately quite inadequate contemporaxy record of pre-reservation life, then, treaty and Indian Affairs documents, and finally, a considerable body of material, primarily linguistic but with some ethnographic information, dating from reservation and post-reservation times. The following sketch is intended to provide background information for the main body of this study 
and does not purport to be a well-rounded survey of these categories of sources.

\section{2a. Historical Record}

The Tualatins' linguistic and cultural next-of-kin, the Yamhill, receive notably earlier mention in the historical record than do the Tualatin themselves. Alexander Henry, while passing Willamette Falls in 1814 on a brief trip to the Northwest Company's trading establishment somewhere in the Champoeg-Newberg vicinity, met a party of seven "Yamhelas" leading a horse loaded with bags of "raw commass I sic_f". Surely, these Yamhills were on a trading expedition to the falls; three days later, while passing the falls again on the return trip, Henry met the same party, this time loaded with dried salmon (Henry in Coues 1897:812, 819). On the first meeting, Henry commented:

They seemed to be an ugly, ill-formed race, and four of them had some defect of the eyes. They were Yamhelas, who dwell in houses on Yellow River, a branch of the Willamette. They are great Rogues, but not very numerous. Those we met were wretchedly clothed in deerskins; their quivers were of deer's heads and necks. Their women had petticoats of fringed leather, like the Chinook women's cedar petticoats, but reaching only halfway down the thighs. They wore small round bonnets of wattap, with a peak three inches high. They were of short stature, and a1together the most miserable, wild, and rascally looking tribe I had seen this side of the Rocky mountains. (Henry in Coues $1897: 812$ )

The earliest reference to the Tualatin themselves that I am aware of (I must note, though, that I have not thoroughly covered the historical record) is in John Work's journal of a Hudson's Bay Company expedition led by him from Fort Vancouver to the Umpqua River and back, in 1834 (Work 1923). On the outbound journey, Work entered the Willamette Valley by way of Tualatin Plains ("Faladin Plain" in his spelling) and 
Wapato Lake, noting, while not far north of the latter, that "there are a good many Indians about here, which causes the deer to be so wild" (Work 1923:244). On the return trip, Work has a passing mention of the Tualatin which seems to reinforce the image, suggested by other, primarily ethnographic sources, that the Tualatin were predatory slave raiders. In the vicinity of "River Lauries" (Mary's River), Work visited with some local Indians to trade beaver, commenting that "They $I$ the Indians_ $T$. . inform us that 4 men of Lautaude Indians I ? T have been killed \& 3 children taken slaves a short time since, as they suppose by a party of Faladin or Yamhill Indians" (Work 1923:264).

This first definitely documented mention of the Tualatin post-dates the "fever and ague" or "intermittent fever" epidemics of 1830-33 (a1most certainly malaria, cf. Cook 1955, Boyd 1975), which are known to have virtually swept away the Chinookan populations of the lower Willamette-Vancouver area. Aside from a brief, rather vague mention in Gatschet's Tualatin notes ("ague" and "malaria" both being mentioned, along with smallpox and dietary changes, as causes of the decline of the Tualatin (Gatschet 1877a:235_/), I have no documentation of the impact of this series of epidemics upon the Tualatin. However, in view of the proximity of the Tualatin to the lower Willamette-Vancouver area of known maxiumum impact, plus the ideal habitat which Tualatin country, with its marshlands in close proximity to native population, must have afforded the native species of malaria-carrying mosquitos, it is a fair assumption that the Tualatin were hit very hard. The earliest estimate of Tualatin population that I was able to find is from 1849, "60 souls, 30 warriors", given by Robert Newell (1959:152)(this is the figure cited 
by Lane [1849]). Later figures are in line with Newe11's-- e.g., the Champoeg Treaty of 1851 shows 65 Tualatins; Grand Ronde Agency records, cited by Powel1 (1891:82), show 28 Tualatins in 1890 .

Estimation of lower-Columbia area aboriginal populations for preepidemic times seems fraught with difficulties-- e.g., while Mooney (cited in Taylor 1963:164), extrapolating from Lewis and Clark's population data, estimated that there were about 22,000 Chinookan speakers around 1780, Taylor (1963:165), extrapolating from early Hudson's Bay Company figures, offers 5,000 as a more nearly correct figure. In the latter case, I suspect that Mooney is too high and Taylor too low, but I do not wish to attempt to untangle the issues involved in evaluating these two estimates. Mooney's estimate for the Kalapuyans (including al1 Kalapuyan speaking groups), 3,000 for circa 1780, seems based on an incorrect reading of Lewis and Clark's data. Lewis and Clark do give a figure of 2,000 for the "Cal-lah-po-e-wah nation" (from which Mooney projected a figure of 3,000 for the period just preceding the smallpox epidemic presumed to have swept through the area about 1782), but they also refer to 10,600 "Shoshones" resident along the "Multnomah I Willamette_T river". (Thwaites $1905 \mathrm{Vol}$. 6:118-119). Interpretation of the latter reference is complicated by Lewis and Clark's apparently very vague notion of the geography of the Willamette area; they apparently thought that their "Multnomah" River drained a much vaster area of country than it really does. However, the fact that 3,000 of these "Shoshones" are mentioned as winter residents on the "Multnomah," and springsummer residents on streams heading east of the Cascades (e.g., the falls of the "Towannehiooks" I Deschutes_ $T$ River, a fishing place, being men- 
tioned), does seem to pin down at least part of this population to the Willamette Valley (I suspect that this particular 3,000 may have been Molallas). Lewis and Clark themselves apparently assumed some degree of linguistic and ethnic identity for all of the peoples to whom they applied the name "Shoshone;" however, in their reference to the Willamette area, at least, they seem to have merely equated "Shoshone" identity with vaguely inland-type culture. The same vague application of this name to inland dwellers crops up elsewhere in the earliest 1iterature on the area-- cf. Stuart $(1953: 48)$, where the name is applied to inhabitants of the general interior Willamette Valley; Henry in Coues (1897:794), where it is applied to some unidentified inland-dwelling group, possibly, Clatskanie Athapascans, observed on the south shore of the Columbia River below Oak Point; Ross (1849:117), where it is given as a derogatory generic designation for inland dwellers. Thus, I reason, Lewis and Clark's 10,600 "Shoshones" probably included Kalapuyans, at least central and southern Kalapuyans.

As my own contribution to the picture on local aboriginal populations, I offer a speculation on aboriginal Tualatin population, as follows.

Gatschet's Tualatin informants gave names of at least 17 winter village groups (16, disregarding one said to have been long extinct; see sec. 12a); additionally, some names (sec. 12b) are given which may have been group names but cannot be certainly identified as such. Taking 15-20 as an estimate of the number of Tualatin local groups extant, say, around 1812 (just before the first major direct impact of the Whites, but still close to the experience of informants interviewed by Gatschet 
in 1877), and further assuming an average population of 50 per winter village group (which, it seems to me, allows for variations in the sizes of different groups while yet conveying some sense of the sort of relatively dispersed population which I suspect must have characterized Kalapuyans as opposed to Chinookans and other fisher folk), we would have an estimate of 750-1,000 for the Tualatin. Following Mooney's reasoning (1928:13-14), and assuming that the smallpox epidemic of circa 1782 reduced Tualatin population by one-third to one-half, we would then have an estimate of somewhere between 1,000 and 2,000 Tualatins for circa 1780 .

In 1851, the surviving Tualatins, along with Molallas and other Kalapuyans, signed a treaty with the United States and were given a sma11 reservation encompassing Wapato Lake (a large part of the proceedings of this treaty, generally known as the Champoeg Treaty, have been published by Mackey $[1974: 85-125\lceil$; however, this treaty was not ratified by the Senate and the reservation defined by it did not stand. Finally, in 1856, after signing the Dayton Treaty (1855; Kappler 1904 Vo1. 2:665669), the Tualatin were removed from their homeland to Grand Ronde Reservation. The linguistic and ethnographic record on the Kalapuyans derives almost entirely from the following reservation and post-reservation periods. I consider the Tualatin portion of this record in some detail.

\section{2b. Main Sources}

In 1877, the Swiss-born, European-educated linguist and ethnographer Albert S. Gatschet, then at the beginning of his long employ as an ethnologist with the U.S. Government (Gatschet later joined the Bureau of American Ethnology, upon its founding in 1879), spent two months 
on the Grand Ronde Reservation collecting linguistic and ethnographic data from native survivors, especially Tualatin survivors. Gatschet's Tualatin effort is represented primarily by 402 pages of field notes (Gatschet 1877a) and a vocabulary list in Powell's first outline (Gatschet $1877 \mathrm{~b}$ ). Gatschet's main informants were Peter Kenoyer (Tualatin

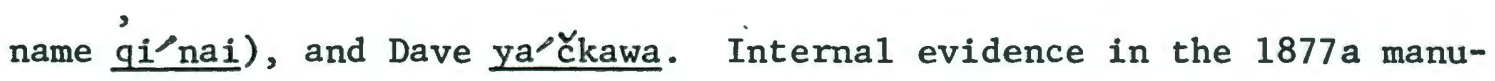
script indicates that Peter Kenoyer is responsible for almost all of the material up to p. 229, while Dave Yatchkawa is responsible for all or virtually all of the remaining pages plus notes and corrected or alternate linguistic forms scattered through the first section (these later additions are usually, but not always, identified as to source). No informants are identified in the $1877 \mathrm{~b}$ MS, but it seems 1ikely that this too is from one or the other if not from both of the same informants. ${ }^{1}$ Both of Gatschet's informants were, in Tualatin terms, men of substance: Peter (I prefer to use the first name in view of the fact that this informant's son, Louis Kenoyer, is also frequently referred to here) was the son of a prominent chief-- ga'yagax, the leading representative of the Tualatin in the 1851 and 1855 treaty negoti-

$1_{\text {Jacobs' following statement (in Jacobs, Gatschet, Frachtenberg }}$ 1945:155), regarding the informants contributing to the $1877 \mathrm{a}$ MS, is in partial error: "Notations in the $\mid 1877 a_{-} /$manuscript indicate... . that other Tualatin informants I besides Dave Yatchkawa and Peter Kenoyer_/ also worked with Dr. Gatschet; they were Emmy, Enimdi, Kemkid, and possibly others." The name "Emmy" is merely the English name of a woman named a'kemkit, "Kemkid," who apparently lived with Peter's family and did dictate two, or possibly three, of the texts appearing in the first half of the 1877a MS. The name "Enimde" appears in Frachtenberg's hand as a correction alongside Gatschet's unclear handwriting (1877a:85); I read Gatschet as writing "Emmie," noting that Gatschet has the same spelling elsewhere. I conclude that Jacobs has cited two names and one non-name of the same informant. 
ations. Dave Yatchkawa was himself a signer of the Dayton Treaty and was reputed to have been a powerful shaman.

Although, as Jacobs points out (in Jacobs, Gatschet, Frachtenberg 1945:155), ${ }^{1}$ the phonetic and translational accuracy of the Gatschet material falls considerably below modern standards, it does have the distinct advantage of deriving first hand from informants who participated fully in the aboriginal way of life. I depend fundamentally upon the Gatschet material for much of the ethnographic data upon which this study is based. Furthermore, the Gatschet material may turn out to have more linguistic value than Jacobs' evaluation of it would lead one to expect. This is certain at least as regards vocabulary (cf. sec. 10)-it would be well to have phonetically more accurate forms corresponding to those recorded by Gatschet, but unfortunately, the sole Tualatin informant available to later workers appears to have been considerably less fluent in Tualatin than were Gatschet's informants.

As far as I know, there was no further significant contribution to the record on the Tualatin until 1915, when Leo J. Frachtenberg visited the Yakima Reservation to work with the last known speaker of Tualatin, Peter Kenoyer's son Louis Kenoyer (Tualatin name paxawa'taš). According to Frachtenberg (National Anthropological Archives card catalogue, catalogue no. 4620), Louis, 47 at the time, had not heard or spoken Tualatin since he was 17 (this is probably when his father died, since Jacobs I ca. 1936a:preface_T commented that Louis had rarely heard

This reference is cited so frequently I hereafter abbreviate it only as Jacobs (1945). 
or used Tualatin since his father's death sometime in the 1880s). Louis was educated at boarding schools and had only a very dim knowledge of many aspects of aboriginal Tualatin culture (e.g., Jacobs $[$ 1945:155_ observed that Louis seemed completely unfamiliar with Tualatin mythology). Frachtenberg's work with Louis was apparently confined to corrections of Gatschet's previous work-- Frachtenberg took the Gatschet 1877a MS into the field with him, writing phonetic corrections of Gatschet's renderings directly into the original notebooks. Frachtenberg (ca. 1915) later prepared typescripts of Gatschet's texts, incorporating his own phonetic corrections and interpretations, along with grammatical notes; however, he never completed the project (most of the texts are not provided with translations, and spaces left for hand lettering of vowels are left blank). Much later, in 1936, Melville Jacobs took these Frachtenberg typescripts of Gatschet's texts back to Louis (still at Yakima Reservation), and began adding one more stratum of reworkings and phonetic corrections to them; once again, we are left with a half-finished project, this time due to Louis' death later in 1936, before Jacobs had had the chance to finish this along with other projects. The JacobsFrachtenberg reworking of the Gatschet texts, plus the remainder, consisting of Jacobs' phonetic reinterpretations of the Frachtenberg typescripts in conjunction with the original Gatschet notebooks, along with his attempts to provide translations from the Gatschet notebooks, were published by Jacobs (1945:155-198).

Besides his above-mentioned contribution to reworking the Gatschet material, Louis is also the source for texts and a grammatical sketch by DeAngulo and Freeland (1929) (however, DeAngulo and Freeland's char- 
acterization of Tualatin as a language far progressed towards complete analysis, "simple pure relational" in grammatical type, is dubious-- we may have here another intimation of Louis' limited fluency), and of an extended autobiographical text begun in 1929 by DeAngulo and Freeland and carried on to some length, but not to completion, by Jacobs (ca. 1936a). Louis must also be the source of the Tualatin portion of the Kalapuya Element List prepared by Jacobs (ca. 1936b) for Kroeber, though I found no background information on informants or other details relating to this list.

The death of Louis Kenoyer in 1936 would appear to mark the end of Tualatin culture.

\section{SOME SUBSISTENCE-RELATED ASPECTS OF SOCIO-POLITICAL ORGANIZATION}

The Kalapuyans apparently recognized group entities larger than the village group: a number of group names ("Tualatin," "Yamhi11," "Santiam," "Luckiamute," "Yoncalla," and others) designated clusters of dialectally and culturally identical or closely related villages or hamlets. However, the political significance of these entities is unclear. Due to the paucity of ethnographic observations from the period following first White presence in the area but preceding the "fever and ague" depopulation and later White settlement, it is not always possible to evaluate aboriginal features of socio-political organization in isolation from what must have been the considerable socio-political consequence of the latter events. E.g., there is some information (Frachtenberg 1914a:n.p., Jacobs ca. 1936b:128) that these group entities had "head chiefs;" however, it may well be that such "head chiefs" only 
arose in response to Whites' demands to deal with authoritative representatives of "tribes" in treaty negotiations. Gatschet's notes (1877a: 302) strongly suggest that Tualatin "chiefs," aboriginally, were merely the wealthiest members of their village groups; although particularly powerful personalities could have exerted influence beyond their immediate village group, it seems unlikely that there was any institutionalized "tribal" level of chiefly authority.

Question might arise as to whether these group entities existed at all in aboriginal times. Might Kalapuyans not have formed new group identities as their previously dispersed villages and hamlets were thrown together as a result of drastic depopulation and shrinkage of territorial base? However, there are grounds to suppose that these entities must have had some sort of aboriginal reality. In the first place, the native names corresponding to these entities appear consistently as the group names by which Kalapuyan informants themselves identified themselves (the name "Kalapuya," which is apparently of foreign origin, seldom appearing in the textual and ethnographic material). Also, the Gatschet Tualatin MSS, which represent the experience of informants who had reached adulthood under pre-reservation conditions, suggest that the various Tualatin village groups functioned as a unit at least for certain subsistence purposes. I consider Gatschet's data on this point in some detail.

As mentioned previously, Gatschet lists somewhere between 17 and 21 winter-village groups which were associated with the name "Tualatin." Gatschet's notes furthermore suggest that each winter-village group held its own rights of access to certain subsistence resources in cer- 
tain locales, but that the lot of these groups shared access to productive locales within a larger common territory. Moreover, this common territory was apparently rather well defined in relation to the territories of surrounding non-Tualatin native groups (at least as regards "title" or right, if not in the sense of being rigidly defended from outsiders; see sec. 7 for specific discussion of Tualatin territorial limits). The evidence for this picture consists of the following:

(1) It is stated (1877a:92) that areas where tarweeds grew were "allotted" to each "band" (winter-village group), plots within these "allotments" being in turn individually owned, but that hunting districts were not "allotted" (i.e., being, I infer, available in common to the various local groups).

(2) One of Gatschet's texts (1877a:151; also in Jacobs 1945:187188) indicates the general extent of Tualatin territory by reference to some specifically Tualatin hunting areas; this general territory is treated as a whole, especially in reference to the neighboring Yamhill and Clatskanie groups.

(3) A wapato harvest place on the north end of Wapato Lake is indicated to have been used by all of the Tualatin, "the whole tribe," a short text being added at this point which translates: "all of the Tualatin came together (assembled) I there_ $T$ in the fall of the year... I to gather wapato_/" (1877a:93).

It seems to me that such data invite some speculation on the relationship between habitational-adaptational factors and Tualatin (and general Kalapuyan) social organization.

The Kalapuyan subsistence base seems to have been diverse, re- 
quiring access to a variety of riverine and upland and lowland habitats (see sec. 6a). Thus, winter-village groups were perhaps relatively sma11, with each necessarily having access to a comparatively large territory. Therefore, the loose organization of Kalapuyan local groups into larger dialectal-ethnic units (the specific organizational structure of which is, of course, unknown) could have had an adaptational significance: such a form of organization would have provided a territory large and diverse enough to offer each local group sufficient access to an adequate range of subsistence resources, but at the same time it would have kept population suitably dispersed by preserving the separate existence of sma11 local groups. The treaty territories indicated for the Kalapuyans seem to bear out the possibility that this was an aboriginal pattern: each "tribe" or "band" elsewhere documented to have probably been a dialectal-ethnic entity seems to occupy its own valley or basin formed by one of the larger tributaries of the Willamette River; each such major valley offered a range of riverine, lowland, and upland types of habitat. 
CHAPTER II

SUBSISTENCE

4. HABITAT

4a. General: the Willamette Valley at the Time of Early White Contact To provide background for sec. $4 \mathrm{~b}$, in which I specifically consider the Tualatin portion of the valley, I present some general information here on the natural character of the Willamette Valley at the time of the first White contact and settlement.

Such information is extensive, and falls into three main categories: (1) first-hand observations by early travellers and settlers, (2) the records of the first federal land survey of the Willamette Valley, undertaken in the 1850s (available at the U.S. Bureau of Land Management, Oregon State Office, Portland), (3) recent ecologically-oriented research. Of these, category (2), in particular, has yielded a great deal of useful data-- see the reconstructions of the native vegetation of portions of the middle and upper Willamette Valley, circa early 1850s, by Johannessen, et al. (1971) and Habeck (1961). The following general account, though it makes some use of Habeck's contribution, depends primarily upon category (1).

Descriptions of the Willamette Valley given by early White travellers and settlers indicate a diversified landscape, with prairie, oak and fir savanna, patches of oak or evergreen timber, and heavily timbered riverbanks and hills. Comments to the effect that the area was 
exceptional in its general pleasantness and plentiful game are not uncommon. Some of the more common plants of the region noted by early observers include: oak (Quercus garryana), fir (mostly Douglas fir, Pseudotsuga menziesii), "pine" (Douglas fir and/or ponderosa pine, Pinus ponderosa), western hemlock (Tsuga heterophylla), western red cedar (Thuja plicata), alder (Alnus oregana), big-leaf maple (Acer macrophyllum), vine maple (Acer circinatum), Oregon ash (Fraxinus latifolia), hazel (Corylus cornuta), wild cherry (Prunus spp.), madrone (Arbutus menziesii), willow (Salix spp.), cascara (Rhamnus purshiana), crabapple (Pyrus diversifolia), dogwood (Cornus nuttallii), elderberry (Sambucus spp.), ninebark (Physocarpus capitatus), yew (Taxus brevifolia), wild rose (Rosa spp.), camas (Camassia spp.), brake fern (Pteridium aquilinum), blackberry (Rubus vitifolius), currants (Ribes spp.), "grasses," etc. (cf. Henry in Coues 1897:815-817; Franchere 1954:166; Douglas 1904-05 Pt. 3:78-82, 1959:142; Habeck 1961:67-77). Among common animal species, early observers noted deer in great abundance (especially, the native subspecies of white-tailed deer, Odocoileus virginianus leucurus, now reduced to a very small population inhabiting the lower Columbia River, but formerly abundant in the low hills and on the valley floors and river bottoms of the Willamette Valley; also, black-tailed deer, 0 . hemionus columbianus), elk (formerly abundant in the open country of the Willamette Valley as well as in the mountainous areas to which it is now restricted), black or brown bear (Euarctos americanus), grizzly bears, mountain lions, wolves and coyotes (both abundant), grey foxes Urocyon cinereoargenteus; red foxes, now abundant in the Valley, are apparently introduced), rabbits, squirrels, beavers, swans, ducks and 
geese (in great abundance during migration seasons), turkey vultures, grouse, hawks and eagles, etc. (see Henry in Coues 1897:816-817; Douglas 1904-05 Pt. 3:140, 216; Wilkes 1845 Vo1. 4:348; C1yman 1960:117-126, 131-147, 152-158; Bailey 1936:e.g. 82-83, 87-88, 90-91). Certain ear1y writers (Henry in Coues 1897:811; Ross 1849:235) comment that salmon were unavailable upstream from Willamette Falls. This was not so; e.g., Wilkes (1845 Vol. 4:344-345) has an eyewitness account of salmon energetically leaping the falls-- indeed, there was a major Indian salmon fishery there. However, the extent of the aboriginal salmon resource above the falls is uncertain; during seasonal low flow conditions there was probably no escapement of salmon over the falls-- the main escapement was probably by the spring chinook run, which was represented in quantity only in the main Willamette River itself and in its larger tributaries heading in the Cascades (see sec. $8 \mathrm{~b}$ for discussion of these matters).

The data provided by early descriptions of the Willamette Valley suggest the following somewhat more detailed picture: the Willamette River and its main tributaries were lined by dense timber (one account, that of Palmer $\Gamma 1847: 99$ T indicates that the belt of timber lining the Willamette River varied in width from between one-fourth and three miles); the water levels of the rivers were subject to dramatic seasonal fluctuation and often inundated the low-1ying areas beyond their banks; marshes and smal1 lakes were abundant; away from the belts of timber lining the main streams, much of the valley was open and diversified in character, with extensive tracts of prairie and oak (or oak-fir) savanna alternating with groves or small forests of oak and/or fir; 
the higher hills and surrounding mountains were mostly heavily timbered, with oak savannas and forests predominating in some of the hills and coniferous forests predominating at the higher elevations.

The diversified character of the Willamette Valley landscape (see Habeck Г1961_/ for a detailed delineation of vegetation types and their distributions in the old valley) may have caused a higher faunal population density and species diversity than would have been present were the area to have been allowed to develop its climatic climax (probably closed coniferous forest). This possibility is suggested by the ecological "principle of edges," which indicates that border areas (called ecotones) between distinct vegetation types as a rule support more species of plants and animals, and denser populations, than do either of the areas they separate (Clark 1954:412). I advance this reasoning only as a suggestion. However, whatever may have been the extent and importance of ecotonal areas in the old valley ecology, the significance of the extensive tracts of open country to Kalapuyan subsistence cannot be doubted. E.g., the oak savannas and prairies provided extensive areas of habitat favorable to at least four important Kalapuyan food plants: tarweed (Madia sp.), which grew on dry prairies, camas, which grew on wet prairies, hazel, which grew in dry semi-open or brushy areas, and the oaks themselves, which provided acorns.

It is now well known that these extensive tracts of prairie and savanna noted by early travellers and settlers were the direct result of frequent fires deliberately set by the local Indians. Following are some early travellers' and settlers' comments upon this practice (for some additional such comments, see Johannessen, et al. 1971). 
The early settler Jesse Applegate, writing of his boyhood experiences in the 1840s near Dallas, cites one reason why the prairies were burned:

It was a custom of these Indians, late in the autumn, after the wild wheat, Lamoro sappolil I Chinook Jargon; lamoro or lamolo 'wild,' sappolil 'flour, wheat'_/, was fairly ripe, to burn off the whole country. The grass would burn away and leave the sappolil standing, with the pods well dried and bursting. Then the squaws, both young and old, would go with their baskets and bats and gather in the grain. The Lamoro sappolil we now know as tar-weed (Applegate 1930:178-179).

The Wilkes expedition, in the Yamhill River area in 1841, gives similar information:

This part of the Willamette Valley is a prolonged level, of miles in extent, circumscribed by the woods, which have the appearance of being attended to and kept free from undergrowth. This is difficult to account for, except through the agency of fire destroying the seeds. The Indians are in the habit of burning the country yearly, in September, for the purpose of drying and procuring the seeds of the Sunflower I probably, tarweed, Madia spp., although other species of the sunflower family may have been harvested in like manner $T$, which they are thus enabled to gather with more ease, and which form a large portion of their food. That this is the case appears more probable from the fact that since the whites have had possession of the country, the undergrowth is coming up rapidly in places (Wilkes 1845 Vol. 4:358).

David Douglas, travelling through an area some distance south of the

Yamhill River during the later part of September 1826, cites some ad-

ditional possible reasons why the prairies were burned.

- . the custom of burning the soil is highly unfavorable to botanizing. This plan prevails everywhere, though the natives vary in their accounts of the reason for which it is done, some saying that it is in order to compel the deer to feed in the unburnt spots, where they are easily detected and killed; others, that the object is, to enable them to find wild honey I probably, wasp larvae, honey bees not being native; see sec. 10f-1, 非(20)_/ and grasshoppers, both of which serve for their winter food (Douglas 1904-05 Pt. 3:78-79).

Douglas' observations as he continued south through the valley 
during this trip also give an idea of the extensiveness of the areas burned. On September 30, he noted "most parts of the country burned; only on little patches in the valleys and on the flats near the low hills that verdure is to be seen." Next day, "country same as yesterday, rich, but not yet a vestige of green herbage; all burned except in the deep ravines." On October 5, he again noted the country being burnt, "like the whole of the country I have passed through;" on October 6, he writes that his feet are very sore from walking over the burned stumps of low brushwood and strong grasses; on October 8 , "we are just living from hand to mouth," "all the hunters observe that the animals are very scarce and those shy in consequence of the country being burned." (Douglas $1959: 214-217$ ).

For a reference to large-scale use of fire in western Oregon outside of the Willamette Valley, see the quote from Riddle, sec. 8a, 非(3).

In summary, we may conclude that the annual burning of the prairies by Kalapuyans was a major factor both in the ecology of the presettlement Willamette Valley and in Kalapuyan subsistence. One way of indicating the significance of the use of fire might be to label it an adaptive complex: on the one hand, it formed an integral part of specific subsistence activities, especially in the gathering of tarweed seeds; additionally, it maintained the existence of large tracts of prairie and oak savanna and probably increased the extent of ecotonal areas in the valley, consequences likely of great significance to the whole pattern of Kalapuyan subsistence. A study of tree growth rings, in the McDonald experimental forest near Corvallis, suggests that this practice has been going on for some time. 
Ring growth studies in stumps reveal that this country was frequently burned for at least 296 years or since 1647. Fires have not been so severe nor so frequent since 1848 , as suggested by the presence of large number of trees of the 90 -year age class (Sprague and Hansen 1946:89-98).

4b. The Natural Character of Tualatin Country During Pre-Settlement and Early Settlement Times

It would be possible to follow Habeck's lead here (Habeck 1961), making intensive use of the federal land survey records (especia1ly the original field notebooks) to draw a detailed map of Tualatin-country natural areas, circa the $1850 \mathrm{~s}$. I have not attempted to do this, but I do offer at least a beginning towards such a map. The survey records include sketches of each township surveyed; these sketches show natural features such as stream courses, marshes, and prairies, and they additiona1ly have scattered notes indicating general character of vegetation or soil characterizing different locales. The accompanying map summarizes information available from these sketches; natural areas are not we11 defined as to type, nor so exactly delimited as in Habeck's study, but at least a rough picture is given of notable natural features and vegetation-types.

I have not fully explored the possibility of floral and faunal variations between the Tualatin and other areas of the Willamette Val1ey. There does seem to have been a significant north-south gradient within the valley in the ratio of relatively open to relatively forested area. As a traveller went south through the old valley, the prairie areas became more extensive, the ratio of oak to fir timber increased (Palmer 1847:95), with large timber of any kind (at least that adequate for fencing and building, according to Hines $[$ 1881:332 $/$ ) 


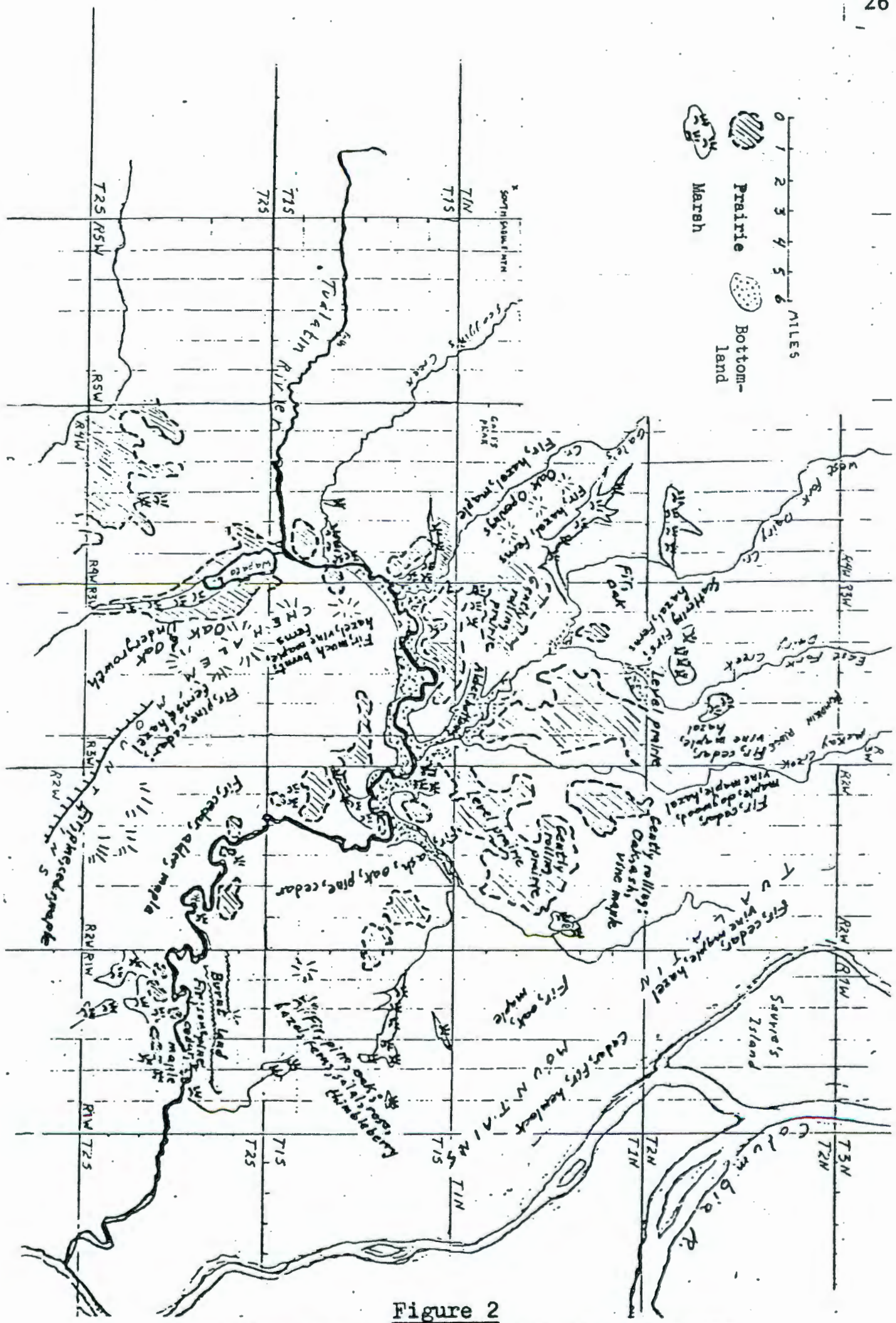

$\frac{\text { Figure }}{\text { getation and natural areas }}$ Tualatin-basin vegetation and 
ultimately becoming scarce on the floors of the upper valley. By contrast, Tualatin country occupied the northern extreme of this gradient, with less extensive, relatively more discontinuous prairie areas, and relatively more fir timber. I do not venture to speculate on the impact that such habitational variations might have had upon Tualatin as opposed to general Kalapuyan subsistence. There is some evidence (see sec. 5) that the Tualatin and Yamhill depended relatively more upon large-game hunting than did other Kalapuyan groups. If this was so, the question arises (but I make no attempt to answer it here) as to whether, due to habitational factors, large game was relatively more available to the Tualatin and Yamhill than it was to other Kalapuyans.

There is less documentation of large-scale aboriginal use of fire in the Tualatin area than there is for other parts of the Willamette Valley. I found two direct references to use of fire in the Gatschet MSS. One is in connection with the name of one of the Tualatin wintervillage groups, ̌a-pu'ngatpi Isee sec. 12a, 非(12)_T. Dave Yatchkawa (Gatschet 1877a:289) explains the etymology of this name, probably questionably, in terms of a group or place name ga'tpi, plus the expression pun nim·ai 'make their fires' (pun 'make, do,' nim-mai 'theirfire'), referring to the setting of fires to "drive out" deer. The other reference is in connection with the harvesting of tarweeds; it is noted (1877a:92) that the areas where tarweeds grew were set afire about August for the seed harvest. I came across one other reference to Tualatin use of fire. Dickson (1946:156), in her M. A. thesis entitled "Food Plants of Western Oregon Indians," states that "the Tualatin prairie near Portland was set afire every year to make it easier 
to gather these I tarweed_/ seeds." Unfortunately (and this is a frequent problem with this source), Dickson gives no documentation for this information; it is possible that it derives from an Indian informant, as her thesis includes information gleaned from five Indian informants (including "Mr. Mose Hudson IJohn Hudson, Jacobs' old Santiam informant_T of the Calapooya tribe," and "Mrs. Hoxie Simmons of the Molalla tribe").

Some direct observations on the natural character of Tualatin country during pre-settlement and earliest settlement times are available. The best of which I am aware are those by Clyman (1960:120-123, 132), Palmer (1847:90-91), and Work (1923:240-246). I consider the latter two in some detail.

John Work, describing his passage over the Tualatin Mountains and onto Tualatin Plains, in 1834, has the following description (commencing with a few comments on the rough, wooded country in the mountains, and continuing with an account of Tualatin Plains):

The soil I of the Tualatin Mountains_ $T$ is composed of a thick strata of dark vegetable mould perhaps not over 6 or 8 inches deep, over a bed of reddish tile. . . . It is not thickly wooded with timber but overgrown with underwood. The trees principally pine \& cedar and of a pretty large size. On reaching the plains some oak of a middling size fringe the edges of the woods. There are also some ash \& other trees. The country on getting out of the woods has a beautiful appearance. It is a continuation of plains which commence here and continue on to the Southward, separated by narrow strips of timber, bounded to the east by the strip of woodland which occupy the banks of the willamet I sic_I; and to the westward by the woods which occupy the base of the Killymaux I Tillamook / Mountain $I=$ the Coast Range $T$.

The soil is a rich blackish mould covered (but not with a close thick sward) with grass \& other plants, among which are considerable quantities of strawberry plants, now well furnished with fine fruit. Not a stone \& scarcely a shrub to interrupt the progress of the plough which might be employed 
in many places with little more difficulty than in a stubble field.

The country here though termed Plain from being clear of wood, is not a dead flat but composed of portions of level land with gently rising grounds. Portions of the flat lands are springey. Here the soil inclines to be clayey. The vegetation is not rank, yet it yields a great deal of pasture. This first plain I i.e., prairie / may be about three times the size of the clear ground about Fort Vancouver, and about 170 horses have been feeding upon it for the two last months, and there would still be grass enough for them for the rest of the summer. This Plain is never overflowed; the most Northern fork of the Faldin I Tualatin_ is a little distance further on to the Southward. It is not far but through a woody country, to the banks of the Columbia in a N. N. W. direction.

The open country here is of an irregular form, as points of woods jut out into the plains from both sides. . . The open ground here may be about 3 or 4 miles wide from E. S. E. to W. N. W. (Work 1923:241-242).

Further on in the same trip, Work passed Wapato Lake on his way

to Chehalem Valley.

After leaving the river where we slept last night I probably, Scoggin's Creek /, the road lay through a point of woods, and two small plains of fine rich soil, but subject to be under water at times during the rainy season. Then over a few hills mostly covered with wood and bushes, and along an_extensive plain of rich soil with a kind of swamp or lake I Wapato Lake_/ running all along the West side of it. Parts of this plain are subject to be partially inundated. Before reaching the southern extremity we struck across to the Eastward over a portion of low hilly country covered with bushes and some trees, principally oak to the head of the fine plain I probably, Chehalem Valley_/ where we are encamped; which is some miles in length and breadth, composed of a rich soil covered with fine pasture; the lower part of it subject to be overflowed or rather covered with water in the rainy season. (Work 1923:245-246).

It is notable that Wapato Lake was a shallow, marshy body of water, subject to dramatic fluctuation in response to the amount of water running in upper Tualatin River (which, when particularly high, could make the lake discharge through its upstream end into Chehalem Creek), and that it contained large quantities of wapato (Sagittaria latifolia) (United States Survey 1852:129-132, 184; Gatschet 1877a:282). 
Joel Palmer, writing in 1845, noted that "Quality Plains" Г Tua1atin or Tuality Plains_ $/$ was 25 miles in length, "alternately rolling: prairies and timber, surrounded by heavy growths of firs, many of which rise to the height of two hundred and fifty feet," also that the "bottoms" along the Tualatin River were heavily timbered (Palmer 1847:9091). Palmer's account becomes rather more detailed as it takes in the southern portion of Tualatin country: the North Yamhill River, upon emerging from the Coast Range, ran through a valley 12 miles wide approximately, bearing groves of oak and other timber, occasional "bottom prairies," and numerous "spring branches;" the range of hills dividing the North and South Yamhill Rivers was covered with grass, numerous fir-lined springs, groves of oak, alder, and willow, and graded on the west into a country of "fern openings" and timber groves, the latter in turn grading into the heavily timbered Coast Range; the South Yamhill River, upon emerging from the mountains, ran for its first ten miles through dense fir timber of large growth, then into a 15 mile wide valley, well timbered along the river, with grassy prairie (diversified with occasional groves of trees) lying one-fourth mile back on the average from the timber; Palmer incidentally remarked that the "lower bottoms" of the South Yamhill "yield an abundant supply of the Camas " (Palmer 1847:90-91).

\section{GENERAL SUBSISTENCE PATTERN; REGIONAL CONTEXT}

My overall impression of the available data on Tualatin as well as general Kalapuyan subsistence is that, coincident with the high floristic and faunistic diversity which characterized the aboriginal 
Willamette Valley, Kalapuyan subsistence was likewise diversified. The major categories of resources which made up the Kalapuyan subsistence base may be summarized as follows:

(1) Vegetable (especially, camas, wapato, tarweed seeds, haze1nuts, dried berries, acorns).

(2) Fisheries (salmon, steelhead, lamprey eels, non-anadromous species).

(3) Large game (white-tailed and black-tailed deer, elk).

(4) Small and medium-sized game (small and medium-sized mammals of all kinds, waterfowl, other birds).

(5) Insects (grasshoppers, caterpillars, yellowjacket larvae).

The examples listed for each category are only those resources mentioned particularly frequently or mentioned as being particularly important. More detailed consideration of the total range of resources representing these five categories is given in the sections on ethnobiology (secs. 10a-10f). Some indication of general limits within this total range is in order, however.

I found no mention of any insect resources other than those noted above. Apparently, reptiles and amphibians were not utilized in subsistence-- avoidance of 1 izards and snakes is noted for the Tualatin (Gatschet 1877a:343); avoidance of frogs, 1izards, and snakes for the Santiam (Jacobs 1928-36 非4:3). Grizzlies, coyotes, and foxes (Gatschet has "red fox," but grey fox is probably correct I see sec. 10b1, 非(20)_T) were hunted and killed by the Tualatin, but not eaten, it being further noted that the grizzly was not eaten "because he ate people" (Gatschet 1877a:168, 343). The Santiam likewise did not eat 
grizzlies, the same reason for avoidance being given (Jacobs 1945:23). It seems fair to speculate that avoidance of coyotes was similarly motivated; coyotes often scavenge for food and, indeed, are not averse to eating human remains when such are available. Might similar cnnsiderations then apply to other scavengers?-- e.g. ravens, birds of prey, vultures, wolves; I have found no indication that these animals were eaten by Kalapuyans. Aside from such avoidances, it is clear that Ka1apuyans took advantage of a wide range of vegetable and animal resources. I do not think we can expect to exactly evaluate the relative importance of the major resource categories outlined here. What historical references there are in this connection indicate that category (1), vegetable resources, was the category of single greatest importance in general Kalapuyan subsistence. The earliest such reference that I am aware of is an entry in Alexander Henry's journal, dated December 25, 1813, referring to a communication from William Henry, who was in charge of the Northwest Company establishment in the Willamette Valley (located in the French Prairie area). This states:

The news from that quarter I Willamette Valley_ $T$ is that beavers are numerous, but the natives, who are also very numerous, will not hunt them; their sole employment is digging roots, such as commass I sic_l and waptoe I sic_l, and stealing beavers from traps when opportunity offers (Henry in Coues 1897: 777).

Alexander Henry later himself made a short trip to the Northwest Company's Willamette Valley establishment, and made some observations on the "natives," "called Calipuyowes." Among other things, Henry noted that "deer are numerous $I$ in the Willamette Valley_ $T$, but roots of various kinds, which abound, constitute their I the Calipuyowes' $T$ principal food," also that "these people preserve their comass I sic_ 
much better than any others; they make it up in cakes of about 10 pounds' weight, three inches thick, in which state it keeps fresh and moist" (Henry in Coues 1897:814-815). Later historical references also point to such a primary dependence upon vegetable resources. However, I hesitate to depend much upon such later references, since virtually all date from the final period of Kalapuyan aboriginal life, when the impact of White settlement was drastically affecting the very subsistence base as well as the aboriginal economic system. It is apparent that during this final period, availability of native resources was diminishing-- Whites were busily hunting the game, clearing and plowing the land, turning their hogs loose to feed on camas and wapato, etc.-- and that the surviving Kalapuyans were becoming integrated into the economic system of the dominant society, continuing to subsist on native resources, particularly camas and whatever other vegetable resources could still be found in quantity in some areas, but depending more and more upon provisions purchased with earnings from farm and domestic labor. On the whole, Kalapuyan informants' statements also suggest that category (1) was of single greatest importance in Kalapuyan subsistence. Within this category, such information further suggests that camas was of major importance, both as a staple and as an article of trade. Additionally, there is some indication that wapato (in addition to camas) was of major importance in Tualatin subsistence. Beyond this, available information permits the following generalizations about the relative importances of the other major resource categories.

Category (5) (insects) was probably of limited importance. Indeed, I find no evidence that the Tualatin used insects at all, though in 
view of the sketchiness of the total record I do not think that this is enough to indicate that the Tualatin were distinct from other Kalapuyans in this respect. For other Kalapuyans, caterpillars and yellowjacket larvae are mentioned as delicacies, the former furthermore being noted not to have been available in quantity every season I see sec. 10f, 非(3), (20)_T. Little information beyond mere mention of use is offered regarding grasshoppers, although it seems likely that large quantities of grasshoppers could have been collected following the annual prairie fires.

A later section (sec. $8 \mathrm{~b}$ ) indicates that the Kalapuyans, the Tualatin in particular, probably did not have direct access to nearly as substantial a fisheries resource as was available to coastal and Columbia River groups. However, trade and fishing expeditions to nearby coastal tributaries likely made this category more important within overall Kalapuyan subsistence than it would otherwise have been. Small and medium-sized game was abundant in the Willamette Valley and must have been extensively exploited by all Kalapuyans. The picture regarding large game is hazier, a couple of statements of informants as well as some early historical observations suggesting that large game occupied a rather minor part of the total subsistence picture, at least for central Kalapuyans. Central Kalapuyans were surely proficient enough as large game hunters-- question arises only in regard to the relative importance of large game in overal1 subsistence. On the other hand, there is some evidence, though again sketchy, that large game was of relatively greater importance in Tualatin and Yamhill subsistence. 
I summarize some of the data upon which the above generalizations are based. These data primarily reflect the regional distinctiveness of Kalapuyan subsistence, i.e., the variations in resource emphasis particularly distinguishing Kalapuyans from neighboring non-Kalapuyans, rather than commenting directly upon absolute importance of individual resources .

Eustace Howard, one of Jacobs' two Santiam informants, stated that camas was "a11 over" in the old Santiam country, but that there was little if any camas in any other (presumably, non-Kalapuyan) "country," furthermore that Coyote caused berries, camas, and hazelnuts to be abundantly available to the Santiam but not to the Clackamas (but, as we might expect, also making salmon available in abundance to the latter but not to the Santiam) (Jacobs 1928-36 非83:133, 137). Gatschet's Tualatin informant Dave Yatchkawa similarly contrasted the "Kalapuya" (presumably including the Tualatin; Dave elsewhere uses the name in its generic sense), whom he characterized as living on prairies and eating berries, hazelnuts, camas, and "wild potatoes" (wapato), with the afe-Y (lower Willamette-Vancouver Chinookans), whom he characterized as living on the water, having canoes, eating fish, and "talking differently" (Gatschet 1877a:229). Eustace Howard's wife (and Jacobs' Clackamas informant), Victoria Howard, remarked on the regional exchanges of commodities which took place at Willamette Falls, a center of aboriginal commerce. According to her, the Willamette River Kalapuyans characteristically brought camas and other (unmentioned) things, the Molalla brought smoke-dried meat, and the Tualatin brought "wild potatoes" (wapato), and smoke-dried deer meat (gotten from their hunting area near 
Newberg, she comments), to exchange with the Clackamas for smoke-dried fish, smoke-dried eels, and pounded dried salmon (Jacobs ca. 1929-30: $\mathrm{n} \cdot \mathrm{p}$.

These sketchy remarks of Mrs. Howard's seem to me to constitute a particularly important bit of evidence regarding regional variations in subsistence patterns. Various bits and pieces of evidence reinforce this conclusion. It is about as clear as can be under the circumstances that Molalla subsistence was primarily based upon hunting. This is indicated by a number of informants' statements and historical observations which agree in suggesting, as Mrs. Howard stated, that "all the Molalla people did was hunt!"; Eustace (Jacobs 1928-36 非83:14, 非84:10) adds the information that mountain huckleberries constituted another notable Molalla trade article. The importance of camas in the subsistence and trading activity of central Kalapuyans seems borne out by the few available early historical observations on Kalapuyan subsistence (especially, Henry's observations cited above and in sec. 2a); Eustace, again (Jacobs 1928-36 非84:10), adds a bit of detail-- he thought that the Santiam might have brought hazelnuts and buckskins, along with camas and other things, to the falls to trade. That wapato must have been a Tualatin staple is suggested by Gatschet's account of the Tualatin yearly round (sec. $6 \mathrm{~b})$, which implies that the wapato harvest was an integral part of the annual cycle of Tualatin subsistence activity. Things seem hazier with regard to the relative importance of large game hunting in Tualatin as opposed to central Kalapuyan subsistence. There is a bit of evidence relating to the Yamhili, which (assuming that Tualatin and Yamhill subsistence patterns were similar, parallel- 
ing the other close resemblances between these two groups), might be taken to corroborate Mrs. Howard's implication that the Tualatin were rather notable large-game hunters, perhaps more so than central Ka1apuyans. This consists of one of Laughlin's (1943:220-229) findings in his excavation of two late prehistoric-early historic burial and campsite (?) mounds, south of Main Yamhill River (likely, historic Yamhil1 country). Laughlin noted that these sites contained large amounts of deer and elk bone fragments as well as bone and antler artifacts, especially as compared to what he had previously found in his centralvalley sites. The only statement I could find to corroborate the tenuous conclusion (suggested primarily by a few early historical observations) that the central Kalapuyans were relatively less notable large game hunters, is again from Mrs. Howard, who commented that Eustace's mother (a Santiam) once remarked that the Santiam hunted deer only occasionally, generally sharing a kill among villagers for immediate use rather than preserving the meat.

\section{THE TUALATIN SUBSISTENCE CYCLE}

\section{6a. Territorial and Seasonal Availability of Resources}

My information is too limited to offer a complete picture of the annual Tualatin subsistence cycle or a complete list of specific 1ocales visited for resources. However, by considering the resources listed in sec. 5 in the light of general botanic and zoologic knowledge, it is at least possible to approximately determine when and where certain resources would have been available for harvest. For more detailed information, including binomials, references, discussion of 
methods and technology involved in harvest and preservation, see secs. $8 a$ and $10 a-10 f$.

(1) Resources Potentially Available for Harvest A11 Year Round

$\underline{\text { Resource }}$

B1ack-tailed deer

White-tailed deer

E1k

Water-oriented mammals (beaver, land otter, etc.)

Other small and medium-sized mammals (rabbits, squirrels, various carnivores)

"Game" birds (ruffed and blue grouse, mountain quail, doves and band-tailed pieons)

Non-anadromous fish (trout and suckers)
Locale or Characteristic Habitat

Wooded areas at a11 elevations; mostly occupies small fixed territories year round, though some populations in Coast Range engage in seasonal elevational migrations .

Dense woods and brush in lower hills and on valley floors; in herds from about November to April-May.

Formerly ranged into open country (e.g. lower elevations in Willamette Valley); in herds during fall-winter.

Marshes and streams; abundant in Tualatin and Yamhill River systems.

Mainly mixed open, brushy, wooded habitat.

Mainly mixed open, etc. habitat (doves and pigeons are summer residents).

Tributaries and main streams in Tualatin and Yamhill River systems.

(2) Resources Seasonally Limited in Availability

\section{Resources}

Camas

\section{Locale \\ or Characteristic Habitat}

Wet prairies (e.g. low prairies near river courses; Wapato Lake prairie was one such area)
Approximate

Season When

Harvested

Late March-April

(early "fresh" camas) through September-October Isee sec. $8 a$, 非 (I) 7 

Spring chinook
salmon
Not in Tualatin and Yamhil1 Rivers; probably not in coastal tributaries; available especially at Willamette Falls (probably not directly harvested by the Tualatin) (see sec. $8 b$ )

Various habitats
Apri1-July

Summer into fall

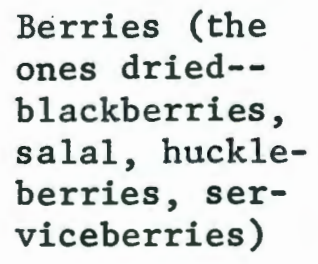

Acorns

Waterfow1
Dry brushy areas (e.g. in hills, foothills of Coast Range)

Ash trees (e.g. in bottomland woods )

Dry prairie

Grassland

Coastal tributaries (e.g. Trask River)

Marshes, shallow lakes (e.g. Wapato Lake)

Oak woods and savannas

On and near marshes and streams
Winter steelhead
Coastal tributaries; perhaps also Tualatin and Yamhill Rivers
July-August

Mids ummer

August-September

August-September

July-December

September-0ctober

About October

Some year round, but main population in winter and during fall and spring migrations

January-Apri1

Note the variety of riverine, lowland, and upland habitats represented above. Tualatin territory (as drawn from informants' statements, treaty documents, and other historical sources) took in a full range of these habitat types. With the exception of the spring and fall salmon 
runs (and possibly steelhead runs), all of the resources listed above must have been directly available within Tualatin territory. One problem in evaluating resource availability is the issue of regional sharing of resources (harvest trips to neighboring territories, access by outsiders to Tualatin territory)-- see sec. 7 .

6b. Calendar and Yearly Round

The most specific information available on the seasonal cycle of any Kalapuyan group occurs in Gatschet's (1877b:80) Tualatin vocabulary MS, in the form of a calendar listing names of twelve lunar months (each month starting with the new moon, the year starting in late August or early September), together with brief descriptions of characteristic activities or seasonal conditions for each month. I paraphrase this below. The calendar is prefaced with the comment that the "old people" had only six months because they did not count the summer months. There is however no indication as to which month the "old people" started their calendar with, nor as to how the presumably more recent twelvemonth calendar might have synchronized the lunar and solar years.

(1) ačiucu tin. First month; beginning with the first new moon in late August-early September. The Indians are still out (i.e., living in the open in their dry-season camps). ma'mptu (wapato) harvesttime approaches around the end of this month.

(2) ača/lankwaik. ma/mptu harvest commences; the Indians move their camps close to the lake (presumably, Wapato Lake), where they stay for one month.

(3) alalngitapi. The Indians prepare their winter houses for the coming winter (and move into them?). 
(4) a a a'mpak (ato'b). - Jya'mpak 'chief' (apparently means 'good' here); -tob 'moon, month.' It's getting colder but the weather is not too bad yet.

(5) $a^{\prime}$ talka (ato'b). Winter dancing is going on. All the Indians are in their winter houses, keeping the fires going all day long.

(6) ači'ulantaj. Said to mean 'out of provision.' Hunters are going out into the woods. A lean time. The 1877a MS (1877a:68) has ači//ulandač (Frachtenberg giving a ̌yu.'lantač), referring to a snowy winter month.

(7) $\underline{a c ̌ a} / u_{y}^{u}(\underline{a t o / b})$. First spring (about March). Some people leave their houses (to camp out). Women begin digging the first shoots of camas, which at that time are only about a finger high. Cf. aca/uyu (Frachtenberg ča'wiyu 'March'), a winter month (1887a:68).

(8) ama'nta kitantal. The camas is growing higher and, for the first time in the new season, is pit-oven roasted and pounded into "a sort of bread." The information that camas was not pit-oven roasted until the season was somewhat advanced is borne out by Eustace Howard (Jacobs 1928-36 非3:137); Eustace stated that early "fresh" camas; gotten in March or early April, was boiled at once for eating, not pit-oven roasted.

(9) ata'ntal. Said to mean 'pounded' (referring to the "pounding" of camas?). About May. The camas begins blossoming. The Indians leave their winter houses to camp out. Salmon are coming up the rivers (which rivers?).

(10) ani'salyu (ato'b). The camas is fully ripe now and the women are gathering and drying it for the following winter; "this is 
done all summer." "Catch all sorts of fish." 'Cf. the 1877a MS (1877a: 68), where nišna/1xit, which also means 'spring,' is given as the name of a month, about May, which follows the month named $\underline{ \pm a^{\prime} b}, \underline{ \pm a^{\prime}}$ bi, the "budding month," about April; apparently, we are being given two rather variant calendars, perhaps representing different informants.

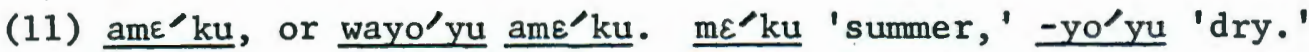
Midst of summer, the weather is getting dry and hot. Cf. $\underline{\text { ame }} \mathbf{k}^{\mathrm{W}}$ (Frachtenberg mh/gwa), a summer month (1877a:68).

(12) aku'piu. End of summer (August), hot weather. Cf. $g \cdot u^{\prime} b$, g.u'bi (Frachtenberg gup), about August (1877a:68).

This calendar, of course, does not present a complete picture of the Tualatin subsistence cycle. However, it puts some of the more important subsistence pursuits (especially, the wapato and camas harvests, also, to a lesser extent, hunting and perhaps fishing activity) in seasonal context, and it indicates the basic division of the Tualatin year into two portions, that spent in temporary camps, and that spent in multifamily houses at permanent winter village locations. The same sort of dual division of the year is indicated in information on other Kalapuyan groups. Jacobs' (1945:39) and Frachtenberg's (1914a:n.p.) Santiam and Mary's River informants both imply such a division of the year, noting that summertime was spent in open camps (shelter, if any, consisting of grass and fir-bough huts or fir-branch windbreaks), while substantial houses were built for winter residence. Jesse Applegate (1930:189) observed that a certain local group (consisting of a prominent man and his relatives; probably Yamhil1), residents of the DallasRickreal Creek neighborhood during the 1840s, had "permanent quarters" 
in "winter houses," but moved about during the drier season: "at this place I Rickreal Creek_/ the Indians built their best houses; and moving from place to place during the dry season, returned to them as winter approached." The same Jesse Applegate was a member of the first White family to settle in the Yoncalla-Drain neighborhood, and also commented that the local Yoncalla "chief," Halo, had a substantial winter house but lived in the open, in a grove of oak trees, during the summer (Applegate 1907:14).

This dual division of the Kalapuyan year obviously paralleled subsistence activity: the part of the year during which temporary camps were occupied coincided with the period of peak harvest activity; on the other hand, harvest activity was at a minimum during the winter season, especially during the coldest part of winter when spirit-power dancing and myth recitation were predominant activities.

In conclusion, I draw upon material from this section and secs. $8 \mathrm{a}$ and $10 \mathrm{a}-10 \mathrm{f}$ to summarize some salient aspects of the Tualatin yearly round.

The Tualatin spent six or more months of the year in temporary open camps. Harvest-season mobility must have been an important advantage of residence in such camps, but the extent and frequency of harvestseason movement is largely undocumented (the Gatschet calendar, and other information, does indicate that camps were moved to Wapato Lake for the annual wapato harvest; also, it seems likely that there were summer-fall camping trips into the Coast Range for large game, berries, and salmon). Vegetable resources were harvested throughout the drier half of the year, from about March (when the first shoots of camas be- 
gan appearing) at least well into October. One important harvest was the camas harvest, which persisted (presumably at intervals) from MarchApril through the summer (when camas was preserved in quantity, often in the form of cakes which probably comprised important articles of trade as well as important contributions to winter sustenance) and into September (when the roots were starchiest). Wapato Lake prairie was apparently one area having an abundance of camas (this is intimated in the proceedings of the Champoeg Treaty I in Mackey 1974:105_T, where it is noted that Wapato Lake and its immediate vicinity had "great quantities" of both wapato and camas). By midsummer, hazelnuts and berries would have been available. Around late summer and into the fall, Tualatins probably embarked on berrypicking and hunting (and, probably, sa1mon/steelhead-fishing) expeditions into the Coast Range (the bit of evidence for Tualatin fishing expeditions to coastal tributaries indicates that while women harvested wapato at Wapato Lake, men went to Trask River to fish; see sec. $8 \mathrm{~b}$ ). Sometime in the very dry late summer-early fall period, the dry grasslands on which tarweeds grew were set afire and the women harvested tarweed seeds.

Availability of small and large mammals was, for the most part, not seasonally restricted, though populations of many mammals are subject to fluctuations. It is specifically mentioned that trapping (i.e., of small mammals, probably for the fur trade as well as for subsistence). was done all year (Gatschet $1877 \mathrm{~b}: 80$ ). Notable (presumably mainly large-game) hunting areas, used in common by the various Tualatin 1ocal groups, included the Tualatin Mountains, the Coast Range as far as Clatskanie and Tillamook territories, and the Lafayette area south to 
the main Yamhill River (the boundary of Yamhill country) (see sec. 7). Among other resources: Waterfowl were probably very abundantly available during the spring and fall migrations (cf. Clyman's $I$ 1960: 117-123_T glowing descriptions of migration-season waterfowl abundance in the Willamette Valley in the 1840s); note that marshlands were formerly more extensive in Tualatin country than at present. Lamprey eels were taken by hand in small creeks and at Willamette Falls where, so Jacobs' Santiam data record, they were picked off the rocks during the spring migration season (apparently, the Chinookans who resided at the Falls and rigidly controlled the salmon fishery there did not mind if outsiders procured lamprey eels). Spring chinook salmon were not directly available within Tualatin territory, but were traded in quantity (especially in dried, pulverized form) from neighboring lower Willamette and middle Columbia Chinookans.

7. REGIONAL INTERRELATIONSHIPS: SHARING OF RESOURCES AND EXCHANGE OF SUBSISTENCE COMMODITIES

A key issue here is that of how aboriginal political territories were defined in the area; more particularly, how such definition related to individual and group rights of access to productive locales. Some of Gibbs' general comments on the Chinookans and general western Washington groups provide a staring point for considering the sketchy record on the Tualatin.

As far as I can gather the views of the Sound tribes, they recognize no individual right to land except actual occupancy. . - Among the Tsinūk and Lower Tsihalis, the right may have been carried somewhat further, but unsettled lands away from their usual haunts are but little regarded. Tribes are; however, somewhat tenacious of territorial right, and we11 under- 
stand their respective limits; but this seems to be merely as regards their title, and they never, it is believed, exclude from them other friendly tribes. It would appear also that these lands are considered to survive to the last remnant of a tribe, after its existence as such has in fact ceased. . . . As regards the fisheries, they are held in common, and no tribe pretends to claim from another, or from individuals seigniorage for the right of taking. . . Nor do they have disputes as to their hunting grounds. Land and sea appear to be open to a11 with whom they are not at war (Gibbs 1877:186187).

This picture seems to generally hold, with some reservations, for the Tualatin and neighboring native groups. Gibbs' use of the term "tribe" here is ambiguous. I elsewhere (sec. 3) discuss the problem of Kalapuyan group identity, observing that, although the evidence is not conclusive, it does suggest that what I call dialectal-ethnic entities (Tualatin, Yamhill, Santiam, etc.) did have some degree of socio-political identity. The picture suggested for the Tualatin by Gatschet's notes is that of a cluster of socially and politically closely interrelated winter-village groups, each probably holding its own rights of access to certain resources in certain locales, but a11 sharing access to productive locales within a larger common territory. Gatschet's notes furthermore suggest that the limits of Tualatin territory were definitely drawn, at least as regards their "title" (to use Gibbs' choice of words). One of Gatschet's texts (1877a:151) states (quoting Jacobs' translation [Jacobs 1945:187-1887):

Perhaps if they I the Tualatin_/ crossed to the Yamhill country a man who hunted (there) might get killed. (Beyond) half the mountain at $\mathrm{pa} /$ naxDin I the northermost Tualatin winter-village group_/, if they (the people of that village) should cross over (that mountain) to Clatskanie country, perhaps a Ba/naxDin (villager) would be killed. If a Clatskanie should cross over, possibly the Clatskanie would be killed (by a Tualatin).

A note to this text, apparently from Dave (the text being given 
by Peter) denies the statement that a Tualatin crossing into Yamhill country might be killed. "They never would have been killed by the Yamhills, they could go themselves over the 1ine. (Yamhill River was 1ine.) The coyote never left orders of this kind $I_{i}$.e., Tualatins and Yamhills killing each other for 'crossing the 1ine'_f' (1877a:152). However, the note adds that the case was different as regards the Clatskanie, as the latter were of "different type." In another note to the same text, Dave comments further on the relationship between the Tualatin and Clatskanie, indicating that "if they $\perp$ the Tualatin_ $\bar{I}$ were called $I$ by the Clatskanie_T then they have a right to cross the line" (1877a:324). Taking Dave's clarifications here at face value, we have a clear statement that the line between Tualatin territory and that of the culturally closely related Yamhill was definitely drawn, but only as regards "title," while the territorial boundary with the more alien clatskanie functioned rather differently (note though that the attitude towards the Clatskanie thus shown does not necessarily evidence actual enmity between the two groups, it being stated [1877a:280_T that the Tualatin "never fought them I the clatskanies_T").

I am unable to interpret exactly what the Gatschet MS says about the western boundary of Tualatin territory. The text cited above also reads (quoting Jacobs' translation again): "The Tualatins hunted halfway in the mountains (between) pa.'?fan (the Tillamook country ... and ) the Tualatin mountains I apparently, the eastern section of the Coast Range rather than the hills west of Portland and Sauvie's Island now known as the Tualatin Mountains_T". I am not sure what "halfway" (ku'pfan, Jacobs' correction for Gatschet's ko/p'fon 'one half I in 
quantity_ $T$ ', 'halfway', 'middle') means in this connection-- 1iterally (or more or less) halfway between the cosst and the eastern part of the Coast Range?, or (as Whites draw boundaries, and, indeed, as the 1851 and 1855 treaty documents draw the Tualatin western boundary) to the summit or divide between coastward and inland flowing water? Perhaps, on the other hand, the rugged, wild character of Coast Range country precluded any necessity for exactly defining political territories, even as regards "title." Regardless of the exact relationship here between territory as defined by subsistence activities and as defined political$1 y$, there is good reason to suppose that the various neighboring groups of the area shared access to productive locales (hunting, berry-gathering, fishing) within the general Coast Range area.' Recall Gibbs'statement that "tribes" ". . . never, it is believed, exclude from I their territories_T other friendly tribes;" this statement seems borne out for the Tualatin by Gatschet's notes, considered below.

An interesting consideration at this point is suggested by Nelson Strong's (1906) account of his boyhood on the lower Columbia. Strong emphasizes the vastness of the wilderness which lay beyond the (aborigina11y) we11-traveled and settled river courses and prairies, commenting that what I call the "productive locales" within this vastness (e.g., prime hunting country; one such area, favored, says Strong, for its elk and bear hunting, extended southward from Cathlamet Head towards the Nehalem River and westward towards the coast), were well known to the Indians, but that other sections were regarded with "superstitious terror" and avoided. Strong uses the Jargon term "mesatchie illihee," "bad country," to refer to such areas; he locates one such area near 
Brookfield, Washington (Strong $1906: 26,36-38$ ). I have no direct indications as to what areas the Tualatin might have regarded as "mesatchie illihee," although, from the description I cf. sec. 10h, 非(2) $\bar{T}$, Devil's Lake near South Saddle Mountain could well have been such an area. Jesse Applegate's reminiscences of early farm life near Dallas in the mid-1840s point to one area of mesatchie illihee, somewhat farther south. Applegate states that no Indian would consent to guide his father into the section of the Coast Range near the family farm. Jesse's father finally took matters into his own hands, taking young Jesse and making the trip to the coast and back himself.

We returned home in less than a week. That we returned unharmed seemed to astonish the natives. They asked many questions as to where we went and what we saw. Some of the Indians assured us, as their reason for not going with us, that there was a very dangerous goblin in the Coast mountains, whose awful name was Chuchonnyhoof (Applegate 1930:187).

The Gatschet notes are sketchy but suggestive regarding sharing of productive locales across political boundaries. That the Tualatin would not have been excluded from territory under Tillamook "title" is suggested by the note that, although the Tualatin did not go to the ocean to fish, they did go there to trade and intermarry with the Tillamook (indeed, one Tualatin man, a village chief, is mentioned as having been half Tillamook) (1877a:93, 168, 344). It is also states that the Tualatin never went to fish in the Columbia River (1877a:94); however, it is indicated that Tualatins sometimes caught seals there (1877a:344). That outsiders were not excluded from Tualatin country is indicated by the statement that the Klickitat came across the Columbia "because there is no game in their country" and sometimes settled in Tualatin country: "after the fish-time was over, they could get 
camas here \& hunt" (1877a:324). Hunting expeditions by some southwestern Washington group (1ikely, Klickitats) into the Willamette Valley are documented well back into the historical period by an entry in Alexander Henry's journal (in Coues 1897:879), dated April 9, 1814: "The Mt. St. Helena Isic_/ Indians were assembled on the Columbia, on their way to the Willamette to hunt deer this summer, as they usually do."

The Gatschet notes suggest one notable variance from the general pattern described by Gibbs: contrary to Gibbs' statement that fisheries were "held in common," open equally to different "tribes" and individuals, the Willamette Falls Chinookans seem to have controlled foreign (at least, non-Chinookan foreign) access to the salmon fishery there. A. text, probably from Peter, states (my own translation): The $\mathrm{f} \varepsilon^{\prime} \breve{I}$ I Lower Willamette-Vancouver Chinookans_ $/$ did not want them I the Tualatins_T to use dip nets to get spring chinook salmon $\Gamma$ amhu'ya / at Willamette Falls I the MS says "seine net" here, but the same word is elsewhere translated as 'dip net,' e.g. "used at Oregon City;" my impression is that the falls fishery was primarily a dip-net fishery_ $T$, they $\perp$ also $T$ did not want them to spear spring chinook salmon, the $f_{\varepsilon} Y \bar{d} \overline{i d}$ not want the Tualatin to go to Willamette Falls (1877a:153).

It seems likely that the last part of this quote is either overstated or incompletely stated-- the importance of Willamette Falls as a regional center of aboriginal commerce seems fairly well documented. There is also information from a Santiam informant (Jacobs 1945:24) stating that "all the people" (?) went to Willamette Falls to get lamprey eels, suggesting that the $\underline{f} \mathcal{\prime}=$ did not mind if outsiders got their own lamprey eels at the falls. While I was unable to find other references commenting directly upon control of access to the Willamette Falls fishery, informants' statements and historical sources do agree in suggesting that foreign groups got salmon at the falls through 
trade. Some references in this regard have previously been cited: cf. the discussion of regional specialization as reflected in the exchanges of subsistence commodities at the falls (sec. 5) and the 1814 mention of Yamhills trading camas for dried salmon at the falls (sec. 2a). Another historical reference is provided by the early mountain man and settler Robert Newell, in his 1849 report to Governor Lane on Indians west of the Cascades.

They I "the Willamettes" or Willamette Falls Chinookans_/ subsist principally on fish which they take in large numbers in a proper season of the year. Many natives go there to trade fish and get a winter supply of provisions. Many parts of bands depend upon the fishing more or less for fish which they trade principally from the Willamettes (Newell 1959:148).

Reference to Tualatin participation in this trade occurs in another one of Peter's texts (1877a:166; translation slightly modified from Jacobs \1945:189_/).

They I the Tualatin_ $T$ brought it I salmon_ $T$ from far away at Oregon City Falls, (or) at wa'qanasi.s (a place on the Columbia below Vancouver), 'dried pounded salmnn' I ake'zoz/ that had been ground, its name was ake'łot.

Mrs. Howard (Jacobs ca. 1929-30:n.p.) mentioned that pulverized

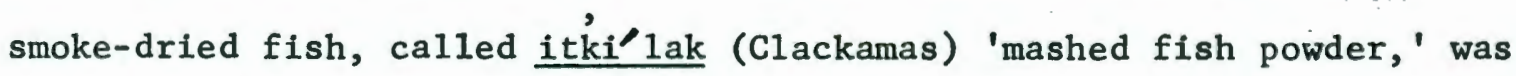
sold to the foreign groups that came to the falls. It seems likely that this was the same dried, pulverized product that Lewis and Clark observed being prepared in large quantities, stored in baskets, and used extensively for trade, at The Dalles in 1804 (Spier and Sapir 1930:178-179; Spier and Sapir were also told of the same product, "dried pulverized salmon," used for trade and winter food, by their Wishram informants).

This discussion brings up the general issue of the contribution 
to Tualatin subsistence provided by regional exchanges of subsistence commodities. The data are inadequate here, but the Gatschet MSS and Jacobs' Clackamas notes do permit some general comments upon 1ocal aboriginal trade.

Certain subsistence commodities which Tualatin country produced in abundance (e.g. wapato, deer meat, and camas), and slaves, gotten by trade or by raid (there is no definite indication as to which of these avenues was most favored by the Tualatin), were among the Tualatin contributions to the trade at Willamette Falls (Gatschet 1877a:94, Jacobs ca. 1929-30:n.p.). Other commodities noted to have been involved in regional trade were: dentalium shells (strung together and standardized in value according to number of shells per length), bone and shell beads (some strung together and standardized according to length of string), ornamental jewelry (breast pieces, nose and ear ornaments, etc.; also, beads, feathers, red-headed woodpecker scalps, and other articles used in ceremonial regalia), tobacco, animal skins (e.g. otter skins, used in ceremonial and wealthy persons' attire; buckskins, etc), and historical introductions such as trade beads, blankets, Hudson's Bay Company jackets, guns and gunpowder, horses (Gatschet 1877a:111, 129; Jacobs ca. 1929-30:n.p.). According to Mrs. Howard, trading transactions did not consist of buying and selling, but rather of formalized gift-giving, at least to outward appearance. To paraphrase Jacobs' notes: When a group of foreigners arrived at a village on a trading expedition they did not speak of the prices of their products or of exchanging them. They presented their goods to the village headman or host. The latter took some of the goods and shared the remainder with his fellow 
villagers, who at once inquired when the visitors were to depart.: Short1y before the indicated departure, villagers turned up at the hosts' house, presenting the host with goods which he forthwith gave to the visitors. Upon arriving in their own village, the visitors shared the received goods with fellow villagers.

\section{SOME MAJOR SUBSISTENCE RESOURCES}

8a. Activities and Technology Related to Harvest and Preparation of Some Major Resources

For additional information (especially, binomials and more complete data on native terms) concerning these resources and others not considered here, see secs. 10a-10f.

(1) Camas (ma'ntip 'raw camas,' ma'mišs 'cooked camas'). The Gatschet MSS (1877a:169, 195; 1877b:40, 80) have the following regarding the harvest of camas.

Camas was first harvested as soon as its shoots were about one finger high (sometime in March); however, it was not pit-oven roasted until farther along in the season. (Jacobs' Santiam notes $\perp_{1928-36}$ 非83:135, 137_T, from Eustace Howard, state that early "fresh" camas, Di'p, was gotten in March or early April, often in gopher burrows where quantities of bulbs could sometimes be found; it was boiled at once and eaten, not pit-oven roasted.) Camas was considered fully ripe in June, when it was harvested in quantity, pit-oven roasted, dried for winter, and "pounded" into "a sort of bread" (pressed into cakes?). (Jacobs again has similar information from Howard, who indicates that the Santiam harvested the "large camas," mi.'s, in greatest quantity during June.) The camas harvest went on throughout the summer. There is some 
evidence that Kalapuyans harvested camas wellinto the fall. David Douglas (1959:215), while some distance south of Yamhil1 River, on October 1, 1826, passed some Indians digging camas (which he identifies with a proper if outdated binomial), the bulbs of which were much larger than he had ever seen except on one other occasion. Incidentally, the seeming reference to fall harvest of camas in Jacobs' (1945:190) reworked version of Gatschet's Tualatin texts is in serious error; the word translated as 'camas,' ma'mpDu, is rather the word for 'wapato' I see 非(2) below_T.

Harvesting of vegetable resources was the work of women. To harvest camas, women used a digging stick ( $m \varepsilon^{\prime} k w i$, Frachtenberg has me. $\mathrm{kwi}^{\circ}$ ) made from a piece of serviceberry wood (a very hard wood), bent in the

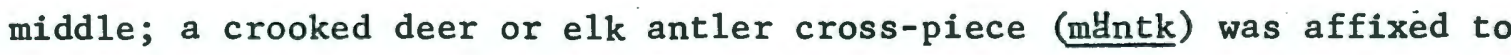
the upper end of the stick and held against the belly during the digging operation.

Gatschet has few details on cooking and preservation of camas. Camas was pit-oven roasted for about two days; it might be fire-dried for preservation. The "pounding" of camas into "a sort of bread," noted above, is 1ikely a reference to the pressed-camas cakes elsewhere referred to as a Kalapuyan staple and trade article (cf. Alexander Henry's observations, quoted pp. 32-33; Eustace indicated that cooked camas was pressed into "camas cakes," Du'pkwaik, about two inches thick and three to six inches in diameter, resembling hotcakes). Jacobs' Santiam information is more complete on such matters. Eustace Howard (Jacobs 1928-36 非81:60, 非83:135, 137) indicated that pit ovens were three to four feet wide and one to one-and-a-half feet deep (John Hud- 
son IJacobs ca. 1928:6_T, on the other hand, indicating that ovens were two to two-and-a-half feet deep). Numbers of these pits (oval-shaped, according to Hudson) might be dug on a particular occasion. Glowinghot rocks were put into the bottom of the pit. Leaves (mostly maple; sometimes skunk cabbage but not so much due to its relative scarcity; often ash, but least preferably due to its tendency to make the camas dry) were put over the rocks; then the camas was put in, then more leaves, then dirt was put on top to seal the oven. The camas was tested after three days; it was left in the pit for about four or five days total. John Hudson (Jacobs ca. 1928:6, 1945:18-19) described another method, differing from Eustace's in having a fire on top of the oven which was maintained for some time. In this method, the camas was left in the oven for from two days and two nights to three days and three nights. When cooked, camas to be preserved was carefully dried in the sun; if dried too much it would be too dry, if too little it would become mouldy in storage (Jacobs 1928-36 非83:137). It was stored in sacks (probably hide or basketry in aboriginal times).

An excellent description of Kalapuyan camas harvesting and preparation occurs in the mountain man James Clyman's journal. Camped near Luckiamute River on May 28, 1845, C1yman commented:

It is remarkable to see the great Quantity of esculent roots that grows in all parts of this vally Ten or Twelve acres of cammace in one marsh is Quite common and in many instances it will yield 20 Bushel to the acre the Calapooyas live exclusive$1 y$ on roots but whare hogs are introduced they soon destroy the cammerce fields these extensive fields are allways on wet land and in many places no other vegitable is found to intermix with it I Spelling as in the original_/ (C1yman 1960:153).

From the same camp, a few days later (May 31), Clyman observed:

The day proved to be verry warm in the low vally The Indians 
our neighbors ware out early diging roots this operation is performed by sinking a strong hard stick in the ground near the roots to be dug then taking pry on the outer extremity of the stick a portion of earth containing frorm 2 to six roots is taken up the roots being the size of a small onion and much resembling the onion in appearance They are then washed and clensed a hole of suitable size is dug in the earth filled with wood and stones after the earth and stones become well heated the fire is taken off and a Layer of green grass laid over the hot stones the roots piled on the grass and a Layer of grass laid over the roots then a thin layer of earth over the whole and a fire outside of all which is kept up some 24 hours when it is allowed to cool down and the roots are ready for use or for drying and putting away for future use when dry they keep for months or years I Spelling as in the original_/ (C1yman 1960:153).

(2) Wapato (ma'mptu). I have previously noted the serious error in Jacobs' (1945:190) reworked version of Gatschet's Tualatin texts. In the passage beginning with the sentence "I myself know that in autumn the camas were gathered," the word ma'mptu (ma'mpDu in Jacobs' phonetic reinterpretation), 'wapato,' is mistranslated as 'camss.' The passage referred to describes the harvesting of wapato at Wapato Lake, where there was a major wapato harvest place located on the northern end of the lake (Gatschet 1877a:93). With the mistranslation corrected, and with some other comments based on my own reading of the original Gatschet text, Jacobs' rendering of this passage is as follows:

I myself know that in autumn I Jacobs has a question, "(?)," here, perhaps because he questions camas being harvested in the autumn-- the translation however is correct / the I wapato_/ were gathered. The women dug them, they made 1 holes_ 1 Jacobs has "a ground oven hole," but I disagree-- Gatschet notes that these holes in which the wapato tubers were put were four to five feet deep, about twice as deep as the Santiam camas ovens described above; his translation furthermore seems to me to imply that the purpose of the holes was to "keep," i.e., preserve and store, the roots; it appears that the text describes a preservation-storage technique rather than a cooking technique_ $T$, and they put them in it, so that they could preserve them for wintertime to be eaten_in wintertime. They got them at the lake, the women got I wapato_/ underneath the 
ground, they picked them up, they got them. When the lake was 'overflooded we named it 'step in the water,' the women stepped in the water.

Beyond this, few details are given on wapato harvesting and preparation. The word translated by Jacobs as 'stepped' ("the women stepped in the water") is elsewhere given by Gatschet as referring to "stamping" in the water to get "potatoes" (wapato tubers) out, an apparent reference to the use of bare feet to dislodge wapato tubers from the soft underwater muck of a pond or marsh (as is described by Lewis and Clark for Chinookans of the Sauvie's Island vicinity I Thwaites 1905 Vo1. 4:217-218_T). The term azthki (Frachtenberg has a sly'g) is given elsewhere as "stick to collect potatoes I wapatos_ in water" (Gatschet 1877a:28). The following note also occurs (1877a:73): "ma'mptu; 2" 1ong, 1" thick, tail to it bent, hard when boiled, sweet, white inside... ."

Dickson (1946), who has much interesting information (some of it from Indian informants, including John Hudson), the source of which she unfortunately does not always identify, has the following on Tualatin preparation of wapato (unfortunately, one of her unreferenced items):

The Indians near Gaston, Oregon would build a fire on top of the ground as you build a bonfire today. Then, they would spread the ashes apart, put the Wapato in these ashes and cover them up with more ashes. Over the top of the fire, the natives spread a layer of dirt and cooked the tubers for 15 to 20 minutes. When done, the Wappato I sic_/ was mealy like a potato (Dickson 1946:38).

(3) Tarweed Seeds (ato ${ }^{\prime}$ ). In other Kalapuyan dialects (Santiam, Mary's River, Yoncalla), there is some ambiguity regarding the denotations of the terms corresponding to Tualatin -tok on the one hand, 
and -̌̌a'wal, 'sunflower seeds,' on the other I see sec. 10a-1, 非(22), (23)_T. In different instances, each term appears both as 'sunflower' and 'tarweed;'-ša'wal furthermore appears in Mary's River (and in Clackamas Chinookan) as both 'sunflower' and 'tarweed.' These facts surely reflect close similarities between these plants, e.g. in type of food provided (seeds), preparation: methods (parching and grinding), and (likely) harvest methods (use of fire?).

As previously noted, each Tualatin winter-village group had its own tarweed-producing area within which individuals (at 1east, we would presume, wealthy individuals) owned their own sub-plots. These areas were set afire about August (Gatschet 1877a:92). Women then went out with rawhide buckets (ako/u; Jacobs, dubiously, reads $\underline{a G u \cdot / n \text { ) }}$ and paddles (abu'b, Frachtenberg has pơ?p); the seeds were beaten from the plants into the buckets $(1877 a: 169,196)$. It is stated that each "lot" (individually owned plot) might produce 10-20 bushels of seeds (1877a: 92). A long conical basket, with a hoop, wetted first, was involved in the harvest (presumably, to receive the seeds from the bucket); the implied function and Gatschet's 1ittle sketch of this instrument suggests that it is identical to the type of basket designated 'ca.'Bu? in Jacobs' Santiam notes (1928-36 非76:120). Jacobs provides a sketch of a conica1, wide-mouthed basket, as well as the information that this was a large basket carried by women on their backs, used for carrying wood and bark and for harvesting tarweed seeds-- "tarweeds are hit and the seeds fall into a platter or cupped light tight pan, the seed contents of which are then poured into the 'a.Bu? "

Tarweed seeds were preserved by. parching, which was accomplished 
by mixing them with hot coals on a board of ash-timber (amhe'/ip 'parcher'). After parching, the seeds were ground in a stone mortar (ana') by means of a stone pestle (a/nkwi). The prepared seeds might be further mixed with camas $(1877 a: 92,169,196)$. Jacobs' Santiam texts (1945: 20) state that pulverized tarweed seeds, mashed cooked camas, and haze1nuts might be mixed together.

One early settler's description of Kalapuyan (probably, Yamhill) tarweed-seed harvest has been quoted previously (Applegate's I 1930: 178-179_T, quoted p.23). An early settler of the Cow Creek Valley near Riddle (some distance south of the Willamette Valley, in the Umpqua River drainage), gives a fuller description of tarweed harvest and preparation; this applies to the Cow Creek area rather than to the Willamette Valley, but it obviously parallels the less specific information for the Willamette Valley.

During the summer months the squaws would gather various kinds of seeds of which the tar weed seed was the most prized. The tar weed was a plant about thirty inches high and was very abundant on the bench lands of the valley, and was a great nuisance at maturity. It would be covered with globules of clear tarry substance that would coat the head and legs of stock as if they had been coated with tar. When the seeds were ripe the country was burned off. This left the plant standing with the tar burned off and the seeds left in the pods. Immediately after the fire there would be an army of squaws armed with an implement made of twigs shaped like a tennis racket with their basket swung in front they would beat the seeds from the pods into the basket. This seed gathering would only last a few days and every squaw in the tribe seemed to be doing her level best to make all the noise she could, beating her racket against the top of her basket. All seeds were ground into meal with a mortar and pestle. The mortar was formed by forming a round hollow in the face of flat boulders, over which was placed a basket with a hole in the bottom to fit the depression in the rock, forming a kind of hopper to hold the seeds, then with a stone fashioned about two inches in diameter at lower end and tapering to the other end to a size easily grasped with the hand the operator would sit upon the ground with the mortar between her knees and would pound the seeds, using the pestle 
which was usually about ten inches long, and weighing five or six pounds, . . (Riddle 1920:45-46).

(4) Berries (aka'yan). Some kinds of berries, such as strawberries and blackcaps, were eaten only or mainly fresh. A few kinds of berries were preseved by drying and kept as winter provisions. The more important among the latter were blackberries, salal berries, huckleberries, and serviceberries.

Louis Kenoyer, in one of the few texts from him which has any detailed description of subsistence-related activity, recalled, from his boyhood, how berries were dried at a summer berry-gathering and hunting camp in the Coast Range west of Grand Ronde. Louis and a hunter named Yamhill Joe gathered firbark and firewood. The berries, picked by Louis' mother and other women, were put on the pieces of bark, with the firewood being placed nearby. The firewood was lit and the berries were dried for about half the night, at which point Louis and Joe retired and let the fires go out. The fires were relit in the morning and kept going all day, the berries being watched carefully. The women came back from the berry picking areas in the evening, removed the dried berries, and placed fresh berries on the slabs. Again, the fresh berries were dried for half the night (Jacobs ca.1936:paragraph 非3).

(5) Acorns (ako'hon). Acorns apparently were not a major contribution to Kalapuyan subsistence, at least in later times. Eustace Howard (Jacobs 1928-36 \#83:139) indicated that acorns were picked up in October, but were 1ittle used. The Gatschet notes (1877a:32) indicate that the Tualatin gave up using acorns "over 20 years ago," i.e., at about the time they came to the reservation.

Gatschet (1877a:32) notes two methods of leaching acorns. In 
one, "acorn mush" (pulverized acorn flesh?) was kept immersed in water, in a basket, for I six? T months (compare the method described by John Hudson I Jacobs 1945:20_/, in which acorns are first extracted from their shells and dried, then immersed in water in a "small soft-1ong basket" for only a day and a night). In the other method, the acorns were baked on (hot) rocks (to crack the shells so that the flesh could be extracted, as described by Hudson?), (then) buried in the ground in (with?) "blue clay" (a'mptank); in the winter, the acorns were dug up and the clay washed off (an early settler I Ramsdel1, 1907:12_ $/$ refers to such a method-- Ramsdell notes that the Indians of the Willamette Valley prepared acorns by first burying them in wet clay "indefinitely," then "steaming" them).

For eating, "acorn mush" (ašma/1క̌mal 'mush') might be mixed with deer's blood. A note from Dave at this point disagrees somewhat with the latter information, which was apparently given by Peter; Dave indicated that the blood was eaten separately, as a soup, and that acorn mush and deer meat were pounded together and eaten as a sort of hash $(1877 \mathrm{a}: 32,114)$

(6) Fisheries Resources. Problems in evaluating the extent of the salmon resource which would have been directly available to Kalapuyans are discussed in sec. $8 \mathrm{~b}$. The Gatschet MSS have references to fishing by net (e.g., for salmon with dip nets at Willamette Falls), spear, stationary basketwork traps (for trout), and line (trout). Additionally, it is mentioned that suckers and lamprey eels were caught bare-handed. Use of nets is only alluded to (words being given for 'net' of any kind and 'dip net'), and it is furthermore specifically 
indicated that Tualatins did not fish for salmon at the dip-net fishery at Willamette Falls. The other mentioned methods (excepting the barehanded method) are briefly considered below.

(i) Spearing. The Gatschet notes contain expressions for 'fishspear,' 'I fish with a spear,' 'I fish with a light and spear.' The latter apparently refers to fishing at night, with the aid of torches (perhaps pitch-brands, indicated by John Hudson I Jacobs 1945:24-25_T to have been used in night-time fishing for lamprey eels). Spear fishing at night by torchlight is also indicated by Frachtenberg (1914a: n.p.) for the Mary's River; the Frachtenberg notes further indicate that fish spears were eight to ten feet long, with points made of hardwood or bone. The Gatschet notes give no indication of specific species taken by spear. However, references to the taking of salmon by spear occur in the Santiam and Mary's River material, in myths given by John Hudson and William Hartless (Jacobs 1945:92-95, 224). In the Santiam myth, it is indicated that a harpoon (i.e., a spear with a detachable head and connecting thong) was used.

(ii) Traps. Basketwork traps (wદ' left overnight, were used to get trout $(1877 a: 73,153)$. I found no descriptions of this device.

(iii) Line. One of the Gatschet texts (1877a:153, in Jacobs 1945: 188) briefly mentions the catching of trout by line, using grasshoppers as bait. It is elsewhere (1877a:280) mentioned that "rainworms" were also used as bait. Additionally (1877a:73), the word tu/nY, tu'nYi (1iterally, 'bone') is given as "fish hook" (gorge?). John Hudson (Jacobs 1945:18). indicated that trout were caught with tufts of human 
hair (as lures?) on the ends of inner willow-bark lines.

(7) Sma11 and Medium-Sized Game. One of Gatschet's texts (1877a: 167-168, in Jacobs $1945: 189-190$ ) specifically notes that the following birds and sma11 and medium-sized mammals were eaten by the Tualatin: beaver, seal (sometimes gotten by the Tualatin in the Columbia River), mountain 1ion, grey-digger squirrel, rabbit, bobcat, raccoon, swan, wild geese (three different types indicated), "pheasant" (ruffed grouse), grouse (blue grouse), quail, (band-tailed) pigeon, duck (any kind), smallest duck (sp.?). The list is not exhaustive, but notes to the effect that certain animals were hunted do not necessarily mean that they were eaten (e.g., coyotes and grizzlies were killed but not eaten). Dogs were not eaten (Jacobs ca. 1936b:12; Tualatin and Santiam).

Kalapuyan cooking methods recorded in connection with small and medium-sized game include roasting (on spits, in ashes, or over coals or an open fire) and boiling by means of hot stones put in water in water-tight containers.

(8) Large Game. Large mammals which were hunted and eaten by the Tualatin included black bear, elk, black-tailed deer, and white-tailed deer. Grizzlies were killed but not eaten.

The only information in the Gatschet notes on the eating of black bear indicates that this animal was cooked (the notes say "steamed" but the method is not described) on top of hot rocks in a sort of pit oven, after which it was eaten up by those assembled; the rest of the meat might then be taken home to women and children (1877a:167).

There have been some significant changes in the relative abundance and distributional patterns of large game species since the time 
of first White contact and initial settlement. The native subspecies of white-tailed deer (Odocoileus virginianus leucurus), formerly probably the most abundantly represented deer in the Willamette Valley (see Bailey 1936:90-91), is now restricted, in our area, to a small remnant population on the lower Columbia River (Ingles 1965:423). The observations of David Douglas, together with those of early settlers, indicate that this subspecies was found, year-round, in the low hills and on the valley floors of the Willamette Valley, especially in dense thickets and brush (e.g. on river bottoms). Additionally, it is noted that white-tails ran in herds for part of the year, from about November to April or May (Bailey 1936:91). Elk population has not suffered as much as has that of the white-tailed deer, but its distributional pattern has been altered-- formerly, elk were open-country as well as forest animals in this area, while now they are found mainly in remote mountainous areas. Being gregarious, elk likely formerly gathered in herds in the Willamette Valley, especially during the fall and winter (cf. Bailey 1936:82-83). The native subspecies of black-tailed deer (Odocoileus hemionus columbianus) has apparently been affected less by the impact of White settlement than have the other major game animals. It is still abundant in and around dense woods in the Willamette Valley; it generally occupies fixed, relatively small territories year-round, though those black-tails resident in the Coast Range engage in seasonal migrations from higher to lower elevations, and vice versa (cf. Bailey $1936: 87-88$ )

There is very little specific information in the Gatschet MSS concerning hunting methods and hunting-related technology. Thus, I 
depend here more upon Jacobs' (ca. 1936b:51-53, 1945:30-31) Tualatin and Santiam information, and Frachtenberg's (1914a:n.p.) Mary's River information. According to Jacobs' and Franchtenberg's notes, bows were made of yew or oak. John Huds on indicated that bows were made by splitting the selected piece of wood, scraping it with mussel shells and sharp rocks, and finally heating it and rubbing warmed grease into it. Gatschet has an entry in the Powel1 vocabulary schedule for "sinew on back of bow" (1877b:36); Frachtenberg's notes, as well as Jacobs' (ca. 1936b:51) Santiam-Tualatin culture element 1ist, agree here in indicating that bows were strengthened with sinew backing. The Gatschet notes further suggest that the native bow could pack quite a wallop: "arrows often went pretty near through an elk" (1877a:236). The Santiam section of Jacobs' element list indicates that bows were three to four feet long; the Tualatin section (surely from Louis Kenoyer) indicates six feet (which seems rather tall), and additionally indicates that bows were held vertically rather than horizontally. According to Frachtenberg, arrows were made of "arrowwood" (probably, oceanspray, Holodiscus discolor I see 10a-3, 非(64)_T); an arrowhead (made of flint, ana'tu, according to Gatschet [1877b:36_T), lashed on with pitch-glued sinew, was used for larger game, a hardwood point for smaller game; feathers, three to a shaft, were lashed on with pitch-glued sinew. Poison (rattlesnake; the Jacobs' element 1 ist also suggests yellowjacket) was put on tips of arrows only for war, not for hunting.

Some aboriginal hunting methods to which there is reference from the general Kalapuyan area include: (i) use of deer's head disguise or decoy to permit close enough approach to deer for a good shot, (ii) 
noose snares, pitfalls, etc., (iii) communal drives. I consider these below in some detail. The stalking of large game by solitary hunters or small groups of hunters, though surely aboriginal, was especially resorted to after the introduction of fire arms.

(i) Disguise. In this method, the hunter wore a deer's head ("with horns complete" according to one source) over his head, and, approaching a group of deer from down wind, imitated a deer's motions or sounds. This method is first mentioned by Henry (in Coues 1897:817) in 1814, in reference to the "natives" in the vicinity of the Northwest Company's trading establishment somewhere in the French Prairie area. The early French-Clatsop settler Louis Labonte (Lyman 1900a:172), recalling his boyhood on French Prairie in the 1830s, also mentions this method, which he says was one of the pastime of the youths at the settlement (guns rather than bows and arrows being used, however). Labonte adds that this method was particularly used during the breeding season of the deer, since during this time bucks were pugnacious and readily attracted. It seems likely that this method would have been well suited to the white-tailed deer, which during breeding season formed herds in the lowlands. This is confirmed by David Douglas, who describes a slightly variant form of this method, noting that it was used by the "native tribes" of the general area to take the white-tail.

The voice of the male I white-tailed deer_T calling the female is like the sound produced by blowing in the muzzle of a gun or in a hollow cane. . . This is well imitated by the native tribes, with a stem of Heracleum lanatum $\Gamma$ cow parsnip_T, cut at a joint, leaving six inches of a tube: with this, aided by a head and horns of a full grown buck, which the hunter carries with him as a decoy, and which he moves backwards and forwards among the long grass, alternately feigning the voice with the tube, the unsuspecting animal is attracted within a 
few yards in the hope of finding its partner, when instantly springing up, the hunter plants an arrow in his object. (Douglas quoted in Cahalane 1967:280)

Another mention of this method comes from Riddle (1920:44), in reference to the Cow Creek Valley area of the Umpqua drainage.

(ii) Snares, pitfalls, etc. Most frequently mentioned under this category is the use of a rope noose for snaring deer. David Douglas (1904-05 Pt. 5:85), in reference to the Umpqua River area, observed that such nooses were used especially to take the black-tailed deer. Frachtenberg's Mary's River notes (1914a:n.p.) describe a method for providing such a noose snare with a spring mechanism. The spring action was provided by a bent sapling secured by a rope (John Hudson I Jacobs 1945:31-32 T seems to be referring to the same mechanism, though the description is less clear). A rope noose (Hudson says it was made of inner willow bark; farther south, Douglas I 1904-05 Pt. 5:85_ that the fibers of Iris tenax were used) was suspended in some strategic location, the long end of the rope being secured to the top of the bent sapling. When the deer's head entered the noose, the rope holding the sapling pulled free and the deer was securely caught by the neck. Riddle's (1920:45) description of the use of deer snares in the Cow Creek Valley area suggests that such snares might be used in conjunction with communal drives, deer being driven to the strategically placed snares.

Hudson (Jacobs 1945:32) described elk pit-falls, deep pits dug on elk trails, camouflaged by sticks and leaves. The elk were driven (another allusion to communal hunting) towards the pits and clubbed to death when trapped. A similar method (Frachtenberg 1914a:n.p.) con- 
sisted of strategically placing a sharpened stake to pierce the body of a jumping animal.

(iii) Communal. This method has already been alluded to above. In the Gatschet notes, there are two rather tenuous possible references to communal hunting. An expression nitu'm.ia.t is given as 'they surround (a field),' e.g. to "head a deer" (1877a:178). Additionally, Dave's etymology of the name ča-pu'ngatpi I see sec. 12a, 非(12)_T, in which the name is explained as referring to the setting of fires to burn the country or to "drive deer out," is possibly a reference to the use of fire in communal hunting. The closest thing I could find to a Kalapuyan informants' explicit reference to communal hunting is in one of Frachtenberg's Mary's River myths (in Jacobs 1945:228-229), in which the dead people engage in a communal hunt, encircling an area to drive deer and elk (that is, snails-- dead people's deer and elk) along to where Coyote had been instructed to stand by and kill the game. An ear1y settler (Minto 1900:307) does give us a definite reference to communal hunting, for the Santiam; Joseph Hudson (a prominent Santiam chief, signer of the Champoeg and Dayton Treaties), is indicated to have described for Minto a traditional hunting method in which deer were encircled and driven to a center where they were shot with bows and arrows.

I was able to find some specific information on preservation of large game; this is presented below.

The Gatschet notes mention that elk meat was fire-dried on drying scaffolds (1877a:167). Deer meat was doubtless treated the same way, though there is no note to that effect. Louis Kenoyer, in his remin- 
iscences of the same berry-gathering and hunting expedition mentioned previously, described how the hunter named Yamhill Joe dried meat for preservation. A stick scaffold was built, consisting of a framework measuring five to six feet high, three to four feet wide, and six to eight feet long. Cross-sticks were placed across the long horizontal sticks of the framework to form a platform. The women cut the deer meat into small strips, which were placed on the platform. Small fires to dry the meat were built under the scaffold and maintained, without interruption, for two days.

For cooking, meat was generally roasted or stone boiled. David Douglas (1959:219), visiting a "Calapooia lodge" in 1826, observed a woman take a piece of deer rump and pound it with stones, put it into a basket-work kettle in water, throw red-hot stones into the kettle and cover it with a mat until the meat was cooked.

8b. The Salmon Resource-- A Problem Area in the Record on Kalapuyan Subsistence

Disregarding the resource available through trade, it is not clear how large a salmon resource would have been available to Kalapuyans in aboriginal times. There is evidence that Willamette Falls presented an insurmountable obstruction to migratory fish during seasonal low-flow conditions. The spring chinook run, which ascended the falls during high water in the spring, was probably the only significant salmon run which existed in the willamette River and its tributaries in aboriginal times. Moreover, spring chinook ran only in the larger tributaries heading in the Cascades (notably in the North and South Santiam, McKenzie, and Middle Fork tributaries), but apparently 
were nonexistent in the smaller and warmer tributaries such as the Tualatin and Yamhill Rivers. This does not necessarily mean that the Tualatin did not have any direct access to a salmon resource. Mrs. Ruth Roe, an elderly resident of Gaston, recalls local tradition that Tualatin men went up Patton Valley and over to the Trask River to fish while women harvested wapato at Wapato Lake; the packed earth marking the old trail was evident for years at plowing time on the Charlie Williams property in Patton Valley (on the south side of Tualatin River a few miles west of Gaston)(Mrs. Roe 1975, p.c.). The salmon resource available in the Trask River (and in other coastal tributaries) would have consisted of silver, chum, fall chinook, and steelhead runs, spring chinook runs apparently never having been well established in the northern Oregon coastal streams (cf. Gharett and Hodges 1950:3-17). Similar considerations could well apply to other Kalapuyan groups which occupied the western side of the Willamette Valley-- they too could have had direct access to a coastal salmon resource. Unfortunately, though, I have no specific information on this matter besides Mrs. Roe's few suggestive comments.

My information supporting the foregoing general picture of the salmon resource available in the Willamette River system is as follows. Some early observers state that salmon did not ascend Willamette Falls at al1. Alexander Henry (in Coues 1897:811), who passed the falls in January 1814, bluntly stated that "the salmon do not ascend these falls, the rocks being too high and the drop too steep." From other observations made by Henry on the same trip, it is apparent that. Henry travelled on the Willamette during a spell of low water. Alexander Ross, 
who was also in the area at an early time, having been associated with both the Astor and Northwest Company fur-trading ventures, commented:

To this place I Willamette Falls_T, and no farther, the salmon ascend, and during the summer months they are caught in great quantities. At this place, therefore, all the Indians throughout the surrounding country assemble, gamble, and gormandize for months together (Ross 1849:235).

Other historical data, however, clearly establish that salmon did ascend Willamette Falls, at least during high water in the spring and early summer. The Wilkes expedition, at the falls in 1841 during the spring salmon run in June, noted salmon ascending the falls in great numbers and the Indians energetically dipnetting for them:

The salmon leap the fall; and it would be inconceivable, if not actually witnessed, how they can force themselves up, and after a leap of from ten to twelve feet retain strength enough to stem the force of the water above. About one in ten of those who jumped, would succeed in getting by. They are seen to dart out of the foam beneath and reach about two-thirds of the height, at a single bound: those that thus passed the apex of the running water, succeed; but all that fell short, were thrown back again into the foam. I never saw so many fish collected together before; and the Indians are constantly employed in taking them. (Wilkes 1845 Vol. 4:344-345).

Peter Skene Ogden, in describing his passage through upper Santiam country on July 14, 1826, provides an eyewitness indication (the only one I have found) that Indians took salmon in one of the Willamette tributaries associated with a Kalapuyan group:

- . we had not left our encampment more than five minutes when we met two Indian women they appeared pleased to see us and presented us with a fresh salmon and some roots and we in return gave them a piece of deers meat which they appeared highly to prize they informed us the water was remarkably high in the Wallamitte [sic_ 7 and this $I$ belive $[$ sic_ 7 to be true as it is very seldom known that salmon are taken in the Forks we crossed last night excepting the water be very high otherwise they cannot ascend the Wallamitte $[$ sic_ 7 Falls . . . (Ogden 1950:203). 
The exceptional height of the rivers for the time of year is further borne out by Ogden's observations at Willamette Falls further on in the same trip: "I found a number of Indians assembled here it being now the season for taking salmon but they at present take but few and this the natives attribute to the high state of the water" (Ogden 1950:204).

A brief examination of the hydrology of the Willamette River may be helpful to an understanding of these early observations. The flow of the lower river at Salem goes through three distinct phases through the year. It is low during the July to October dry season, subject to frequent and extreme fluctuations from November to March or April, and levels off to a steady, moderately high flow from March or April through June (Holmes and Bell 1960:10). During the fall dry season the falls can be as much as twice as high as they are during high water. In view of the apparent difficulty with which salmon ascended the falls even during relatively high-flow periods, it seems likely that no salmon could have done so during low-flow periods.

If Willamette Falls generally presented an insurmountable obstruction to upstream fish migration from about July through October, we can draw a reasonable inference as to what runs of migratory fish occurred in the Willamette and its tributaries in aboriginal times. At the Indian fishery at Celilo Falls the spring chinook run was the first significant migratory fish run following the winter period (November to Apri1), during which there were very few migrating fish available. The next substantial run following the spring chinook was the blueback salmon run, which began as the water level of the Columbia began to drop in June; this run peaked in July. In the late summer and fall, impor- 
tant runs of fall chinook and steelhead were present, as well as a minor silver salmon run (Schoning, Merri11, Johnson 1951:8). There has apparently never been a substantial spring chinook run in the northern Oregon coastal rivers. The migratory fish resource in these streams was (and is) composed primarily of runs of silver, chum, fall chinook, and steelhead, the salmon running mainly from late summer to November, the steelhead mainly from November to April (Gharett and Hodges 1950:3-17). Assuming that the timing of the various runs of migratory fish at the mouth of the Willamette would have resembled the timing at Celilo Falls and in the Oregon coastal streams (data on the present-day timing of the various runs of migratory fish in the Columbia River system as a whole support this assumption I cf. Cleaver 1951:36-40, Cobb 1930:411415_/ ), and sssuming that Willamette Falls effectively blocked all fish migration from about July to October, it can readily be seen that the spring chinook run would have had the best access to the Willamette system. This does not rule out the possibility that other migrating fish got into the Willamette system (especially, winter steelhead in early spring or during high water periods in the winter).

At the present time, the principal spawning tributaries of the Willamette River spring chinook run are the McKenzie, Middle Willamette, North and South Santiam, and Clackamas Rivers; there are small runs in the Molalla, Pudding, and Calapooya Rivers (Galbreath 1965:29). There are no spring runs in many of the tributaries associated with Kalapuyan groups: in particular, the Tualatin, Yamhill, Luckiamute, Mary's and Long Tom Rivers. This reflects the fact that the most favorable spring chinook spawning habitat is provided by the relatively larger streams 
having their headwaters at high altitudes (cf. Hodges and Gharett 1949: 11, 16; Gibbs 1877:194). I found one definite bit of historical evidence that something like this situation existed in aboriginal times as well. Louis Labonte, an early French-Clatsop settler, cited earlier, recounted a story he says was told by Indians of the Willamette area. He calls the story "the story of the skookum and the wonderful boy." At one point in it, "wonderful boy" is asleep in a still pool in the Santiam and Coyote comes along and turns him into a rock having the form of a salmon. "And this accounts, say the Indians, for the fact that no salmon that ascend the falls at Oregon City ever turn aside into any of the streams until they reach the Santiam; but there seeing the rock, they take a circle and swim near" (Lyman 1900a:169).

The on 1y Kalapuyan informants' references that $I$ am aware of to the actual taking of salmon occur in the previously cited Santiam and Mary's River myths, which mention the spearing of salmon (tmu'waq, tmu'Cak, which Frachtenberg renders as 'fish,' 'salmon,' 'big salmon,' Jacobs as 'chinook salmon'). 
CHAPTER III

ETHNOBIOLOGY

This is intended to compile and organize ethnobiological information scattered through the Gatschet manuscripts, and to correlate this information with relevant aspects of Frachtenberg's, De Angulo and Freeland's, and Jacobs' later ethnographic and linguistic work on the Tualatin and other Kalapuyan groups. This has a linguistic as well as an ethnographic purpose: in addition to providing a synopsis of available Information on Tualatin (and general Kalapuyan) uses of plant and animal resources, it also provides a compilation of virtually all of the data available on one segment of Tualatin vocabulary, together with resemblant forms from other Kalapuyan dialects ( $I$ also include forms from other languages, particularly Chinookan, where borrowing seems evident.) Forms cited from Gatschet, Frachtenberg, De Angulo and Freeland, and Jacobs are transliterated, insofar as possible, into one common orthography; I refrain from reinterpreting authorities' phonetic recordings except to posit one-to-one correspondences between my symbols and theirs (see Appendix). Note that in this respect I deviate somewhat from my practice elsewhere in this thesis: elsewhere, I take the liberty of often writing [w] and [y] for Gatschet's $\underline{u}$ and $\underline{1}$ (Gatschet usually, though not always, writing $\underline{u}, \underline{i}$ both for the vowels and for consonantal [w], [y], and of neglecting to differentiate [I], [U] ${ }^{1}$ from their 
free variants [1], [u]); in the following (except section 9), however, I take pains to be completely accurate.

Abbreviations preceding forms identify linguistic authorities and their informants, as follows:

(1) Tualatin forms:

(P) $\ldots\left(\mathrm{e} . \mathrm{g} \cdot,(\mathrm{P}) \mathrm{am \varepsilon ^{ \prime } \mathrm { f } \cdot \mathrm { im } )}\right.$ Gatschet (1877a: 1-228), presumed to be from Peter Kenoyer.

(D) ... Gatschet (1877a: 229 400, and forms from pp. 1-228 identified as being from Dave), presumed to be from Dave Yatchkawa.

(_)... Gatschet (1877b); informant not identified.

(Emmy) ... Gatschet (1877a), from a kemkit (or Emmy) (only a few forms).

(F ...) Forms written by Frachtenberg into Gatschet's (1877a) field notebooks, with Louis Kenoyer in 1915; placed following the corresponding forms from Gatschet which they are intended to correct.

DeA ... De Angulo and Freeland (1929), given by Louis Kenoyer.

( $\mathrm{J} \ldots$...), J ... Forms written by Jacobs into De Angulo and Freeland's (1929) $\mathrm{ms} .$, with Louis Kenoyer in 1936. Forms in parentheses follow the corresponding De Angulo-Freeland forms which they correct; forms not in parentheses do not correspond to De Angulo-Freeland forms, being additions by Jacobs.

$\mathrm{J}$ (autob.) ... Jacobs (ca. 1936a), given by Louis Kenoyer.

(2) Forms from other Kalapuyan dialects.

Yam F ... Yamhill forms from Frachtenberg (1913-14c), given by Mrs. Louise Selkeah.

MRF ... Mary's River dialect, Frachtenberg (most 1913-14b, some 1913-14a), presumed to be from Hflliam Hartless, though there is sometimes uncertainty as to whether or not a form is from Frachtenberg's other central language informant, Grace Wheeler.

MRF (G) ... Mary's River, Frachtenberg (1913-14a, 1913-14b), given by Grace Wheeler (who, according to Jacobs, was not Mary's River in origin, but spoke the slightly variant Lower Mckenzie River dialect; Frachtenberg however apparently associates no dialectal differences with the two informants). 
SJ ... Santiam, Jacobs $(1928-36,1945)$, given by John Hudson. SJ(E) ... Santiam, Jacobs $(1928-36)$, given by Eustace Howard. YoncF ... Yoncalla, Frachtenberg (1914b), given by Mrs. Robert Allen.

YoncJ ... Yoncalla, Jacobs (1928), given by Mrs. Laura Blackerty Aitbertson.

YoncJ (b) ... Yoncalla, Jacobs (1935) (informant?).

In addition, I include some Kalapuyan forms cited from Hale (1846: 569-629), identified here as Hale ... . These are given without transliteration. Hale does not indicate dialect, but some forms given by him are identifiable (from morphological peculiarities) as Tualatin or Yamhill. If all of Hale's forms are from the same dialect, that dialect is further tentatively identifiable, on the basis of the word for "black bear" $/ \overline{1} 0 \mathrm{~b}-1, \#(21) T$, as Tualatin.

Chinookan forms cited here are identified as follows: L. [Lower Chinook (Boas) ... (not transliterated), Clackamas (Jacobs) ..., WascoWishram (French) $\ldots$...

\section{NATIVE TAXONOMIC CATEGORIES}

The following lists of plants and animals named by Kalapuyan informants are organized according to what seemed to me to be convenient taxonomic criteria within each area of subject matter. The question arises as to how the Tualatin themselves might have classified the flora and fauna known to them. Gatschet's texts and notes suggest some native taxonomic categorles, though they include no explicit treatment of this topic. References to some generic categories, along with examples indicating approximate ranges of inclusiveness, occur in Dave's myth text 
(1877a:240-252, in Jacobs 1945:173-178) (非, iv, ix below) and in an ethnographic text from Peter (1877a:148-152, in Jacobs 1945:187-188) (非i below). Furthermore, words more or less corresponding to familiar English generic words ("plant," "tree," "bird," and "snake"), as well as some descriptive designations for subcategories of birds and for other animals, appear in the lexical notes. These are listed below. Note that in (1) below, generic categories are formed by applying some principle of classification to the undifferentiated concept of "thing," "something," "things"; habitat was the most frequently applied such principle in the available examples.

(1) Generic expressions based upon the idea of 'thing,' 'things' (a'ka, a'gfan).

1. 'All the things in the ground' (pu'kilfan a'gfan ča ha'nkalop; ha'nkəlop 'ground, earth'). I.e., roots.

ii. 'All the things staying (living) on the land, in the country'

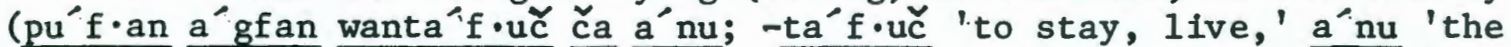
land, country, earth'). Refers to al the animals which were hunted and trapped.

iii. 'A thing with four legs' (a'ka wata'p $t \varepsilon^{\prime} 10^{\prime} /$ win; a'ka 'thing' Ising./, -tap 'four,' -10'/win 'legs'). I.e., a four-legged animal.

iv. 'All the things staying (living) in the water' (pu'kalfan a'gfan ča ma'mpka wa'ntaf.uč; ma "mpka 'the water"), "the different kinds of things in the water' (watu' 'liptin a'gfan ča ma'mpka; watu'liptin 'the different kinds of '). Includes fish, crawf 1 sh, mammals such as mink, otter, sea1, etc., and such "supernatural" beings as amhu' $1 \mathrm{uk}^{\mathrm{W}}$ and atúnkai $/ \overline{s e c} .10 \mathrm{~h}, \ldots(2),(3) 7$.

(2) Generic words more or less corresponding to English generic words.

$$
\begin{aligned}
& \text { v. 'Plant, bush' (= 'stem, stalk') (to`mpi). } \\
& \text { vi. 'Tree' (= 'wood') (awa'tik). to'mpi can also mean 'tree.' } \\
& \text { vii. 'Bird' (atwi } \left.{ }^{\wedge}\right) \text {. } \\
& \text { 'Land birds' (̌a a'nu we. nitwi' }
\end{aligned}
$$


'All water birds' (pu'f.an ča má mpka we. nitwí ${ }^{\prime}$ j). 'ocean.'

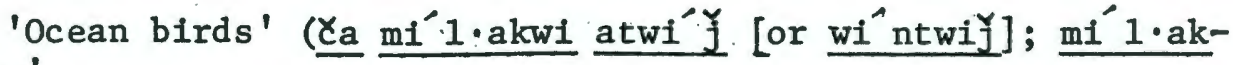

'All kinds of birds' (pu'f.an watu.'1ptin atwi' Y).

viii. 'Snake' (= 'gartersnake') (

(3) Other.

ix. 'What is eaten' (wakwaiti'kwit), 'the eatable' (akwe'iktifun) (-kwai-, -kwE1- 'to eat'). "Food," especially vegetable (e.g., roots).

x. 'Something dangerous' (aka'Skityak; -ka'šk(i)- 'bad, dangerous'). A dangerous animal.

10. FLORA AND FAUNA NAMED BY KALAPUYAN INFORMANTS

10a. P1ants $^{1}$

10a-1. Plant Names, Plants More or Less Identified

Presumed identity Tualatin and Yamhill Notes, related terms from of plant 2 terms other languages

Fungi:
(1) "Mushroom,"
(_) aka' $1 \cdot \mathrm{ap}$
SJ qa 'lalap 'mushroom'
"toadstool"
Head of
(_) to $\mathrm{m}^{\mathrm{az}} \mathrm{ak}$...
to'moz 'its head'
Cup-shaped head of

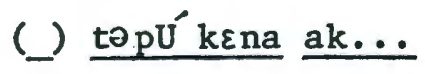
(2) "Sma11
mushroom"
(_) apU'kena
Said to mean "just arising from ground" (from -puk- 'bud,' 'flower'?).

\footnotetext{
1

Binomials follow Peck (1961) and Hitchcock et al. (1969).

${ }^{2}$ Parentheses indicate my own inference as to identity of plant in question, based upon related terms from other dialects or upon other information.
} 
(3) "Larger blue, poisonous mushroom"

(_) alu'plip

Mosses:

(4) "Moss"

(_) $\mathrm{p} 1^{\prime} \mathrm{U} \mathrm{c}^{2}, \mathrm{~b} 1^{\prime} \mathrm{U} \mathrm{c}^{2}$

YamF a tpi.'u.č́y

MRF am po. 'ičukh 'moss' $\mathrm{SJ}(\mathrm{E})$ Bu'icUk 'moss'

Ferns:
(5) "Fern"
(P) améf $f \cdot$ im

MRF am me.'fa?m 'fern' Yonc J $\overline{\mathrm{G} \wedge \mathrm{m} \wedge^{\prime} \mathrm{fi} \cdot \mathrm{mI}}$ ? 'fern'

Grasses and Rushes:

(6) (Cattail, Typha latifolia L. $)^{1}$

(P) $a g \varepsilon^{\prime} p a$

(P), (_) age'p:a

(F $\mathrm{kya} \cdot \mathrm{p} \cdot \mathrm{a})$

(D) agé pa

DeA $\mathrm{ka}^{\prime} \mathrm{p} \cdot \mathrm{a}$

( $\mathrm{G} \underline{\left.\varepsilon^{\prime} \mathrm{B}: \mathrm{a}\right)}$

"Male" part of age $\varepsilon^{\prime} \cdot a$
(P) ua $\frac{a j a^{\prime} n k u}{a \varepsilon^{\prime} p^{\prime}}$

or: (D) $a_{g \varepsilon^{\prime} p a}$ tÚ nkal

\begin{abstract}
"Flat tule;" flat leaves, thick stems, used for mats $(1877 \mathrm{a}: 32,-\mathrm{b}: 64)^{2}$; put in pads of dressed buckskin (fluff from pistillate spike put in?) for compressing the foreheads of infants (1877a: 225).
\end{abstract}

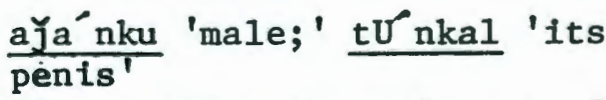

(Apparently, the end part of the reproductive stalk is being indicated; "male" and "female" perhaps refer to the round flowering stalk vs. the flat leaf.)

"Female" part of age'p.a

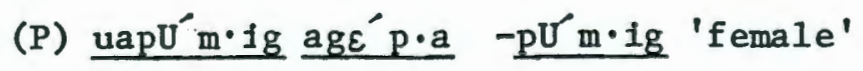

1

See footnote 2 on previous page. 2

Since Gatschet (1877a and 1877b) are cited so frequently here, these references are generally abbreviated. 
(7) "Grass"

(8) Tule, Scirpus spp.
(P), (D) alo'ko

(F 10. "qo, 10. ko)

(D) a'loko

DeA 10'ko (J $\underline{1 \mathrm{U}^{\prime} \mathrm{kU}}$ )

YamF a $\underline{\text { 1o?ko }}$

(P), (_) ha'iłai

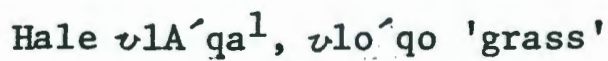

YoncJ Ga? 10.'-kwa, $100^{\circ \text { ' qwa }}$

Also means "hay."

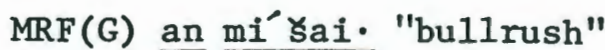
$\mathrm{SJ}(E)$ sa'i reeds, 5-6' high, used for mats (also name of mats)

YoncJ $\mathrm{G} \wedge$ 'nsai mat made of Yai (a sort of rush).

Round tule, used for mats

(1877a:32).

(Grasses or rushes, not specifically identified:)

(9) (P) akči 'tan (F k $\left.\underline{\overline{C i} \cdot \cdot^{\prime} \tan }\right)$

Cf. Wasco-Wishram (French) i-qči 'tan 'sedge" (e.g. Carex spp.) (Dr. French thinks that -tan here may be a Chinookan suffix, thus suggesting that the Tualatin word is a Chinookan loan.)

3-4', growing on lakes; sharp on sides, cuts fingers (1877a:32) (sedge, Carex spp.?).

(10) (D) $\mathrm{ala} \cdot 1$

"Thread grass" (word a1so means 'thread,' also a disease object, "worm," removed by shamans) (cf. SJ ala.' Ia 'poison power,' e.g. sent by malevolent shaman).

(11) (P), ( ) amU'stal (F) $\frac{\text { murstal }}{\text { rushes }}$

(12) (_) ha'malp
A "weed," 2-3', with tiny flowers; (perhaps) a species of Juncus or Cyperus (1877a:32, -b:64).

ha'malp anu'g arrow shaft (anu'g) of reed (hollow reed?) $(1877 \mathrm{~b}: 36)$.

\footnotetext{
writer).

A for Hale's a, a for Hale's $\underline{a}$ (due to limitations of the type-
} 
Herbs:

(13) Camas, Camassia spp.

Raw camas

Cooked camas

(14) "Carrot," wild (sp.?)

(15) (Cat-ear or mariposa $111 y$, Calochortus spp.)

(16) "C1over"

(Trifolium spp.)

(P), (D) $m a^{\prime} n t i p$

(P) ma'mis

DeA ma'mIš "roots" am.Is 'camas'

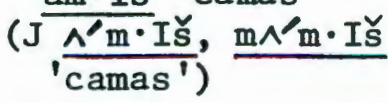

$\mathrm{J}$ (autob.) $a m \cdot a^{\prime} m \cdot 1$ š

YamF ma.'mi.š am $\underline{\mathrm{m} 1 \cdot \mathrm{x}}$

(P) amhi'uink

(F mhi.Pwink)

(D) amhI'unk $a_{m h i^{\prime} \text { uink }}$

(F hi./wink)

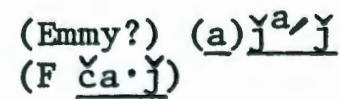

DeA cac "wild onion" ( $\mathrm{J} \underline{\mathrm{D}^{\prime} \mathrm{C}}$ ) $\mathrm{J}\left(\right.$ autob.) $\mathrm{aDZa}^{\prime} \mathrm{c}$
'- roots

(_) ha'nkueik (means 'leaves')
An important Kalapuyan staple Isee sec. 8a, 非(1)T.

MRF an $t 1 . ' p$ 'uncooked camas' SJ $-\overline{D i} \cdot \overline{P P}$, anDi.'B 'uncooked camas' (Eustace, in Jacobs |'̄928-36, 非3:135T, uses the word especially for early camas, gotten in March-early April, boiled fresh; see sec. 8a, 非(1)). YoncJ Ga'nDIPp, Di·B 'uncooked camas'

MRF am mi.'sy 'cooked camas' SJ ami.'s

(Eustace, same reference as above, uses this word especially for large camas, harvested in June and pitoven roasted).

YoncJ Ga'hmiš 'cooked camas'

Word also applied to domestic carrot. This is probably some umbellifer (Lomatium sp.?).

MRF an ca'ca? "cat-ear," white blossoms

$\mathrm{SJ}(E) \wedge \mathrm{nca}$ 'ca? "pussy-ear" (root eaten)

YoncJ $\mathrm{ca}$ ' ca? "cat-ear camas"

"A kind of camas, eatable" (1877a:89)

Cf. (P) ha'nkuik ' (large) leaves (F hankwe $\mathrm{k}$ 'leaves') 
(17) (Cow parsnip, Heracleum lanatum Michx.)
(18) Nettle, Urtica spp.

(19) Skunk cabbage, Lysichitum americanum Hult. \& St. John

(P) atu'pa

$$
\begin{aligned}
& \text { SJ antu'pa? a tall plant }
\end{aligned}
$$

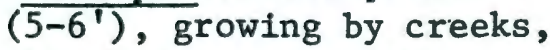

$$
\begin{aligned}
& \text { white flowers; stalk } \\
& \text { peeled and eaten raw in } \\
& \text { Apr11-May, later on made } \\
& \text { into flutes (Jacobs 1928- } \\
& 36 \text { 非4:24, 非3:139) } \\
& \text { Cf. Wasco-Wishram (French) } \\
& \text { i-du'ba 'H. lana tum,' } \\
& \text { Clackamas (J̄acobs) tuba, } \\
& \text { itu.'ba "wild rhubarb" }
\end{aligned}
$$

Stalk jointed, 1" thick, hollow, eaten when young but later gets hard; leaves wide and dentated, not eaten; grows on bottoms and creeks (1877a:170, 197). The above descriptions definitely point to H. lanatum.

\section{(_) a'mə1d ato'ftif}

This is surely a made-up name, but I am as yet unable to analyze it.

(P) ha'n·op

According to Victoria Howard (Clackamas) (Jacobs ca. 1929-30), the Santiam used (preferred to use?) skunk cabbage leaves rather than maple leaves in their camas ovens. Eustace Howard (Jacobs 1928-36 非1:60) indicated that skunk cabbage leaves were preferred over other kinds of leaves (maple, ash) for this purpose, but were not used so much due to their relative scarcity. John Hudson told Dickson (1946: 15) that skunk cabbage leaves were put immediately under and over the camas in an oven, maple or ash leaves being under the skunk cabbage; the camas was very sweet if prepared this way.

David French (p.c.) comments that various kinds of leaves, including skunk cabbage, are used by Warm Srpings women in their ovens to give flavor to camas.

(20) Strawberry, Fragaria spp.
(P) a јаa'xpə1 aja.'xpə1
(F a ca'xpul)
YamF a ca.'xquul

MRF an ca.'qoplo? 'strawberry' $\mathrm{SJ}(\mathrm{E}) \mathrm{c \textrm {a } ^ { \prime } \mathrm { kUp } \mathrm { u } ^ { \text { ? } }}$

DeA gives ca'quplo? as the Tualatin word; it seems likely that Louls, who understood central Ralapuyan, was giving the word from the 
latter.

Not dried, eaten fresh (1877a : 169).

$\begin{array}{ll}\text { (21) "Sunflower" (P) ma'ntal } & \text { (P) }\end{array}$

(Balsamorhiza

spp.?, and/or other

spp. of Compositae?)

SJ(E) Dal sunflower stalk; eaten raw, roots not eaten (Jacobs 1928-36 非3:139),

$\mathrm{SJ}(\mathrm{E}) \wedge \mathrm{nDa} / 1 \mathrm{DI}$ lka 'pya? sunflower seed ('the sunflower its-body')

Seed of

(P) aša'ual

() as.áual

MRF sa'wal 'sunflower or tarweed seeds'

SJ sa.'wal 'tarweed'

Cf. Clackamas (Jacobs)

DeA ša'wal 'sunša'wal, iša'wal 'sunflower flower' or tarweed seeds'

( ${ }_{\text {weed }}^{\text {sa'U(?) }}$ )

J(autob.) as.a-?wal Seed parched, then ground in 'tarweed seeds' a mortar; preserved for winter $(1877 \mathrm{a}: 196)$.

(22) (Tarweed, Madia spp.)

(P), (D) ato'k

MRF an məto.'qa 'sunflower'

(F ata'kh, at8q)

Yonc J GAnDu'GwA 'tarweed'

Gatschet also writes taui/y, probably taking his informants' pronunciation of English "tarweed(s)" as a Tualatin word. The plant is $2 \frac{1}{2}-3^{\prime}$ high, with yellow blossoms; the seeds are iron-greyish and sweet; they were parched and pounded in mortars (1877a: $169,345)$.

Seed of

(P), (D) ato'k

Whole plant

(D) to'mpi ato'k

(23) Tobacco (the native sp., Nicotiana multivalvus Lind1.; also, imported tobacco)
(P) ake / InUz

(F ke'/nuz)

() $k \varepsilon^{\prime}$ inIz

DeA $\mathrm{ke} \cdot \mathrm{nz}$ (J $\underline{\mathrm{ke} \cdot \mathrm{nu} \text { ) }}$

YamF ke.'nz
MRF $\mathfrak{q a}^{\prime} \mathrm{i} \cdot \mathrm{nu} \cdot z$, an $\underline{\mathrm{ka}}^{-\mathfrak{1}_{\mathrm{nu}} \cdot \mathrm{z}}$ 'tobacco'

SJ $\mathrm{ka}$ 'inu. 1 'tobacco'

Cf. Wasco-Wishram (French) i-ka'inut 'tobacco' 
Cultivated aboriginally by the Tualatin and other native groups of the area (cf. 1877a:299). Frachtenberg's (1914a) Mary's River notes give the following description of tobacco planting: "Rotten logs burned up and tobacco-seeds put in without spading. Occasionally place stirred up with stick. Each family planted for itself. When leaves ripe they pull them out and dried them."

(24) Wapato ${ }^{1}$, Sagittaria latifolia Willd. (aIso means 'potato')
(P),
(D) $\underline{\text { ma'mptu }}$
YoncJ(b) Ga'mpDu? 'potato'

DeA mo'mphto 'potato'

(J $\underline{\mathrm{m} \mathrm{N}^{\prime} \mathrm{mpDu}}$ )

"... 2" long, 1" thick, tail to it bent, hard when boiled, sweet, white inside; Sagittaria" (1877a:76)

(this describes the tubers, the parts eaten). In their corrections of Gatschet's texts, Frachtenberg and Jacobs both mistranslate ma'mptu as 'camas.' Much of it grew in Wapato Lake, and it comprised an important Tualatin staple.

(25) (Yampah or false caraway, Perideridea sp.; probably $\underline{P}$. gaird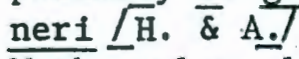

Math. subsp. borea1is Chuang and Constance)
(P) apU'hunk

White blossoms; forked roots (3-4), turnip-like, pointed, on one stem, spreading; grows in swamps (?); has a good smell; (root) eaten (1877a:169).

This Identification was based upon suggestions offered by Dr. David French.

SJ Antpo'1?čuk a kind of root having 2 or 3 parts; white flowers (Jacobs 1928-36 \#33:53)

$\mathrm{SJ}(E) \wedge$ ntBu'ičuk "a kind of camas," root 1/2" long and "shaped like a sweet potato;" much formerly grew
(P) apu'ijik

(P) $\frac{\text { poriecik }}{\mathrm{apu}^{\prime} i \mathrm{I}_{\mathrm{k}}}$

(P) a pu isik

(D) $\mathrm{apu}^{\prime} \mathrm{i} \mathrm{j}_{\mathrm{k}}$ pu'IjIk
(F pu-Pidik)
(26) (Yampah or false caraway, Perideridea sp.; probably $\underline{P}$. oregana $/ \bar{s}$. Wats.l Math.) 
DeA p’o'ycuk "wild
paŕsnips"
(J Bu'IDJUk '- root')

Smaller than apUhunk (Gatschet originally wrote "smaller than apu'ilik," then corrected "apu' 1 ' $1 k^{\prime}$ to "apU/hunk?"; the resulting reading is thus somewhat ambiguous); blossom white; root 1-2" long, dug, eaten boiled or raw; stalk 2-3', joints on; grows in prairie bottoms (1877a:196).

This term is given as the source of the name Champoeg (for which Gatschet has čampuik; an alternate name was ča či'ma pu'i çk $^{\prime}$ ).

The identification of this plant was based upon suggestions given by Dr. David French.
(27) Yarrow, Achillea millefolium I.
(P) $a_{t x u e^{\prime} n \cdot h t}$

(F $\underline{\left.\text { a tq } \underline{t} \varepsilon^{\prime} n \cdot a t\right)}$

(Presumably herbs; uncertainly identified or unidentified:)

(28) (P)

(D) $\mathrm{a} \cdot 1 \mathrm{~d}$

"Little camas;" 1' high, white blossom, grows with camas; (root) size of thumb, square around; eaten (1877a:169, 196). (Brodiaea sp.?)

(29) (_) ame'pkam

(Likely, yerba buena, Satureja douglasil (Benth.) Brig.) Also called uame 'nme'yuk لlti' 'the Indians' tea;' a wild, creeping vine, used for tea (1877b:63).

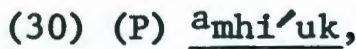

(Likely, wild mint, Mentha arvensis L.) 10-12" hi uik

() amhi'uyik high, grows in swampy places, pleasant smelling, used for tea $(1877 \mathrm{a}: 95,-\mathrm{b}: 64)$.

(31) (P) a mpl

\section{(?) cf. SJ(E) BIp a plant, I' tail, yellow flowers; stalk peeled and eaten raw; seeds mashed and mixed with tobacco to give it a nice flavor (kills bad taste in mouth or stomach) (Jacobs 1928-29 非8:139).}

(Likely, Lomatium nudicaule (Pursh) Coult. \& Rose; see below.)

Green blossom; in about May or June its stalk was peeled and eaten raw; seed not eaten; 2" (presumably, part eaten) (1877a:170, 196). 
In the Jacobs Collection, box 141, there is a pressed plant specimen identified as follows: "amBi'(?)B The leaves are eaten in spring (Santiam Kalapuya)." On the basis of a drawing made by myself of this specimen, Dr. David French positively identified it as Lomatium nudicaule (Pursh) Coult. \& Rose. If the cited Santiam name is indeed cognate with the Tualatin, this provides a clear identification of the latter.

(32) (P) $\frac{a^{\prime} n k i o \cdot f}{\underline{a^{\prime} n k i o f}}$

"Very much like a'mpi:" white blossoms, stalk eaten May or June; roots very wide spreading, used against bruises (1877a:170, 197).

(33) (P) a'ntius

Little vines growing in bunches; "wild onion;" about August (1877a:170, 196).

(34) (P) ma'mpal

"Weed," 12-15", white flowers, looks like camas (1877b:63).

Woody vines, shrubs, low trees:

(35) Blackberry,

Rubus ursinus

Cham. \& Schlecht. var. macropetalus (Doug1.) Brown
(P) a'ntkuil He ntkuil

( $F \overline{\left.a^{\prime} n t k w 11\right)}$

J (autob.) an a'ntkwil

YamF an'tkw1.1
MRF an $t k w l^{\prime} 1 \in 1 \mu^{\prime}{ }^{y}$ tkwi' $1 \varepsilon l e \cdot \mathrm{k}^{\mathrm{y}}$ 'blackberry'

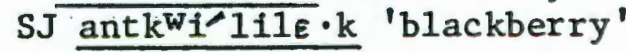

One of the kinds of berries that were dried (1877a:169). According to Eustace Howard (Jacobs 1928-36 非3:n.p.), blackberries were the best berries and were used both dried and raw; they were the only ones boiled much.
Bush of

Berry of

(36) (B1ackcap, Rubus leucodermis Doug1. 1
(P) ant... to'mpi

(P) ant... aka'yan
MRF te "pufa? "raspberry" $\mathrm{SJ}(\mathrm{E})$ DE'BUfI "raspberry" (late June-early July; eaten

Thimbleberry (R. parviflorus) might seem a possibility here (in view of the translation as "raspberry"), but the Santiam-Mary's River terms for thimbleberry are given as -tma?; tmà , respectively. 
(P), (D) at $\varepsilon^{\prime} p u f$
"raspberry"

mainly fresh; Jacobs 192836 \# $83:$ :n.p.)

YoncJ DE.'BufI "raspberry"

Bush $5^{\prime}$ high; berries not dried so often, eaten mainly fresh $(1877 a: 169,345)$.

(37) (Cascara, Rhamnus purshiana D. C.)
(P) $a p u^{\prime h u}$
(F pu. hu)

\author{
SJ amBu./ha-(DinDa/ki? $)$ \\ 'Chitum-(its-bark),' used \\ as a purgative (Jacobs \\ 1945:37) \\ Cf. Wasco-Wishram (French) \\ i-buhuqux 'R. purshiana' \\ Clackamas (Jacobs) 1buxqux \\ 'Chitum leaves'
}

Tree, about 20', black berries, white leaves (1877a:18).

(38) Cherry, wild, Prunus sp.

(P) 4 /nuI

(F $\underline{\underline{a} \text { nui. })}$

Cf. YamF ha'nog 'wild cherry'; the different words may refer to different species of Prunus.

(P) $a k a^{\prime} 1 k$

(F qa.11q)

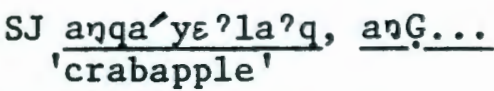

Pyrus fusca Raf.

(40) (Elderberry, blue; Sambucus cerula Raf.)
DeA $\mathrm{ka} / \mathrm{Iq}$

(J $\overline{\mathrm{a}^{\prime} \text { ? } 12 \mathrm{k} \text { ) }}$

$\operatorname{YamF} q a \cdot 1 q^{h}$

"Sour" (1877a:32). Dickson (1946:129) says that the "Calapooya Indians" (source not given, but probably John Hudson, whom she elsewhere identifies as a "member of the Calapooya tribe") "... picked the crabapple green and saved the fruit until it turned red. Then, they ate the fruit as you eat an apple today but only a few could be eaten because they were very sour and hurt the mouth. Some of the crabapples were put away in oil for winter use."

(P) $\underline{\text { ana'f }}$ 
(41) Gooseberry, Ribes spp.
(P) a'mptik

(F a mptiq)

YamF a.m ptIk amptik
(42) Hazel, Corylus cornuta Marsh var. californica (A.DC.) Sharp
Hazel nuts

Hazel bush
(P) ma'mpkui

DeA amphkwI'I 'haze1' ( $\mathrm{J}$ apGWI)

YamF ma'mpkh

(P) ma'mpik, ...bik

(F $\underline{\left.\mathrm{ma}^{\prime} \mathrm{mbi} i \cdot \mathrm{k}\right)}$
MRF pkwi.? 'hazel'

SJ ampGWi'? 'hazel nuts'

YoncJ G^'mpkwI? 'hazel nuts'

Nuts dried and eaten as wintertime food; sprouts used in basketry (1877a:61, 169). According to Eustace Howard (Jacobs 1928-36, 非3:133), the Santiam went for hazelnuts in July to early August. The nuts were picked green, taken to temporary camps, and spread on the ground to lie in the sun for three or four days; they were then beaten with a club to make the husks come off, then put into sacks and taken to the villages, where they were stored in sacks or in pits.

\begin{tabular}{|c|c|}
\hline $\begin{array}{l}\text { (43) Huckleberry, } \\
\text { Vaccinium sp. } \\
\text { (red or blue?) }\end{array}$ & $\begin{array}{l}\text { (P) } \frac{h h_{\mathrm{mo}} \cdot / \mathrm{u}}{\mathrm{h \varepsilon ^{ \prime mo }}} \\
\left(\mathrm{F} \frac{\mathrm{ha? \textrm {mu }}}{\underline{\mathrm{a}^{?}}}\right)\end{array}$ \\
\hline & YamF ha.?mo. \\
\hline Berries of & (D) $h \varepsilon^{\prime} \mathrm{mo} / \mathrm{u}$ aka yan \\
\hline Bush of & (P) to $\operatorname{mp} 1 \mathrm{~h} \varepsilon^{\prime} \mathrm{mo}$ \\
\hline
\end{tabular}

$\mathrm{SJ}(\mathrm{E}) \wedge m a^{\prime} \mathrm{u}$ a small huckleberry found near Salem; the only huckleberry picked by the Santiam (the larger kind of huckleberry being purchased from the Molala); dried for winter (Jacobs 1928-36 非83:141).

One of the kinds of berries that were dried (1877a:169, 345).

Cf, Clackamas (Jacobs) ba/čiw, izba'clu 'kinnikinnik, mt. laurel' (fresh leaves scalded in bolling water, dried, mashed, and mixed
(P) aspr-ciu

(D) ałpe 
staphylos?)

with tobacco leaves. Cf. Wasco-Wishram (French) iz-ba'čiu 'Arctostaphylos

This word seems 1ikely to be a Chinookan borrowing into Tualatin. Jacobs gives SJ $1 \varepsilon \cdot{ }^{\prime} 1$ up 'kinnikinnik.'

Grows on high ground, has rhizomes and red berries; mixed with tobacco (1877a:299).

(45) Rose, wild,

Rosa spp.

$$
\text { Larger rose hip }
$$

(46) Salal, Gaultheria shallon

Pursh

Berries of

(47) Serviceberry, Amelanchier alnifolla Nutt. var. semi-integrifolia (Hook) C.L. Hitch.

(P) $a_{m h u} / t \cdot i u$

(F hu'tyu)

(D) $a m h u^{\prime} t \cdot i u$ aka'yan

(P) ame fap

(F amblap)

(D) $a m \varepsilon^{\prime} f \cdot a p$

DeA m $\varepsilon^{\prime}$ fUm (J $\underline{\mathrm{m} \varepsilon^{\prime} f \wedge \mathrm{m}}$ )

YamF ame'Jfap

(P) al $\underline{\text { a dik }}$

(F $1 \mathrm{e} \cdot \mathrm{dik})$

() ale'idik

DeA leetIk (J $\underline{1 \mathrm{e \cdot D \text {Dik }})}$

\author{
MRF an ca'caly 'wild rose'

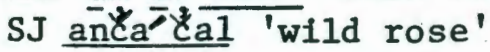 \\ 'Coyote's eye' (E'išin \\ 'coyote') \\ Cf. SJ anč' cal asni - \\ Dunkw $1 / 1 \varepsilon \cdot k$ rose coyote's- \\ eye $^{\prime}$ (= rose hip)
}

SJ(E) mU/Dui 'salal berries' YoneJ $\overline{\mathrm{G} \wedge \mathrm{mI} I^{\prime} \mathrm{D} 1 \cdot w I}$ 'sala1 berries'

Berries dried (1877a:169, 345)

MRF am ma.fom 'serviceberries' (GT) am me./fam? 'serviceberries,

Berries dried (1877a:345); wood used to make digging

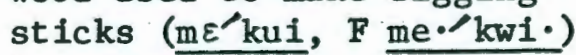
for harvesting roots (1877a: 169,195 ).

Wood used to make plates for fire drills (1877b:38).
(49) Willow

(Salix sp.)
(P) ha'mpəno.z

(F pno.1)
Willow sticks eaten by beavers (1877a:70). 
(50) (Vine maple, () ha'lot Acer circinatum Pursh)

Seed of
Yamp ha' 101 a 1 loz 'vine maple'

(_) $\mathrm{t} \partial \mathrm{ku} \varepsilon^{\prime} 1 \cdot \varepsilon z$ ha $1 \cdot 0$ I
MRF al $1 a^{\prime u}$ 'vine maple' (G?) $\overline{a l} 1 \mathrm{a} / \mathrm{u}$. 'vine maple' YoncJ Ga'nlau 'vine maple'

Has two wings $(1877 \mathrm{~b}: 63)$.

(Presumably a shrub or small tree, unidentified:)

(51) (P) ha'mpul

Broad-1eaf trees:

(52) (Ash, Fraxinus latifolia

Benth.)

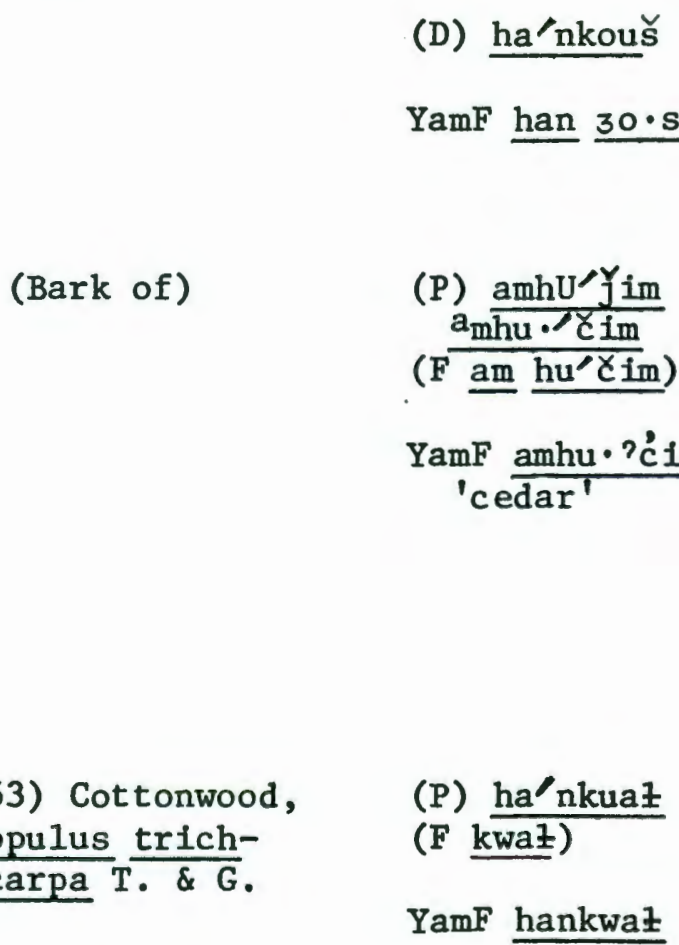

(P) ha'nkoš
(?) SJ(E) amU1 "coffee berries" (?)

"Willow in swamp, little white berries" (1877a:18). (F $\frac{\text { han }}{\text { tree }^{\text {ko.s }}}$ 'ash

"About size of ash-wood, looking like it" (?); tree on rocky hills, white leaves (1877a:280). (The foregoing leave me uncertain about the identification here.) Santiam used leaves in camas ovens (Jacobs 1928-36 非1:60；1945:18-19).

Ash bark, dried in summer (June) and used in house construction; also used to plug cracks in house walls during cold weather $(1877 a: 13,192)$. Cedar bark, $\$(56)$, is noted to have had identical use; might this somehow account for the differing Yamhill translation?

MRF an qwa. $\mathrm{L}^{1}$ 'cottonwood' (G) an gwa.z 'cottonwood' YoncJ Ga'pGWE?z 'cottonwood' YoncF ka/n kwi'/ yaz 'cottonwood ${ }^{\top}$

1

$\underline{L}=$ Frachtenberg's symbol for "surd lateral" (?). 
(54) Maple (big-

leaf maple, Acer macrophyllum Pursh)

(55) Oak, Quercus garryana Doug1.

Oak sapling or undergrowth

Acorns

\section{Conifers:}

(56) Cedar (bark?) Thuja plicata D. Don.
(D), (_) ma'nčmit

(_) ma'nšmit
MRF an 'čma? 'maple'

SJ ancm1??t 'maple' ancmi/?D 'maple' YoncJ G^/ncmI?k 'maple' G^'n⿳亠口冋I? 'maple'

Jacobs' (1928-36 \#81:60; 1945:18-19) Sant1am information indicates that maple leaves were used in camas ovens.

(P) $a m \varepsilon^{\prime} f$

(F $\underline{\underline{\mathrm{H} f}}$ )

(_) ame $\cdot \mathrm{f}$

DeA $\underline{\mathrm{m} \varepsilon \cdot f}$

YamF a $\underline{\text { mi.f }}$

(P) ač čil

(F cíčil)

(P) $a_{\text {ko'hon }}$

(F ko.'han)

DeA ko'han

(J k k han)

YamF a ko. $0_{\mathrm{n}}$
MRF am me.' fa? 'oak'

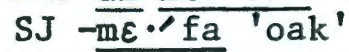

Yonc J G^ma'fa 'oak'

MRF an čl. čal bow made from oak

SJ ančl.čll 'bow,' 'oak' -ci.ck1 'bow,' 'oak'

Loan word from English?

Cf. MRF an o'lYIky, SJ

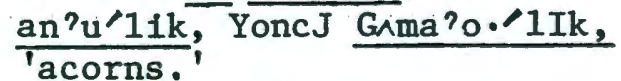

Leached and eaten in pre-reservation times I see sec. $8 a$, \#(5)T
(P) $a m a / 1 \cdot 1$ ama'1.
(F a ma/1)
MRF al 1a./h 'cedar' (The Mary's River word sug- gests that Frachtenberg may be wrong in identifying the Tualatin stem as -mal; it may rather be -al. (1) $--1 . e$. , $\underline{\mathrm{am}}-\underline{\mathrm{a}}(1 \cdot$.

Cedar bark, used in house construction and to plug cracks in house walls during cold weather (1877a: 13, 192).
(57) "Fir" (presum-
(P) ha'ntuaz ably Douglas fir, (F ha'ntwat)
Hale ho'ntawatx1 "tree," "pine"


menziesil

(Mirb.) Franco)

Fir sapling

"Leaves" of fir

(fir boughs?)

(58) "Pine" (presumably ponderosa pine, Pinus ponderosa Doug1.)
DeA ha'ntwaz "red fir"

YamF han twaz "fir"

(P) abU'fbak

(F pu'fpak)

(P) abu'f

$(\mathrm{J} \wedge$ 'mpGalk)
MRF(G?) : twa.?z "yellow fir" SJ antwa "7z "fir"
MRF(G?) am $\mathrm{pu}^{\prime} \mathrm{fa}^{h}$ fir sapling MRF am puff bow made from fir

MRF am pka1kh "red pine" (G?) pka?1k "red pine" YoncF $\mathrm{ka} / \mathrm{m}$ pka.19a?k "red pine"

$\underline{P}$. ponderosa is native to the Tualatin area, especlally to the drier eastern portion of Tualatin Plains (the present-day Beaverton-Aloha area).

(59) Yew, Taxus

(P) amI'nmiz

(F mi'nmit)

SJ ami'lmis 'yew' (wood)

Red berries (1877a:19). Frachtenberg notes, for the Mary's River, that bows were made of "hewe" wood (Frachtenberg 1914a:n.p.)

10a-2. Unidentified or Questionably Identified Plants

(60) (D) apUn:a1

A "bu11rush" (?), abundant on Wapato Lake; white blossoms; stem washed, then skin put in mouth and juice swallowed for intoxication (too much will kill men or cattle; can cause unconsciousness and issue of blood from mouth) (1877a:345).

(61)

DeA te'UwIs
"hardhack"
(J De' "was
"arrow wood;"
a small bush
used for
arrows)

SJ ta'usak 'arrow'

$\mathrm{SJ}(\overline{\mathrm{E})}$ ta'usa? 'arrow' mU-tausa hard arrowwood, for arrowheads

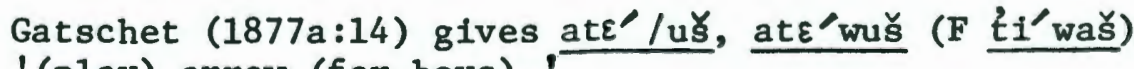


(62) J t't The absence of cognates from other dialects causes "red huckler me to be uncertain about this form from Louis, In berry"

view of the fact that Gatschet $(1877 \mathrm{~b}: 70)$ gives tu'lolu 'red,' 'purple.'

10a-3. Yamhi11 Terms for Which No Corresponding Tualatin Terms Were Found

(63) Alder, Alnus spp.

(64) "Arrow wood" (probably ocean spray, Holodiscus discolor (Pursh) Maxim.)

(65) Cherry, wild (Prunus sp.)

(66) Salmonberry, Rubus spectabilis $\overline{\text { Pursh }}$
YamF ham pup

YamF a qla.kwa

YamF ha?noq

\author{
MRF am pu. 'p 'alder' \\ Yonc $\overline{\mathrm{F}} \mathrm{ka} \mathrm{m}$ po?p 'alder' \\ MRF an qla'kwa"hard arrow \\ wood," "hardhack tassel \\ wood;" arrows made from it \\ (Frachtenberg 1914a). \\ $\mathrm{SJ}(\mathrm{E}) \mathrm{kla}$ 'gwa (miswritten for \\ kla'qwa?) a hard wood used \\ for arrows.
}

YamF 10'pqeq

MRF $10 \cdot$ 'pqe.q 'salmonberry'

Dickson (1946:83, 84) notes that the young shoots, as well as the young shoots of thimbleberry (R. parviflorus; she specifically cites John Hudson on the latter point), were peeled and eaten raw by the "Calapooya."

MRF ano'q 'wild cherry' (G?) an no' qu 'wild cherry' YoncJ Ga'? nu? 'wild cherry' Ga'?nuk 'wild cherry'

YamF hH? $\underline{\text { mi. }}$

$$
\begin{aligned}
& \text { MRF am.a "white fir" } \\
& \text { (G?) am mai.h "white fir' } \\
& \text { SJ a?ma'i 'white fir' } \\
& \text { YoncJ Ga'?mai 'white fir' }
\end{aligned}
$$$$
\text { (Abies grandis }
$$$$
\text { Lind1.?) }
$$

(68) "Yellow fir" YamF ča.'1kwal 
10an4, Introduced Plants

(69) Apple tree

(70) Beans

(71) Carrot

(72) Clover

(73) (Indian) corn, or grain of any kind
(P) a'lipom to'mpi

(P) uapa'y alI'pua

(P) amhi'uink

(_) ha'nkueik

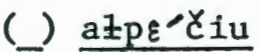

(74) Hay

(75) Oats, grain

(76) Parsnip

(77) Pear tree

(78) Potatoes

(79) Wheat
(P) alo'ko

() ala/ue'n

(P) ua'm・o amhi'uink

(P) apd' do'mpi

(P) ma'mptu

(P) $\underline{\text { sa'p111 }}$ 'ipo'm 'apple' (Chinook Jargon)

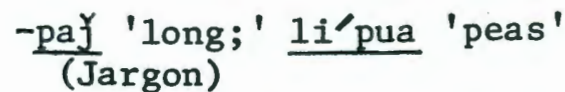

Same word as for "wild carrot," \#(14).

'leaves;' see \#(16).

Apparently, same word as for Kinnikinnik, 非(43) (resemblance of Indian corn to Kinnikinnik berries?).

'grass;' see \#(7)

Jargon

'white carrot'

p르 Jargon

Same word as for wapato; see \# (25).

Jargon 
10b. Mamma1s ${ }^{1}$

10b-1. More or Less Tdentified

Presumed identity of mammal

Order Insectivora:

(1) Mole, Scapanus spp.

(2) "Bat"

‥ Lagomorpha:

(3) "Rabbit"

(any rabbit)

(P), (D) $a t a^{\prime} 1 \cdot a$

(F $\left.\operatorname{ta}^{\prime} 1 \cdot a\right)$

(P) atkui'k

(F a tkw1kh)

(D) atkui' $\mathrm{k}^{\mathrm{u}}$

YamF tkwi'ku

(J ma'nc^z 'mole')

YamF tpu'nčat

DeA tp?'nćaz 'mole' $1 y$ given as 'gopher')

(P) atpU'ncaz

(F tponcat)
MRF an cy Icya'z 'mole'

(G) an caz 'mole'

DeA also gives, confusingly, po'ncaz 'rabbit.' Hunted (1877a:152). other languages ma'ncaz (erroneous-

Notes, related terms from

(1877a:152).

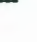


Otospermophilus beechey 1 (Richard son)

(6) Chipmunk, Eutamias townsendi1 (Bachman) J $\frac{\text { mu'waz }}{\text { squitrre1" }}$ "grey

YamP mo :az

"Grey long-tailed squirrel, on trees" (confused with Sciurus griseus?) (1877a:12). "Common prairle ground squirrel;" "grey squirrel," the smaller kind $(1877 \mathrm{a}: 152,-\mathrm{b}: 47)$. Hunted and eaten (1877a:152, 168).

Jacobs' Santiam informants both mention the roasting of this animal. John Hudson noted that it was roasted in hot ashes or coals (Jacobs 1945:27-28); Eustace Howard (Jacobs 1928-36 \#84:5) remembered seeing a man roast a grey digger against a fire.
(P) : HૃkuI

(F čkw1.'šikh)

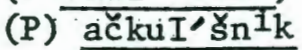

(F t tkwl's sinik)

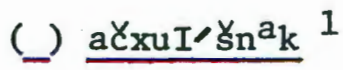

DeA kwI'skwIs

(J GwI/sGwis)

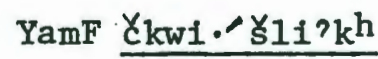

MRF kwi's'ak 'chipmunk'

(G) an kwi'še?kh 'chipmunk'

YoncJ Gw $\varepsilon \cdot / \zeta a ?$ 'chipmunk'

Hunted (1877a:152).
MRF an co'nogu "silver-tail squirre1"

SJ そu'nuk "silver squirrel" YoncJ GUmISo.'no?k "silvertail squirrel"

Hunted (1877a:152).
(8) Smal1 brown (or red) tree squirrel (Douglas squirrel, Tamiasciurus dougIas1i (Bachman' )
(P) $a p U^{\prime} z a$

(F a puz)

(P), ( ) apo'za

DeA țpo za "squirrel"

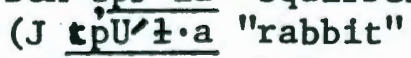
(erroneous) )
MRF (G) am po'yaq "pine squirrel"

SJ amBu' "yaq "pine squirrel" YoncJ GAmBu'yIk "pine squirrel"

Hunted (1877a:152). "Brown squirrel, small; on trees" (1877a:12); "brown, dark wood squirrel, smal1" (1877a:152); "small red squirrel" (1877b:47).

\footnotetext{
1

Interpretation of Gatschet's $x$ is sometimes uncertain, since he often seems to confuse [x] and [q]. The latter varies non-phonemically with [k] in central Kalapuyan, at least.
} 
Yamp po.'za "pine squirrel"

(9) Flying squirrel, ( ) ala'p'hi

Glaucomys sabrinus

(Shaw)

(10) Gopher,

Thomomys spp.

(P) o'ufpi

$\left(\mathrm{F}, \underline{\left.0 . f_{\mathrm{p}}\right)}\right.$

(P), ( ) $\circ / \mathrm{ufp}_{\mathrm{p}}$

(F $\circ$ uf $p)$

YamF o.fp

(11) Beaver,

Castor canadensis

Kuh1

(P) age'ipi, $k \ldots$

(F k $\overline{\left.y_{e} \cdot p i \cdot, k e \cdot p i \cdot\right)}$

DeA k $\varepsilon^{\prime} y p I$

(J G $\overline{e^{\prime} I \bar{p}}$ ?

YamF ke.?pi.

(P) Htpu's ak

(F $\left.t p^{\prime} s^{\circ} a q\right)$

(_) atpu's ak

DeA pU'saq

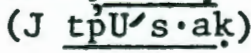

YamF tpu'saq

(13) "Field rat"

(?)

(P), (_) $a^{\prime} m k \varepsilon 1$

(P) a'mčuk

a'mpcuk

( $F$ am pcukh)

DeA a'meUk 'rat'

YamF am cyok 'rat' mo'cog 'wood rat'
(14) "Rat" (any kind), or "wood rat" (probably Neotoma sp.)
(12)
MRF a fpi? 'gopher'

SJ a $\overline{\mathrm{f} B \bar{i}}$ 'gopher'

YoncF kan fpi? 'gopher'

Hunted (1877a:152).

Hale aka'ipi 'beaver'

MRF ka'i.pyo? 'beaver'

(G) an $\mathrm{ka}^{\prime} \mathrm{i}$. pya? 'beaver'

YoncJ GAmAGa/1pya? 'beaver'

Hunted, boiled for eating

(1877a:152, 167). Pelts used in trade (1877a:111-14).
Hunted (1877a:152).

MRF an co'q 'rat'

(G) an cyo?kh 'rat'

SJ ancu" "g "mice, rats"

YoncJ GAma'čo?k 'rat'

Gimn cho?q 'wood rat'

Hunted (1877a:152). 
(15) Porcupine, Erethizon dorsatum (Linnaeus)

ㅇ. Cetacea:

(16) "Whale"

(P)

(D) aka'nis

(_) akanI's

YamF qa'niš

Eaten (presumably gotten by trade) (1877a:168). Central and Yoncalla Kalapuyan have mu./ $1 \mathrm{uk}^{\mathrm{Wa}}$

'whale,' 'whale..being' (a monstrous whale-like being inhabiting lakes and rivers). Cf. Tualatin amhu' 1 uk $^{\mathbf{w}}$ Isec. 10h, 非 (2)] qañs 'whale' (suggesting that the Tualatin word is a Coast Salish loan).
He sometimes "throws out" his bristles (1877a:88); hunted (1877a:152); quil1s
(P) ay ins
$(1877 \mathrm{a}: 162,165)$.

‥ Carnivora:

(17) Coyote, Canis latrans Say
(P) $\varepsilon^{\prime} /$ išin $\varepsilon$ sin
(_) $\frac{e^{\circ} \text { šin }}{\text { s. }}$ Es
DeA e.

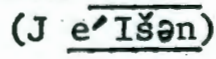
$\operatorname{YamF}$ e./ $\mathrm{Si}_{i \cdot n}$

MRF a snd 'coyote'

SJ ă̌nt' 'coyote'

YoncJ šnI

Killed, but not eaten; "the old Inds killed the coyote whenever they could though they held him to be the smartest man" (1877a:344, 375). Noted by early travellers to be numerous in the Willamette Valley (cf. Clyman 1960:136, Allen 1850:88-89.)

Hale a'melint 'wolf'

SJ amu'?lind 'wolf' YoncJ GAm^/1Int 'wolf'

DeA gives a mpmu1 ( $\mathrm{J} a / m p^{\mathrm{W}} \mathrm{UZ}$ ) 'wolf' (?)
(18) Wolf, Canis lupus Linnaeus
(P), ( ) a $a^{\prime m l i n t}$

YamF a?m 1 int $^{h}$

\section{9}


(19) Domestic dog

(20) Grey fox, $\frac{\text { Urocyon }}{\text { genteus }} \frac{\text { cinereoar- }}{\text { (Schreber) }}{ }^{1}$

(21) Black bear, Euarctos americanus Pa11as

Brown or "cinnamon" color phase

Black color phase

(22) Grizzly bear, Ursus arctos horribilis Ord

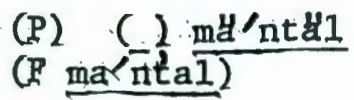

DeA ma!ntal

(J ma'ntal)

YamF mandal

(_) uap10'tim uato'ftful
Hale ma ntal 'dog'

MRF an tal? 'dog'

(G) an tal? 'dog'

SJ ante' ${ }^{\prime}$ ? 'Jog'

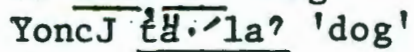

Not eaten (Jacobs ca. 1936b:12;

Tualatin and Santiam).

Said to mean 'grey bushy tail' (-plo'tim 'grey, roan;' -t-ful 'its-tail'?). A nonmade-up form is given for other dialects; cf. YamF కka'nan '(grey) fox,' \#(46).

(P) (, alU'tofan

(F lu'tifan)

DeA IU'tafan ${ }^{2}$

(J 1 U'teran)
Hale alo"tufan "bear"

(It is interesting that Hale records this form, known elsewhere only from Tualatin--the Yamhill word given for black bear $\overline{\text { I }}(45) 7$ corresponds to Centra $\overline{1}$ and Yoncalla forms.)

Hunted; pit-oven roasted whole (1877a:152, 167).
(P) uapo'ziem ald...
-po'ziem 'brownish-red'
(F po'teyim $\cdots$ )
(_) uamo'yim ald... -mo'yim 'black'

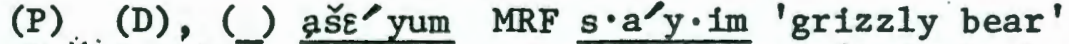
(F $\underline{\left.\underline{s} \varepsilon^{\prime} y \mathfrak{l m}\right)}$
(G) an sa'yim 'grizzly bear' SJ asa'yum 'grizzly bear'

1

The fact that there seems to be no word in any of the dialects denoting the red fox, Vulpes fulva, may bear out the conclusion of mammologists (cf. Ingles 1965:347) that red foxes were introduced into western Oregon from the eastern U.S. (although the race found in alpine areas of the Cascades is thought to be native). (Frachtenberg gives MRF kwIni.' $f$ Isee \#(24)T, 'fox,' 'coon,' 'cat,' 'otter'-ra term apparently belng very Toosely used; Jacobs gives YoncJ G^mA'ye.'BI 'fox,' a term which I am unable to elucidate further.)

$$
\underline{\underline{A}}=\text { DeAngulo-Freeland's a (as in French "patte"). }
$$


DeA ě̌"yems

(J se.tygm)

YamF a še.m
YoncJ కa'yu・rmo? 'grizzly bear ${ }^{\top}$

Cf. L. Chinook (Boas) -cā'yim 'grizzly bear'

Wasco-Wishram (French) 1-sayam 'bear' (not the usual name, according to Dr. French).
(23) Raccoon, Procyon lotor (Linnaeus)
(24) (Fisher, Martes pennanti /Erxleben/.)
(P) $\frac{\text { a'mpkuin }}{\text { a'nkuin }}$

DeA a pkwen

(J $\overrightarrow{a n k w n)}$

YamF an kwi.n

(_) amo./s "black

YamF møs 'fisher'
MRF an kwin 'raccoon' SJ a $\vec{\eta} k w_{1 / n}^{\prime}$ 'raccoon' YoncJ kwI.'nI 'raccoon'

Hunted and eaten (1877a:152, 168). Haired skins used in interlaced blankets, for caps, etc. $(1877 \mathrm{a}: 162,164-65,337)$.

(25) Weasel (Mustela erminea Linnaeus and or M. frenata Lichtenstein)

(P) atIlpIli/di

(F $\mathrm{t}^{\mathrm{K}^{\prime} 1 \mathrm{p} 11 \mathrm{id}}$ )

(_) atilpIlhI/di

(26) "Larger mink" (probably Mustela vison Schreber)I

(_) akUI'n.Uf

SJ anGwi'ni-f 'mink'

Frachtenberg translates MRF kwInl. f, variously, as 'coon,' 'fox,' 'cat,' ''otter,' and additionally gives kwI'nfin 'weasel.' However, according to

\footnotetext{
"Larger mink" could also refer to one of the species of the genus
} Martes (marten, fisher); however, if the word given by Gatschet's.informants as 'mink' / $\#(42) T$ is really muskrat, as seems $11 \mathrm{kely}$, the $\mathrm{kU} / \mathrm{n}$.Uf is likely Mustela vison, in conformity with Jacobs' Santiam translation. 
Jacobs, John Hudson insisted that SJ anGwi'n1.f means 'mink' (i,e,, presumably Mustela vison). Frachtenberg's informant had forgotten some names of animals, and must have been using this term loosely.

(27) "Polecat" (Spotted skunk, Spilogale putorius (Linnaeus) )

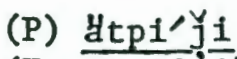
(F a tpinci)
(P) atpI'c
(F $t \overline{\mathrm{p} I \mathrm{C}}$ )

YamF tpi.?c "polecat"

\section{YoncJ G^m^ce/"pca? "sma11 skunk"}

DeA has, rather questionably, spI'cI ( $J$ sBICे?n) 'weasel' (questionably translated).

Trapped (1877a:152). "Polecat" (1877a: 63, 152, 207); "skunk, 1ittle speckled" (1877a:12). (P) $\frac{\text { ma/ntx }}{u}$ p,
MRF an tku.p "skunk"
Trapped; caps made from its
(F ma/ntqup)
fur (1877a:152, 162).
(P), (D) ma/ntkup ${ }^{1}$

(striped skunk, (Schreber).)

DeA ma'ntkUp

(J ma'ntGUp)

YamF man tqop

(29) "Otter" (river otter, Lutra canadensis (Schreber)
(P) ala'uč Inక̌an

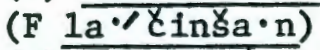

(P) alU cinsan, alo!..

(_) alo’pčInsan

YamF an no. čínzal 'Iand otter' (an no. 'Iand')
MRF a ya / toncya? ${ }^{\text {h }}$ "otter" Yonc $\bar{F}$ sl'nsa.lah "otter"

Trapped by the Tualatin; pelts used in trade and for ceremonial regalia (e.g., shamans' decorated belts, worn over the shoulders) $(1877 \mathrm{a}: 152,111-14,358-60)$.

${ }^{1}$ Gatschet's $x$, k (the latter written "k" as opposed to " $k$ ") appar-

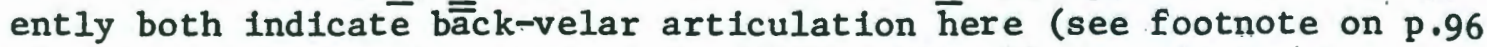
of this section). Gatschet notes (1877a:389), "k in ma'ntkup \& many other words a little differing from the common $k$, but not Iike Klamath $k$;" however, I find this: "k" recorded only a very few times. 
(30) "Sea otter," "seal"

(31) "Cat"

(generic?)

(32) Mountain

lion, Felis con-

color Linnaeus

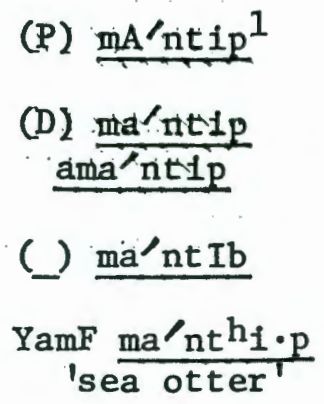

(P) aua'šiš

(F a wa'sis)
YamF wa/šis

"Sea otter" (1877a:114, -b;46); "as big as grizzly" (1877b:46; suggest1ng sea lion rather than otter); "seal" (1877a:244). It seems possible, in view of the inland orientation of the Tualatin, that the vague translation of this term reflects correspondingly vague denotation. Pelts were wealth articles (1877a:114).

I found no indication of a more specific application for this term. In fact, it appears to be a loan from Yakonan (cf. Alsea /FrachtenbergT wa.'sis 'cat;' $\underline{\text { s }}$ nom. suffix).

(P) ha'muš

(P), (D), ( ) ha'mhuš

MRF an hu.?c 'mountain 1ion' SJ anhu' $\mathrm{c}$ 'mountain lion' YoncJ Ga'hmU?s 'mountain Iion

DeA a/mhUš

( $\mathrm{J}$ a $\overline{\text { (mhUS) }}$

YamF ha'm hus $\mathrm{a} / \mathrm{m}$ hus

Hunted, boiled for eating (1877a:152, 168, 245). Dressed hides with hair left on (Sto'lak 'dressed hide/With hair left on T') used as blankets; intact hide from head for cap (1877a:161-162).

MRF an ye."kwa "wildcat" YoncJ nI."Gwa? "wildcat"
(33) "Short-tailed wildcat" (bobcat), Lynx rufus (Schreber)
(P), (D) an $\varepsilon^{\prime} \mathrm{g}^{\mathrm{u}}$ ( $\mathrm{F}$ ni'ku)

YamF a $\mathrm{ni} \cdot \mathrm{k}^{\mathrm{u}}$ an $\underline{\text { ni.ku }}$ "wildcat"

"Large, stripped wild-cat, short tail;" hunted and eaten $(1877 \mathrm{a}: 152,168)$. Skins used in interlaced blankets, for wealthy people; poor people's children might clothe themselves by merely tying the skins around themselves (1877a:164-65). 
(34) "Seal"

(probably harbor

seal, Phoca vitu-

Iina Linnaeus)
$(P 2,(D)$ aud IXE1

(P walqa ${ }^{1}$

() aud $1 \times 1$

YamF wa'1xayu.

Seals were sometimes taken by the Tualatin in the Columbia River (1877a:344); they were bolled for eating (1877a;168). David Douglas (1904त05 ..... 3:251), writing in 1825 , noted that Phoca vitulina was abundant in the Columbia.
MRP an u'Ixayu " "seal"

Cf. L, Chinook (Boas) - 'Ixaiu "seal"

o. Artiodactyla:

(35) Elk, Cervus canadensis

(Erxleben)
(36) Black-tailed deer, Odocoileus hemionus columbian nus (Richardson)

Opposite sex (?)
(P) $a^{\prime}$ ntxi, $\ldots$ tki ( $F$ a $\underline{\text { ntq1.) }}$
(D) $a^{\prime} n t k$
() $a^{\prime} n t x$
DeA $\mathrm{h}_{\text {antk }}$
(J antkt

YamF antg

(P) atu'nkəta

(F tu'nkta)

( ) atU'nk'ta
(P) $a^{\prime} m p I$

(F $\underline{a}$ mi.)
Hale a'ntuqu 'elk'

MRF an tqa? 'elk'

SJ antga'? 'elk'

YoncJ G^ntGa? 'elk'

Hunted, meat boiled or roasted fresh, or dried for winter $(1877 \mathrm{a}: 152,167)$. Articles of clothing, blankets made from dressed hides (1877a: 161).

Name possibly analyzable in terms of kta 'ear' (referring to the conspicuousness of the ears?).

Hunted and eaten (1877a:152, 168).

SJ 1 mP्P.? 'black-ta1led deer'

tu'nkta and a'mpi apparently distinguish male and female; however, one text (1877a:152) translates the former as 'female' and the latter as 'male,' while

${ }^{1}$ I question Frachtenberg's correction of Gatschet's $x$ to [q] here, in view of the related terms cited from other dialects and from Chinookan.

2 In this case Frachtenberg's correction of $x$ to [q] seems correct. 
another (1877a;168) translates the former as 'male,' the latter just as 'blackntalled deer.' A simple error must be Involved, but I have found no independent information by which to set things right.

(37) Whitertailed deer, Odocolleus virginianus leu curus (Douglas) (a1so, probably, 'deer,' generic)

White-tailed buck deer

White-tailed

female deer

Fawn
(P),

(D) $a t a^{\prime} 1 \cdot i m$

Hale ata/1im "deer"

() $a t a^{\prime} 1 \cdot \partial m$

DeA ta' 1.Im "deer"

(J $\overline{\left.\mathrm{D}^{\prime} 1 \cdot \mathrm{Im}\right)}$

YamF a ta.'11.m

"deer"

This, the native subspecies of 0 . virginianus, while now of very limited distribution in our area, was formerly widely distributed and abundant in western Oregon.

Hunted and used as food (1877a:152, 168).

Hides tanned (aui'čel 'buckskin;' ašto'lok 'tanned hide ( with hair left on T'), used for clothing and blankets; intact skin from head (ears left on) for caps $(1877 \mathrm{a}: 161)$.
(P), ( ) aua $\mathrm{a}^{\prime} 1$

(F wa/yi.)

() aud/i aua 1

YamF wa' $y i \cdot h$

"buck deer"

P1ural: (P) awa/yašt

Or: (_) $a^{y} a^{\prime} n k u$ $\operatorname{ada} \overline{1} \cdot \frac{\mathrm{a} m}{\mathrm{~m}}$

(_) acpU/m.aik

YamF cpu'mai.q "doe"

Or: (P) $\mathrm{apU} / \mathrm{m} \cdot 1 \mathrm{~g}$ ada $1 . a_{m}$

(P), (D) aplo/uf

(F ṕlo.f)

C ap1U/e
Frachtenberg also gives

YamF a wa'yi. 'antlers,' corresponding to Tualatin

(Gatschet) tua/1 (tu-wa/1 ?) 'antlers.'
- ja'nku 'male'

-pu'mig 'female'

MRP an p'a'lafo 'fawn'

SJ Anpa-lafI 'fawn' 
(38) Antelope, Antilocapra americana (Ord)

(39) Bison, Bison bison (Linnaeus)

(40) Mountain sheep" (mountain goat, Oreamnos americanus TBlainvilie/)

\section{(L) uayamร1-YE1 at $a^{\prime} 1 \cdot$ In}

'the yariegated deer' (-yams1- JE1 "variegated, speckled')

This maderup form must reflect the fact that anter lopes were peripheral to Tualatin experience.

\section{() uamuntmécyuk amư šmuš}

\begin{abstract}
'The Indians?...cow' (-mh'nme(1)'Indian;' -múšmuš 'cow, Jargon). (Another anlmal which must have been peripheral to Tualatin experience.
\end{abstract}

(P) $a$ ambu'm $\cdot \mathrm{o} / \mathrm{u}$

(F) hu० m

(P), ( )

Woven ("braided," "twisted") wool used in clothing and blankets, specific mention being made of its use in the dress of wealthy women (1877a:164-65). The dressed wooly skins of this animal (which along with dogs constituted the only native source of woolly fiber), as well as blankets woven from its wool, were reported by Lewis and Clark on the lower Columbia River (Bailey 1936,61). There is some uncertainty as to whether mountain goats ranged south of the Columbia River (into the Oregon Cascades) in Lewis and Clark's time (cf. Balley 1936:61-62); they certainly did inhabit the Washington Cascades, e.g. around Mt. St. Helens. Since in any case goats would not have ranged into Tualatin territory, the Tualatin must have gotten wool by trade. There is no Indication as to whether the Tualatin wove wool themselves.

10b-2. Ident1fication Uncertain

\footnotetext{
(41) (P), (D)

aku $1 \cdot a$

(F ku/1.a)
}

(?) SJ(E) Gula'ta a mythological person who made San tlam Gap (originally a low tunne1).

(?) MRF(G) gollata? "weasel"

Cf. (?) Clackamas (Jacobs) gu'1yu "woodrat"

Wasco (Curttn) kula "possum" 
(Possibly mountain beaver, Aplodontia rufa /Rafinesque T.2

Hunted; "kind of otter, thick fur," "in water," "black \& reddish fur" (1877a:152) (the latter description is a note from Dave to one of Peter's texts, and is written over the following, which is apparently based on the original translation from Peter: "kind of gopher," "opposum?"). "A kind of otter, size of skunk, thick fur" (1877a:282); "water animal," high-priced braided blankets made from it (atu's.ai, made from strips of fur sewn together) $(1877 \mathrm{a}: 162,164)$. In the Powell form, this animal is further identified (according to the printed listings on the form) as "ground-hog" and "opposum" (1877b:46, 47; Gatschet questions, "?" the reference to opposum).

The only possibility which seems to me to account for the contradictoriness of the above is the so-cailed "mountain beaver," Aplodontia rufa. which, although not now of any economic importance as a fur-bearer, is known to have been used as such aboriginally in the area (cf. Bailey 1936:227). There is a difficulty in this identification in that the Aplodontia, though a good swlmmer (e.g., Balley, $1936: 226$, cites a case of swimming mountain beavers being mistaken for muskrats) and frequently a resident of stream banks, is a seemingly unlikely candidate for being considered a water animal. However, it is a burrowing animal (hence the vague allusions to "gopher," "ground-hog"?), and it may well have been formerly better represented near low-elevation bodies of water such as Wapato Lake (one side of which, called $\mathrm{K}_{a}-\mathrm{ku}^{\prime} \mathrm{l} \cdot \mathrm{a}$, was named for this animal). Furthermore, it is a 11ttle-observed, 1ittle-known animal, of peculiar habits, completely unique to northwestern North America; Gatschet (also Frachtenberg, Jacobs, and Curtin, if it is the case that the Santiam-Mary's River and/or Chinookan terms are indeed related) likely had no knowledge of $1 t$.

The only other candidate that I can think of, considering size, fur-bearing value, and the fact that most other valuable fur-bearers seem to be spoken for already Isee $\#(24)-(30) T$, is the muskrat, Ondatra zibethica. However, the central language terms for the latter, $\mathrm{SJ}(\mathrm{E})$ ' $\mathrm{mU}^{\prime} \mathrm{GUp}, \mathrm{MRF}$ am ' $\mathrm{mu}^{\prime} \mathrm{s}^{\mathrm{y}} \mathrm{ku}$ ? $\mathrm{p}$, seem entirely unrelated to the Tualatin word in question. Also, it seems to me that although Ondatra would surely be identifted as a water animal, it would be unlikely to be referred to by vague allur sions to "gopher," "ground-hog," "opposum." 
(42) (P), (D) atmI'ntku (F tmi'ntku)
Cf, Wasco-Wishram (French) tmentku, Imintku 'muskrat'

Chinook Jargon $\varepsilon m I$ 'ntopu

'muskrat'

(Possibly muskrat, Ondatra zibethica /LinnaeusT.) Given by Gatschet as 'mink' Tbut see \#( $\overline{2} 6) T$. I speculate that Gatschet's informants were rea'ily referring to the muskrat (which, like mustela vison, is a small, valuable fur-bearing animal). This possibility is given some weight by the absence of any other word for 'muskrat' (the word a'mpčuk, given in the $1877 \mathrm{~b}$ ms. for 'muskrat,' is merely the word for 'rat'). Might the phonetic resemblance between -mi'ntku and English "mink" be responsible for the apparent confusion in translation?

(43) (D) aui'kiaks A "kind of otter;" one of the kinds of things "living in the water" (1877a:244).

(44)
(P) auI'nhi
"Wild dog, fabulous;" hunted (1877a:152).

10b-3. Yamhil1 Terms for Which No Corresponding Tualatin Terms Were Found

(45) Black bear, Euarctos americanus
MRF no. ${ }^{i}$ ta 'black bear'

(G) an no./ita? 'black bear' SJ a?nu'ite 'black bear' YoncJ Ga?nE./wIta? 'black bear $^{\top}$

A quite distinct Tualatin

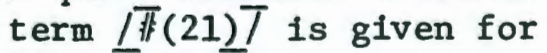
this animal.

MRF ske'n SJ asGe/nan 'grey fox'
(46) "Fox" (grey YamF ška'nan

fox, Urocyon cinereoargenteus)

(47) "Rabbit"
YamF ham pun
MRF am pun? "rabbit"

$\mathrm{SJ}$ amBu/n "rabb1t"

A quite distinct Tualatin term 非(3) $\bar{T}$ is given for "rabbit." 
(48) Sea I1on

Yamp am múša.yim

MRF am mu'ša,yım 'sea 11on'

YoncF muša.'yum 'sea 11on'

10b-4. Introduced Mammals

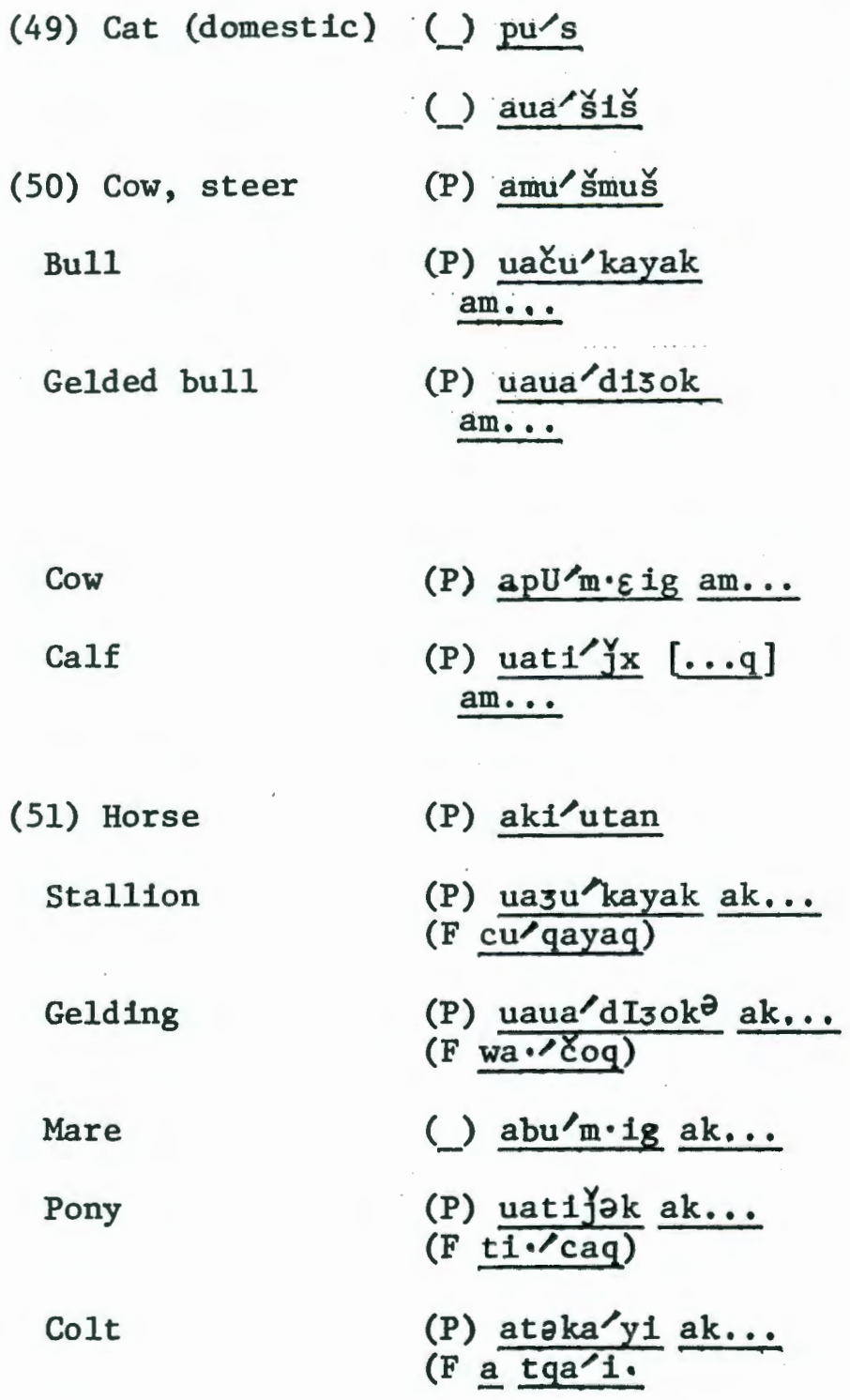

(52) (House) mouse;

(_) ča ha $\mathrm{a}^{\mathrm{m}} \mathrm{m} \cdot \mathrm{i}$ $\frac{\text { ue TItpu's.ak }}{\text { (or atpi...) }}$

Mus

(53) Mule
Jargon

See $\sharp(31)$

Jargon

$\frac{\text {-čuk- 'testicles,' -yak }}{\text { (suffix) 'having! }}$

Sald to mean 'out of stones' (possibly: wa- adjectival, -wa?- 'not, '- (i)-3ok 'itstesticles').

-pu'm... 'female'

-t1'yq 'smal1'

Jargon

(see above) ča h... 'In the house,' tp... Same word as for native mouse.

\footnotetext{
'Longreared ..horse' (-po\}'long,' tun-kta '1ts ears')
} 
(54) Rat; Rattus

spp.

(55) Sheep

( ) $\frac{\text { a } 11^{\prime} m \cdot o t o}{\text { mouto'n" }}$
- -čk same as native rat.

Jargon

10c. Birds $^{1}$

\section{0c-1. More or Less Identified}

Presumed identity of bird

Shore and Water Birds (About Six Orders):

(1) (Probab1y, grebe; perhaps pied-billed grebe, Podilymbus podiceps IInnaeus ()
(2) "Swan" (olor sp.)

Notes, related terms from other languages
In water, smaller than duck, "diving a11 the time" (1877a: 40); "lives in creek, on fishes" (1877a:77).

$\mathrm{SJ}(\mathrm{E}) \mathrm{G} \mathrm{U}^{\prime} \mathrm{GU}$ bird 11ke swan, but different (?)

DeA qग/hU1, glven as 'swan,' should be translated as 'crane' I see \#(10)/.

MRF tqo.'taq 'goose' $\mathrm{SJ}(\mathrm{E}) \mathrm{kj}$ Dak 'goose' YoncJ kuldikk 'goose'

Biggest wild goose, black (1877a:38); eaten $(1877 a: 168)$.
(3) "Goose" (11kely a race of Canada goose, Branta canadensis Iinnaeus /)
(P) atko'dək at ko'dIk atxo-dək [atq...] ] ( $F$ tqo?taq)

DeA tqo'taq 'goose' ( $\mathrm{t}$ Go.'DAk)

(Frachtenberg notes Yamhi11 term same as for MR; see opposite)
(4) "Goose" (another race of Canada goose?)
(P) awI'wak aui /uәk
(F wi.?wik $)$

Middle-sized black goose, white spots (1877a:38); smallest goose, end of wings black, eaten (1877a:168).

${ }^{1}$ A number of manuals were consulted for this section, especially Robbins, Bertel, Bruun (1966) and Gabrielson and Jewett (1970). 
(5) "Goose" (sp.?)

(6) "Duck" (generic)

(7) A type of duck (sp.?)

(8) "Smallest duck" (sp.?)

(9) Great blue heron, Ardea herodias (Linnaeus)
(P) atk $\varepsilon^{\prime} i /$ uaks

(F a tkwi-wak ${ }^{h}$ )

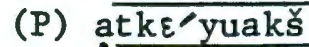

(F tke.'waks)

(P) a'mpiuk

(F am pyu? $\mathrm{k}^{\mathrm{h}}$ )

DeA a'mpyuk

or: naqnaq

( $\mathrm{s} \wedge$ 'mpyuk)

YamF a.'m pyoq
Size of awi'wok, white and black, mostly white (1877a: 38); black-winged, eaten (1877a:168).

Hale v'mpiu'k 'duck' MRF na'knak 'duck'

YoncJ G^'mpnnk 'duck'

Eaten (1877a:168).

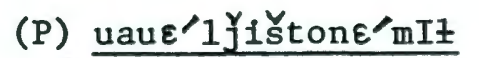
(a'mpiuk ?)

(P) atmU jxapo.

(P) atxua'ištxuais [atq...tq...]

DeA, qwa'sqwas "crane" ( $\mathrm{J}$ kwa'skwas)

YamF tqwa'sqwas "swan" (?)

uaue' 1 ... 'their heads are gold-shining' (-uع'ly̌lštošt'gold-shining,' -nع-miz 'their heads').

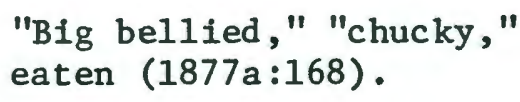

MRF qwa'sqwas "crane"

(G) an kwa.? skwas "blue

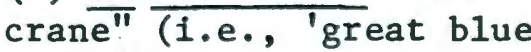
heron')

SJ ang'wa'sq'was "crane" Boas gives L. Chinook iqoā'sqoas "crane," but -qjo'askioai or é '́qulqu1 "heron."

Cf. Clackamas (Jacobs) $1 \mathrm{q}_{\mathrm{W}} / \mathrm{sq}^{\mathrm{W}} \mathrm{as}$ "crane."

Wasco-Wishram (French) 1-q́wašq́waš, 1 -gwwašqwaš "crane"

"Crane" here (at least in most of the above occurrences) must reflect loose popular usage--the great blue heron is of ten popularly so referred to.

(P)

(F tgra1)

( ) $a_{\text {tko }} \cdot 1$

DeA go'hu1 "swan" (?) (J $t$ GJ.1)
MRF an go' $1.0 \mathrm{q}$ "white crane" (1.e., 'sandh111 crane')

$\mathrm{SJ}$ (E) $t \mathrm{Gu} \cdot 1 \mathrm{la}$ white bird resembling goose; with long neck; has good eyes; two always go together. 

Cf. (?) L. Chinook (Boas) équlqul "heron"

Grey in color, formerly many here, lays only two eggs (1877a:40); about 3' (1877a:51).

(11) "Snipe"
(common snipe,
Capella gallinago
ILinnaeus/?)

(12) "Sea gull"

(13) (Belted kingfisher, Megaceryle alcyon /Linnaeus/)
(P) ma'nč Ik
ma nčak
ma'nciok
( $F \overline{\text { ma/ncyeq) }}$

According to Dave, this is identically the same name as that for the red-shafted flicker / 非(23)T. The wing feathers are reddish and were used (in ceremonial regalia) (1877a:115).

'Sea buzzard' (-mi'l-ak-
'ocean, '-tif 'turkey vulture')
(P) ča $\mathrm{mI}^{\prime} 1 \cdot \mathrm{akui}$ (a $)$ tIf

(F $\overline{\text { mi }} \overline{\text { lakwi. }}$ tif)

P1.: (P) ča m... ui'ntif

\section{(P) $a a^{\prime} 1 \cdot a 1$ \\ (F ça $\mathrm{a}^{\prime} 1 \cdot \mathrm{a} 1$ )}

(Frachtenberg notes that the Yamhill term is identical to the MR term opposite)
MRF $c^{y_{a}^{\prime}} 1 a l$ 'kingfisher'

"Little blue bird in creek, jumping into the water" (1877a:40).

(Shore or water birds, specific identification uncertain:)

(14) (P) acua/šnIk

( $F$ čwa/

$$
\begin{aligned}
& \text { MRF an ćwa?s 'snipe' } \\
& \text { SJ (E) ¿wa/?s bird somewhat } \\
& \text { resembling crane (?), but } \\
& \text { smaller. }
\end{aligned}
$$

Lives on the water, in swamps, 1ittle, 1ong-legged (1877a:40).

(15) (P) amI' $1 \cdot$ akiuk (F mílaqyuk)

(16) (P) amU/nkUzo (F mu'nkuz "jacksnipe") -mi'1.ak- 'ocean.' Ocean bird, "1ike goose" (1877a: 41).

Swims on lakes, size of rooster, grey, looks like snipe (1877a:40). 
"Game Birds" (ㅁ. Galliformes, ‥ Columbiformes):

(17) Grouse (Sooty
or blue grouse,
Dendragapus
obscurus (Say 7 )

(18) "Pheasant," "prairie chicken" (probably ruffed grouse, Bonasa umbellus /Linnaeus T; also, domestic chicken).
() $a^{\prime}$ muf

DeA $\quad a^{\prime}$ mUf

MRF a mu'f 'grouse'

SJ amu 'grouse'

YoncJ $\overline{\mathrm{GN}^{\prime}}$ mUf 'grouse'

YamF aunf (miswritten?)

Grouse, grey; eaten (1877a:52, 168). My selection of the blue grouse over the

ruffed as the likeliest candidate here partly depends on the identification of the latter given below. Also in favor of this identification: the indicated grey color, and a passage in Jacobs' Santiam texts (1945:34), in which it is indicated that if it snowed hard in the late winter, at the time when the grouse (amu'f) "sang," it was attributed to grouse's power-song and not considered important-"late winter" would seem more or less to correspond with the onset of the blue grouse's distinctive mating call (late February or March, according to Gabrielson and Jewett 1970:210).

Frachtenberg's Mary's River informant, William Hartless, indicated (Jacobs 1945:349) that it was a sign of bad omen when grouse came to a house.

(P) a'ntmat

(F a n tmat a nth ha?t)

DeA ?a'ntmat "Indian

YamF an tmat ${ }^{h}$
MRF me'nmayuk an $\frac{t^{\text {hmat }}}{\text { 'Indians' chicken' (me.n... }}$
'Indians' /poss.7)
SJ antma'?t "pheasant"

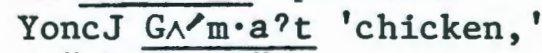
"pheasant" G^'ma?t 'chicken,' "pheasant"

Aboriginal (ua me'nmeyuk a'ntmat 'the Indians' chicken, "pheasant"'). Hunted and eaten (1877a:152, 168). An older manual of the birds of the U.S. (Pearson 1936, Pt. 2:17) gives the following as some of the common names of the ruffed grouse: "partridge," "pheasant," "drumming pheasant," "mountain pheasant." It is further indicated that the name "pheasant" was in use for this bird particularly in the middle and southern states. I infer that Kalapuyan informants picked up the name "pheasant" from early settlers, many of whom came from the relevant sections of the country. Dr. Richard Forbes (1976, p.c.) also pointed out that the ruffed grouse is more chicken-like in appearance that is the blue. Historical data on distributional patterns of Oregon birds suggest only three or four chicken-like or "pheasant"-like birds which likely would have been 
native to the Willamette Valley area: blue grouse, ruffed grouse, mountain quail (\#) (19).7, and possibly valley quail (cf. Gabrielson and Jewett 1970:207-227) -rthus, my reasoning here is based partly on a process of elimination. William Hartless (in Jacobs 1945:349) indicated that it was a sign of bad omen when the a'ntmat came to a house.

(19) Quail (probably mountain quail, Oreortyx picta palmeri /oberholser / $^{1}$
(20) Pigeon, wild (band-tailed pigeon, Columba fasciata Say)
(P) a/uile'ak

(F wi'la?yaq)

(P) auI'ləyak

(F wi'la waq) $^{\prime}$

(_) awi'1Eyak

YamF wa'ye $k^{h}$

(P) amonge/ya

(F ami'ngi-ya)

(P) amI'ngeya

(F mi'ngi-ya)

YamF am (h) $1 \cdot /$ nqaya
MRF a wa'ye? $\mathrm{k}^{\mathrm{h}}$ 'qua11'

(?) MRF cyaha1.k 'quail'

(other species?)

(?) SJ Ěa haik 'qual1'

Good to eat $(1877 a: 38)$.

Hunted and eaten (1877a:152, 168).

MRF wi./ $\mathrm{n}_{\text {ko }}$ 'dove'

(G) a wi./ngo. 'dove'

YoncF wi./ngo.' 'dove' (also said to mean 'pigeon')

Grey (1877a:40).

DeA wI'Ako 'dove'
(J wi'nku "pigeon")
(P) awUnko'

(D?) a'winko dove, Zenaida mac-
roura Linnaeus//

‥ Apodiformes:

(22) "Hummingbird"

$$
\begin{aligned}
& \text { (_) adI'gəna } \\
& \text { DeA ta'kana } \\
& \text { (J D D } I^{\prime} \text { Gana) } \\
& \text { YamF di.'gnah }
\end{aligned}
$$

MRF $t I^{\prime} k y_{\text {Ină }}$ 'hummingbird'

(G) an ti/kyine. 'hummingbird $^{\top}$

$\mathrm{SJ}(\mathrm{E}) \wedge \mathrm{nDI} / \mathrm{GInI}$ 'hummingbird'

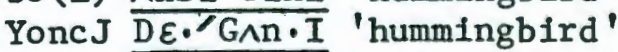

(B) GanDE:/Ga'nI 'hummingbird'

1

The valley quail, Lophortyx californica vallicola (Ridgeway) is possibly also indigenous to the Willamette Valley, though its widespread introduction into the valley since about 1870 has obscured the original distributional pattern. 
‥ Piciformes:

\section{(23) "Woodpecker" (red-shafted \\ flicker, Colaptes auratus cafer IGmeling/)}

(25) "Woodpecker, red-headed" (red race of yellowbellied sapsucker, Sphyrapicus varius ruber /Gmelin/?)
(P) ma/nčiok

( $F$ ma/ncyeq)

(D) ma'nčik

DeA mU/nćak "woodpecker"

( $\mathrm{J} \mathrm{mU} / \mathrm{nDZak}$ "smal1 woodpecker")

YamF manće?k (correction of man $c^{\partial} e^{? q}$ ) "yellowhammer"

(P) ha'lok

(F ha?log

ha'

(D) ha'/aluk

DeA ha ' 1 Uk "raven" (?)

( $\frac{\text { ha.' (?)1Uk }}{\text { woodpecker") }}$ "large

YamF ha'loq "big red woodpecker"
MRF an če.'?qh "yellowhammer

SJ anći.'?q "yellowhammer" YoncJ

One of the larger woodpeckers (1877a:40); feathers black on top, red underneath, used in ceremonial regalia (1877a: 358-360). (The description of the feathers clinches this identification.)

MRF a 10? q "red-headed woodpecker"

(G) al 10?q "red-headed woodpecker"

SJ $\frac{a^{?} l u^{\prime} \text { q }}{\text { pecker" }}$ "large black wooda?lu'qu "large black wooda? a $^{\prime 2}$ pecker" "large black wood-

YoncJ Ga'?10?q "big redheaded woodpecker" Ga'"1o?k "big red-headed woodpecker"

Scalps used in ceremonial regalia (1877a:360).

(P) ma'ntIS

( $\mathrm{F}$ mántiš)
MRF an $\frac{t \mu^{\prime} \cap i_{s}}{\text { sapsucker" "woodpecker or }}$ (G) an thes? "woodpecker or sapsucker"

SJ anti'?š 'sapsucker' ant $\overline{1 / 2 \mathrm{~s}}$ ' sapsucker' anDi'?گ 'sapsucker'

YoncJ Ga'ntIš 'sapsucker' tI'? 'sapsucker'

0. Falconiformes, 0 . Strigiformes:

(26) Turkey buzzard (turkey vulture, Cathartes aura
(P) $\underline{\text { at I'f }} \cdot \mathrm{I}$

(F $\underline{t+f \cdot i \cdot)}$

(P) a'tIf
MRF tifo? 'buzzard' SJ antifu? 'buzzard'

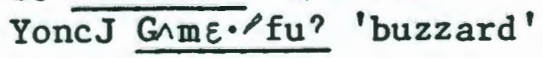


(IInnaeus T)

(F ati/f)

YamF tIf, tif

(27) "Hawk"

(generic), or "big-

gest hawk" (Buteo

sp.) (sp.?)

(28) (Another sp. of Buteo?)

apo'1.1o
(P) apolio

abolio

(F a $\mathrm{po}^{\prime} 1^{7} \mathrm{yo}^{\mathrm{h}}$ )

DeA tpo 1?y I "hawk"

( $\mathrm{J}$ tpo $\bar{j}^{2} \mathrm{yU}$ "chicken hawk")

(P) a'mpsank

(F a mpsank)
Cf. (?) Wishram (French) a-ntixwa 'buzzard'

Eats dead animals (1877a:40). SJ ampu'1?yu • "sma11 chicken

SJ(E) pu'1'yu "hawk, common ordinary, large, sort of bluish"

MRF $\mathrm{psa}^{\mathrm{n}} \mathrm{q}$ "red hawk, chicken hawk" (red-tailed hawk?) MRF(G) am psanqh "chicken hawk"

SJ ampsa'pk "large chicken hawk"

Cf. Wasco-Wishram (French) a-psa'q' 'red-tailed hawk'

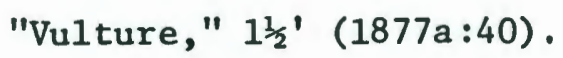

(29) "Grey eagle" (golden eagle, Aquila chrysaetos IInnaeus/?)

(P) ača'nxa/ua'n/uan

-uan/uan 'wings'

"Grey eagle," smaller than ači/n.un (1877a:40)

(30) (Bald eagle, Haliaetus leucocephalus IInnaeus /

(P), ačI'n*un, ałt... (F $\overline{\left.i^{\prime} n \cdot o n\right)}$

DeA हैIn.Un "eagle"

YamF $\varkappa_{u} \cdot n_{n} h$

$\mathrm{cu}_{\mathrm{u}} \cdot \overline{\mathrm{nu}_{\mathrm{n}}}$ "eagle"

(another Yamhil1 word is given for golden eagle)

MRF an či.'nu. 'bald eagle' cyl'no 'bald eagle' (G) ${ }^{\prime} \bar{i} \cdot$ 'nu. 'bald eagle' YoncJ cilnu 'bald eagle' Cf. Wasco-Wishram (French)

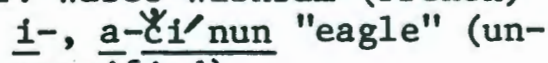
specified)

Eagle, "the biggest bird in Oregon," "boss of birds" $(1877 \mathrm{a}: 40)$; feathers used in ceremonial regalia (1877a: 359).
(Immature bald
(P) a10/polop eagle?)
(F 10?plop)
(P) a10'pol.op
(F $\frac{10^{\prime} \mathrm{plop}}{\text { 'grey spotted') }}$

"An eagle," size of ača'nxa/ua'n/uan, speckled (1877a:40, 63). 
(31) (Osprey,

Pandion halaetus ILinnaeus/?)

(32) (Sparrow hawk, Falco sparverius

Linnaeus)
(D) $\chi_{u}^{\prime \prime} Y$

(P) ali’̌̌Ilič

(F 1i?čali?č)

DeA 1Ica?1Ic "hawk" ( $\frac{1 \mathrm{I} \mathrm{I}^{\prime} \mathrm{AlI} \mathrm{c}^{\prime}}{\text { hawk") }}$ "little
Large fishing bird, white head (1877a:282). Another possibility might be the great blue heron, but another word is given for the latter; see 非(9).

$\mathrm{SJ}(\mathrm{E}) \wedge ? 1 \mathrm{I}$ CัU?11と "1ittle snake-mouse field hawk"

Small hawk, grey and red, "stand long in air" (1877a: 40). (The indicated color, size, and hovering habit point to the sparrow hawk.)

MRF an tpo'po? 'screech owl' SJ antBu'Bu? 'screech ow $1^{\prime}$ Bupu $/$ ?p a tiny ow1 "the size of a matchbox;" "when he hoots early in the morning the people used to say its going to be a fine day" (contrast this statement with the information below) (Jacobs, Santiam slip files). YoncJ tBo.'Bo 'screech owl'
(33) (Screech owl, Otus asio /Linnaeus/)

$$
\begin{aligned}
& \text { DeA } \frac{t p \rho b}{B D \cdot o w l} \text { "owmall } \\
& \text { owl") } \\
& \text { YamF tpo?ph 'screech } \\
& \text { owl }
\end{aligned}
$$

(34) "Owl" (great horned ow1, Bubo virginfanus (Gmelin/)
(P) atukəlu

(F $\left.t \mathrm{u}^{2} \mathrm{ki10^{ \circ }}\right)$

(D) $a^{\prime} t U k 1 U$

DeA tuk1UhU" "owl" (J DU/Gulu. "big owl")

YamF a du'gulhuh
MRF tu' $\mathrm{k}^{\mathrm{u}} \mathrm{ru} \cdot 1$ "horned night ow1"

(G) $\mathrm{tu}^{\prime} \mathrm{ku1} \mathrm{Y}_{\mathrm{hu}}$. "horned night ow $1^{\prime \prime}$

SJ anDu'Gulhu• "large owl"

The Mary's River and Santiam texts indicate that the call of this owl was a sign of bad omen (Jacobs 1945:78, 349).

$1_{\text {Frachtenberg records }} \mathbf{x}$ (trilled, according to him) only in a very few forms. 
(35) "Smal1 ow1, high voiced"

(sp.?)

ㅇ. Passeriformes:

(36) (Steller's jay, Cyanocitta stelleri (Gmelin $/$ )

(37) "Bluejay" (scrub jay, Aphelocoma coerulescens (Bosch/)
(P) amU'tu/us

(F hu'tuš)

MRF an ho' "towos "mountain ow 1 "

MRF sqa'yaq bluejay with "chub" (as opposed to the white-bellied bluejay, tqwa $^{i_{s}}$ (hence, the inference that the Tualatin-Mary's River word refers to the Steller's jay).

A blue bird, "same size as b1uejay" /see 非(37)T (1877b: 51).

MRF tgwa1s "bluejay, white

(G) tqwa'i.s

DeA a'nţqwaIs "jay" YoncF kan tkwai. ?s "bluejay" ( $\mathrm{J}$ 'ntkwais "bluejay")

YamF an thwai.sy

"jaybird"

(38) Raven (common raven, Corvus corax Linnaeus)
(P) $\varepsilon^{\prime} f 1 I$
(F $\left.\underline{\underline{\varepsilon^{\prime} f 11^{\circ}}}\right)$

Or: (P) kuä.k uH.k

YamF íf1i.

(P), ( ) a $a^{\prime m I 1}$

( $F$ a? mo1)

(P), (D), (_) a $\underline{\text { a m } ә 1}$

DeA a./?hmul

( $\mathrm{J} \underline{\mathrm{ha/mU1}}$ )

YamF a.?mu?1

a. mo1?
MRF f f're'he 'raven'

(G) a(n) fa'lahe 'raven'

YoncF figli. 'raven'

Yonc J çafe.'1I "blackbird"

Black, bigger than crow, lives on dead animals (1877a:40).

MRF mo'la 'crow'

(G) am mo? $1 a^{h}$ 'crow'

YoncJ GUmU?1a'?1a? 'crow'

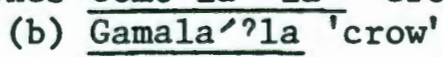
Brachy 
(40) "Wren," F. Troglodytes (sp.?)

(41) (Western meadowlark, Sturnella neglecta Audobon)
(P) a I'f̌̌Ifa

(F čif

MRF tmu'tkwi.z 'meadowlark' Yonc $\overline{\mathrm{J} \text { GimI'tGwi }}$. 1 'meadowlark ${ }^{\top}$

DeA tmU'tkwez "lark"

( $\mathrm{J}$ tmU'tkwAz 'meadowlark')

YamF tmu čkwi·t

Lark, llving on prairies; speckled, green on breast (1877a:40).

$\operatorname{MRF}(G)$ an $c^{y_{a} ? k^{h}}$ 'blackbird'

(42) Blackbird, F. icteridae (sp.?)

(P) ača'kačak

(F čák

(_) $a \mathrm{~J}^{\prime} \mathrm{ka}$ jak

DeA čakčak

( J $\overline{\mathrm{DJ} \wedge^{\prime} \mathrm{DJ} \wedge \mathrm{k}}$

D Ja'DJAk)

(P), ( ) atä/kt

(F a t $\underline{\underline{a} k t i k a)}$

YamF $\frac{t_{a} \cdot{ }^{\prime} \text { kdagah }}{\text { "snowbird" }}$
MRF an 'ta'kalyam, "blackcap, ...lam snowbird" YoncJ Ế kəlala "snowbird"

3-4", grey with black head $(1877 \mathrm{a}: 12)$. "Snowbird" is an older common name, still in local use, for the Oregon junco.

10c-2. Yamhill Names for Which No Corresponding Tualatin Terms Were Found

(44) Golden eagle YamF twäc [see 非(29) 7

(45) Nighthawk YamF am hi.'yuštampqu

(common nighthawk, Chordeiles minor [Forster /)

(46) "Small woodpecker" (sp.?) 
(47) Robin, Turdus YamF a'm pci migratorius

(Linnaeus)

MRF am pčt.h 'robin'

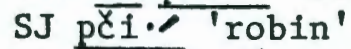

YoncJ G^'mpšI 'robin'

YoncF peI. 'robin'

10c-3. Introduced Birds

(48) Duck, tame

(49) Chicken

Rooster

(50) Pigeon

(P) amIng $\varepsilon^{\prime} a$

$$
\begin{aligned}
& \text { a'mpiuk same word as for } \\
& \text { wild duck / } /(6) 7 \\
& \text {-sutu'pin apparently a con- } \\
& \text { traction of su'l 'good,' } \\
& \text { t-hu'pin 'its-heart' (ex- } \\
& \text { pression used in reference } \\
& \text { to persons, also to mean } \\
& \text { "tame," "domesticated"). }
\end{aligned}
$$

Same word as for ruffed grouse ("pheasant") --\#(18).

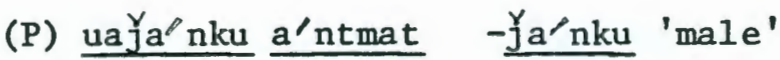

Same word as for wild pigeon - - 非(20).

10d. Fish and Other Aquatic Fauna ${ }^{1}$

10d-1. More or Less Identified

Presumed identity of organism

Tualatin and Yamhill Notes, related terms from terms other languages

Molluscs and Crustaceans:

(1) "C1am"

(P) Ca'mi'1.akue. 'ci.f

(F $\overline{\text { ča } \mathrm{mi} i^{\prime} 1 \cdot a k w i \cdot a}$ ç

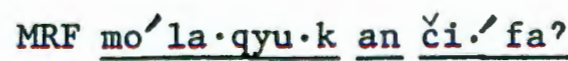
"crab"

'ocean crawfish' (mi'1.ak[MR mo'la.q-] 'ocean;' čtiff 'crawfish') 
(2) Crawfish

(3) Mussels

(fresh water)
(P) () ačl.'f, (F $\underline{\left.\dot{X}_{1} \cdot \bar{f}\right)}$ a....
(D) ačt'f

YamF a $\underline{\underline{j}} \underline{\underline{Y} \cdot \mathrm{f}}$

(P) $\frac{a t u^{\prime} k u i z}{\left.\text { (F } o^{\prime} k w i z\right)}$

YamF tu.'kwiz
MRF $\chi_{1} \cdot \mathrm{fa}^{\prime}$ 'crawfish' SJ anci./faq 'crawfish'

Eaten (1877a:168), A Mary's River myth, in Jacobs (1945: 223), mentions that they were boiled).

\author{
MRF kwi.L 1 'fresh water \\ mussels'

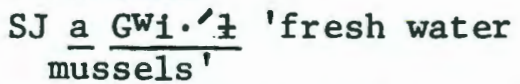

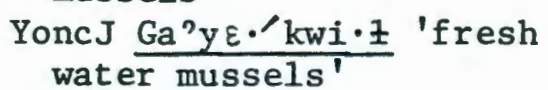

Eaten (1877a:168).

Salmons and Trouts (Family Salmonidae):

(4) (Chinook cus tschawytscha 7Walbaum; probably specifically spring chinook) salmon, Oncorhyn-

MRF tmo'ak "salmon" (G?) an tmu.'ak "salmon" SJ antmu'wag 'chinook salmon'

Caught in June, the fattest salmon (1877b:58); the biggest salmon, $3^{\prime}$ (1877a:205); big salmon, caught in July (1877a:153); dried for winter, bolled for eating (1877a:166). Runs of spring chinook existed aboriginally in the larger Willamette tributaries heading in the Cascades (notably in the North and South Santiam, McKenzie, and Middle Fork tributaries), but were apparently nonexistent or insignificant in the smaller and warmer tributaries such as the Tualatin and Yamhill Rivers (see sec. 8b).

(5) (Steelhead, Salmo gairdneril Richardson)

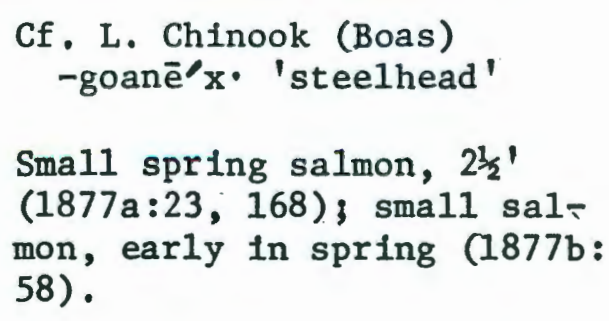
$(1877 a: 23,168)$; small sal= mon, early in spring (1877b: 58).

It is possible that steelhead were established aboriginally in Tualatin area streams. 
(6) Trout (native or cutthroat, Salmo clarkii Richardson)

(P) aba't.ouf $a b a^{\prime} t \cdot o / u f$ aba't.of (F $\overline{\mathrm{pa}^{\prime} \mathrm{t} \cdot \mathrm{O} \cdot \mathrm{f}}$ )

$\mathrm{J} \underline{\mathrm{Ba}^{\prime} \mathrm{Du} \cdot \mathrm{f}}$ YamF $\underline{p^{\prime} \text { tôf }}$
MRF am pa'ttafih 'trout' SJ a $\overline{\mathrm{mBa}}$ 'Dafi 'trout' YoncJ Ba.'DamfI 'trout'

Caught by line (with, e.g., grasshoppers as bait), or trapped in stationary basketwork traps placed at creek mouths $(1877 \mathrm{a}: 73,153)$.

(Salmonidae, specific identification uncertain:)

(7) (P) ( ) $\underline{\text { aka }} \overline{1} \cdot a m$

YamF qa.1am "chinook salmon"
MRF an qa'lam "silverside" or qa) Cf. L. Chinook (Boas) -qE1Ema "fall salmon"

Clackamas (Jacobs) i.g $\partial^{\prime} 1 \mathrm{ma}$ "dog salmon"

"Dog-fish," the longest fish (1877b:58); "dogsalmon," crooked nose, larger than amhu'ya (?) (1877a:168).

The chum salmon (Oncorhyncus keta) is commonly called "dog salmon," in reference to the distorted, crooked jaws acquired by males during spawning season; however, males of other species also acquire this characteristic and are consequently also sometimes called "dog salmon." Since the indicated large size makes it unlikely that this could be the chum, I speculate that this word refers to spawning fall chinook, or perhaps specifically to spawning chinook males.

(8) (D) $a^{\prime} 1 a m \cdot i k$ (F $\frac{a 1 a^{\prime} m i k}{\left.1 a^{\prime} m i q\right)}$

(9) (P), ( ) aua kauan (F wa'qawan)

DeA ka'wan "fish" ( $\mathrm{J} \underline{\mathrm{k} \mathrm{a}^{\prime} \mathrm{wan} \text { ) }}$
Cf. Hale ala'meuk "salmon"

Big salmon, $3^{\prime}$ (1877a:243, 244).

MRF an qa'uwan "chinook salmon"

Cf. L. Chinook (Boas) -'qawEn "silverside salmon"

Clackamas (Jacobs) gawan "dog salmon"

Wasco-Wishram (French) i-; a-qawan (Wasco: "white" or "dog" salmon; Wishram: "degenerated chinook") 
Red-skinned salmon, caught in December (?) (1877a: 168); fall salmon (1877a:23, 1877b:58).

The De Angulo-Jacobs translation as 'fish'

(generic) seems doubtful; Louis apparently knew very few names of fish.

The indication that this salmon was caught

late in the season points more to chum or silver salmon (Oncorhynchus keta, 0. kisutch) than to fall chinook. The Clackamas and Wasco-Wishram translations and notes further suggest $/ \overline{c f}$. (7) above $\bar{T}$ that this word refers specificaliy to spawning fall salmon (or spawning males) of one or more than one species.

It is conceivable (though I have found no direct evidence for or against) that some fallrunning salmon may have migrated above Willamette Falls during high-flow periods in the late fall and winter, thus perhaps being established aboriginally in Tualatin-area streams. Fall-running salmon moreover would have been avallable in coastal tributaries (e.g., Trask River).

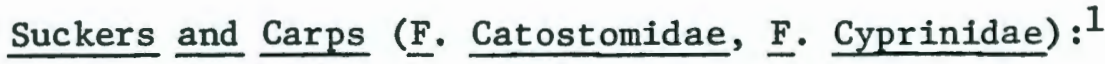

(10) "Sucker,"

"chub"

(a)

(P) aka" "smallest sucker"

(b)

(_) $\frac{a_{k \partial l a} \cdot k t}{\text { sucker" }}$

MRF (G) و́la qta "chub"

$\mathrm{SJ}(\mathrm{E}) \mathrm{k} 1 \mathrm{a} / \mathrm{kDa}$ "sucker"

(c)

$$
\begin{aligned}
& \text { (P) awa'šxua1 "sucker" } \\
& \frac{\text { wa'šxwa1 }}{\text { wa'šxo1) }} \\
& \text { J wa'šxwə1 "chub" }
\end{aligned}
$$

The separate denotations of these three terms are obscure: awa' šxual apparently means any sucker

${ }^{1}$ Larger native species presently found in the Yamhill River include the large-scaled sucker, Catostomus macrochellus Girard, chiselmouth carp, Acrocheilus alutaceus Agassiz and Pickering, Columbia River chub, Mylocheilus lateralis Agassiz and Pickering, and the northern squawfish, Ptychocheilus oregonensis (Richardson) (source: Willamette River Project, Cariton Division, ca. 1972). 
(1877a:168); akə1a'/kt denotes a sucker about $12^{\prime \prime}$ long $(1877 \mathrm{~b}: 58) ;$ in a text on fishing (1877a:153), aka" and aua'šxual are both translated as "sucker," with a marginal note that !'he had two names."

It is stated that aka'/aua'sxual were caught bare-handed and thrown on shore (1877a:153).

(Probably a sucker or carp:)

(11) (D) ačı' hak

(D) $\overline{a y^{\prime} \varepsilon^{\prime} h a k}$

MRF an cá yeky "chub"

"Gudgeon" (1877b:58); "11ttle salmon" (?) (1877a: 244).

Other Aquatic Fauna, Used or Presumably Used for Food:

(12) "Ee1" (Pacific

lamprey, Entosphenus tridentatus IGairdner ()
(P) $a^{\prime}$ nto/u
(F) anto: ha'nto

YamF an to.

Caught, roasted fresh on spits or dired for the winter $(1877 a: 73,166-67)$. The pacific lamprey is anadromous, ascending the Willamette River to spawn in the spring and early summer. Many eels were available at Willamette Falls during the annual migration, where they were found attached by their mouths to the rocks on their way upstream. According to John Hudson (Jacobs 1945:24-25), eels were caught by hand, "at that time when it was getting near to summertime," in creeks (at night by the light of pitch brands, or by day) and at Willamette Falls (it being noted that "all the people" got their eels there); they were roasted fresh on spits, or split lengthwise and smoked over small fires for preservation.
(13) Sturgeon (Acipenser spp.)

$$
\begin{aligned}
& \text { Hale v'mtok 'sturgeon' } \\
& \text { SJ(E) Antu'k 'sturgeon' }
\end{aligned}
$$

\author{
(P) ( ) a a'mtuk
}

Bolled or roasted fresh on spits, dried for the winter (1877a:166).

I have found no indication as to whether the Tualatin caught sturgeons themselves, or whether sturgeons were established upstream from W11lamette Falls in aboriginal times. 
(14) Smelt

(Thalelchthys

pacificus

(RichardsonT)

\section{(_) $4 \mathrm{txi} n \cdot \mathrm{n} \cdot \mathrm{an}$}

10d-2. Identification Uncertain

(15)

(_) ap1U'nta "F1ounder" (1877b:58)

YamF plu'ntah

"mudcat"

(16)

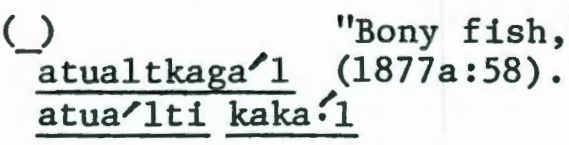
atualtkaga'1 (1877a:58). atua'lti kaka! 1

(17) (_) aya.'mkag Salmon, 1ittle (?) (1877b:58).

10d-3. Yamhill Terms for which No Corresponding

Tualatin Terms Are Given

(18) "Fish"

(generic)

$\operatorname{YamF} \underline{a} \underline{k w a ' y \partial f}$

(19) Silverside

salmon
Probably unavailable to the Tualatin except through trade. 
10e. Reptiles and Amphibians ${ }^{1}$

10e-1. More or Less Identified

Presumed identity of organism

Amphibians:

(1) "Frog" (sma11er)

(2) "Bu11frog" (Rana sp.?)
Tualatin and Yamhill terms

(P) (_) atkua'kua

(F tqwa $\cdot \mathrm{kwa} \cdot$ )

YamF $\frac{t k w a \cdot /() k_{\text {ka }} \mathrm{h}}{)^{\prime \prime}}$

"( ) 111eg1ble

(P) (_) ało'klak

(F $\underline{\text { slo } k 1 \text { ik) }}$

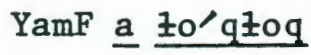

Notes, related terms from other languages

MRF tkwa'kwa "small frog" (G?) tqwaqwa "small frog" SJ ant q'wa'q'wa? "frog" ant $G^{W a}$ G

One of the native species of Rana?

Reptiles:

(3) "Turtle"

(P) $\frac{a_{t a^{\prime} g \partial t}}{\left.t a^{\prime} k i z\right)}$

(_) $\mathrm{ata}^{\prime} \mathrm{g}^{\mathrm{a} z}$

(P) (D) (_) ačaklfi’f-ak
Hale ata'kutx1 "tortoise" MRF ta'qa?1 "turtle" $\mathrm{SJ}(\mathrm{E}) \mathrm{\textrm {Da } \prime \mathrm { Ga } 1}$ ? "mud turtle" YoncJ GumIDa*Gu? "mudturtle"

MRF ̌a'kala a me.'fa? "larger 1izard"

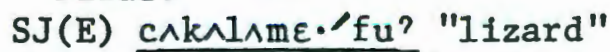

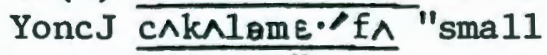
grey lizard"

In dead trees, runs fast (1877a:205).

(5) Snake (generic); or garter snake (Thamnophis spp.)
(P) (D) $a \operatorname{atm} \varepsilon^{\prime} i g^{u}$

(F $t^{\left.h_{m e} \cdot \frac{g}{g w 1}\right)}$

(P) atme'igui atmélgu
Hale vtume'ikwa "snake"

"Any kind of snake is atm $\varepsilon^{\prime} i \mathrm{~g}^{\mathrm{u}}$ (generic) but in fact a little black IoneT with white (1954).

$1_{\text {Binomials and order of presentation generally follow Stebbins }}$

Gatschet (1877a:343) notes that the Tualatin did not eat snakes or 1izards. Eustace Howard (Jacobs 1928-36, \$84:3) noted that frogs, 11zards, and snakes were "not used" by the Santiam. 
'gamF a $\frac{\mathrm{a} m e \cdot / \mathrm{k}}{\mathrm{u}}$ strips, not poisonous--garter snake" (1877a:209).
(6) ("Two-headed" snake--rubber boa, Charina bottae /Blainvilie//)
(7) "Copperhead snake" (probably garter snake, Thamnophis sp.; possib1y ringneck snake, Diadophis amabilis Baird and Girard)
I include a note on this interesting creature, a1though the Tualatin and Yamhill data do not mention 1t. This is apparently the "blind-two-headed-snake" mentioned in Jacobs' and Frachtenberg's Santiam and Mary's River texts. Jacobs gives SJ a?la'ufu? 'blind-two-headed-snake,' which John Hudson indicates was blind, with two heads at its opposite ends. Frachtenberg's informant William Hartless noted that the "snake which has two heads" was dark brown to yellow. Both informants noted that seeing the blind-two-headed-snake was a sign of very bad omen. Hudson added that individuals would "try their heart" by placing the blind-two-headed-snake on an arm: if the snake wrapped around one's arm it was a good sign; if it just dropped off, it was a sign of impending death. The indicated color, constricting habit, and "two-headedness" point to the rubber boa, whose blunt, rounded tail is suggestive of a second head (cf. description of the rubber boa in Stebbins/1954:352-353/: "tail short and blunt, usually almost as blunt as head, giving rise to common name 'two-headed snake'," |alsot. "the blunt tail may be moved in a fashion suggesting head movements while the head is protected by coils of the body," "striking movements of the tail are said to occur").

\section{( ) ala'kuayak}

YamF $\frac{a}{\text { "1 }} \frac{1 \mathrm{a} \cdot \text { ? }_{\mathrm{kwa}} \mathrm{r} \text { " }}{\mathrm{rd}}$

"Copperhead snake" (1877b:60).

"Copperhead" here could refer to the reddish coloration on the mouths of certain garter snakes or, possibly, to the neck and mouth of the ringneck snake. In one of Frachtenberg's (1913-14a Vo1. 1: 54-55) Mary's River myths, the snake named an ca/c cqala'q, given as 'gartersnake' by Frachtenberg (but as 'copperhead snake' in Jacobs' /1945: 221 / reworked version of Frachtenberg's text) burns his mouth carrying fire, thus explaining, according to Frachtenberg's marginal note, why the mouth of gartersnake has a red strip. 
(8) (Probably

racer, Coluber constrictor Linnaeus)

(9) (Gopher or bul1 snake, Pituophis catenifer Blainville
(P) atkuI'/utank [atku'I... ?]
(F tku'yutak)

(P) ma/nčum
Grey snake, "runs fast," bites, not poisonous, 2-3' (1877a:209).

\author{
MRF (G) an čom? 'bullsnake' \\ ("blows," \\ people) \\ YoncJ Ga'nču.mU? 'bu11snake'
}

(10) Rattlesnake (western rattlesnake, Crotalus viridus Rafinesque)

"Puff adder," on Willamette; black, white spots (1877a:209).

The coloration of the gopher snake is light brown to whitish, with a row of large brown, black, or reddish splotches running the length of the body (the informant sees lighter spots on a darker background). The name "puff adder" suggests the loud hissing and spreading of the head noted for this species (cf. Stebbins 1954:392-394).

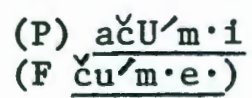

YamF a $\underline{\chi_{u} \cdot / m i \cdot h}$
YoncJ swu.'mIk 'rattlesnake' The Yoncalla and TualatinYamhill words resemble each other more than either resembles the Santiam-Mary's River word for rattlesnake (SJ antk $\bullet^{\circ}$ ). (Interestingly, the latter resembles the Yoncalla word for 'snake' or 'gartersnake,' given by Jacobs as Ga'nkE.', by Frachtenberg as kan $\mathrm{k}^{\mathrm{h}} \mathrm{yah}^{\mathrm{h}}$.

Rattlesnakes are native at least to parts of the Willamette Valley, and are found now in some limited areas of the central and southern valley. I have found no indication as to whether or not rattlesnakes were native to Tualatin territory. Jim Riggs (1975, p.c.) informs me that he has heard of rattlesnakes being found, relatively recently, as close to Tualatin country as the hills near Amity, just south of McMinnville. It seems possible that rattlers occurred in areas of favorable habitat (e.g., open south-facing slopes) within Tualatin territory.

$1_{\text {Gatschet always marks stress on diphthongs following the final }}$ component vowel. Frachtenberg's correction suggests ...u' I... here, but ...wI!... is an equally possible reading. 
The fact that rattlesnake is cited as a spiritpower (1877a:63) suggests that rattlesnakes were within the sphere of Tualatin experience.

There are mentions of poisoning persons with "poison of snake" and of putting poison on arrow tips (type of poison not indicated) (1877a:345-346). No details are given here, but Frachtenberg's (1914a) Mary's River notes do record the use of rattlesnake poison, applied to tips of war arrows. Jacobs (1928-36, 非:60) was told by Eustace Howard that the Santiam never ate rattlesnakes, but that "some tribe to the south" did eat parts of rattlesnakes for power reasons, additionally mixing the mashed bony rattles with tobacco for the same reason.

An early settler (Applegate 1930:214-215) notes an interesting case of "snake charming" for the Yoncalla; as a boy, he observed a Yoncalla "doctor" chant to a rattlesnake until it became completely docile, whereupon it was handled with impunity.

\section{0e-2. Identification Uncertain}

(11) (D) apU'nkəlak ap $\mathrm{U}^{\prime} \mathrm{niklaku}$

(_) abU'nxlak
"Lizard," "turtle" (?) ("1izard" is corrected to "turtle" here, with ačaklfi'f-ak being offered as the true word for ' 1 izard') (1877a:388); "red mole? ... (in water, 4 legs with 5 fingers each; once made fingers to / for? mankind, whence its name)" $(1877 \mathrm{~b}: 60)$. (The latter suggests that the name is analyzable in terms of -pun- 'to make, do,' and $-1 \mathrm{a}-\mathrm{k}^{\mathrm{u}}$ 'hand'.) This interesting note possibly points to a salamander or newt (mole salamander?); note the rather human-like flve-digited rear mani characteristic of these animals (although the front mani have only four digits; note, however, that the mani of lizards and turtles seem distinctly unhuman).

10e-3. Yamhi11 Terms for Which No Corresponding Tualatin Terms Are Given

(12) "Waterdog"

(rough-skinned

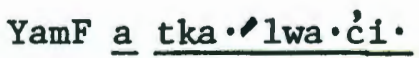

newt, Taricha granu-

losa skilton?) 
10f. Insects, Parasites, and Other Arthropoda $^{1}$

10f-1. More or Less Identified

Presumed identity Tualatin and Yamhill Notes, related terms from of organism terms other languages

Class Chilopoda:

(1) Centipede
(P) atmo'iš
(F tmoi's)
(D) atmo'nš

Class Arachnida (also see "Parasites"):
(2) Spider
(P) ačI'nšəxal [...gal ]

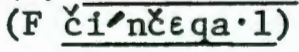
(D?) a Inšəka' 1

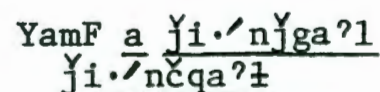

Class Insecta (also see "Parasites"):
(3) "Caterpillar"
(P) $a I^{\prime} I^{\prime} t$
(F $\underline{\left.\underline{\varepsilon \varepsilon^{\prime} y i t}\right)}$
$\mathrm{YamF} \underline{\mathrm{a}} \underline{\mathrm{Y} e \cdot t}$
MRF an $\frac{\mathrm{cya}^{\prime} \mathrm{yIt}^{\mathrm{h}}}{\text { "small cater- }}$ pillar"

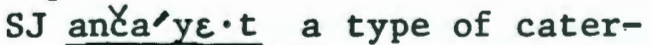

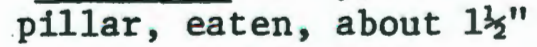 long, striped, not very hairy, eating the leaves of ash trees; not found in quantity every year, but when they come they make the ash trees look bare (Jacobs 1928-36, 非 47:28, $1945: 27)$.
YoncJ Ganša'yID caterpillar
that eats only ash leaves.
Jacobs provides details on the gathering and pre- paration of these caterpillars, from John Hudson and

${ }^{1}$ Since I am completely unacquainted with the intricacies of entomological classification, I do not attempt to use binomials. 
his Yoncalla informant: when the caterpillars were fat, holes were dug near ash trees, into which the caterpillars fell (?); for eating, the caterpillars were boiled or put into baskets and pit-oven

roasted like camas; after cooking, the "fur" rubbed off, leaving just hard white meat, which was very good (Jacobs 1928-36, 非5:n.p., 1945:27). I found no information to indicate whether or not the Tualatin made similar use of this caterpillar.

The early settler Minto (1900:306) mentions seeing a Santiam gathering "tent caterpillars" from ash trees for eating.

(4) Maggot

(P) ap1I' ’̌ak

(F pli/cak)

YamF am p1i.caq
MRF am p11./c?yakky 'maggot' (G?) am p11/cycky 'maggot'

Used as fishing bait (1877a: 73). Same word for "worm."

(Grasshoppers and Crickets:)

(5) Grasshopper

(P) atkui'tunk [atku'1...]? 1

MRF an tqo.yak 'grasshopper'

(F tkwi'tonk)

(D) atku'tunk

(G?) tku·yak 'grasshopper' SJ antGu./?yak 'grasshopper' YoncJ ku.' y^?k 'grasshopper'

YamF a tko'huk

Gatschet nowhere mentions the eating of grasshoppers, though this practice is mentioned for other Kalapuyans. Cf. Jacobs (1928-36, 非5:n.p. for the Yoncalla; 1945:26 for the Santiam), Kruse (1954:1, Yonca11a), Douglas (1904-05, Pt. 3:78-79, general Willamette Valley). One of the reasons for burning the prairies was to procure grasshoppers (Jacobs 1945:26, Douglas 1904-05, Pt. 3:78-79).

(6) Grasshopper, largest type

(P) atxe'sxes

[atg...sq....]

(F tqe'sqas)

(D?) atke' skkE s

(7) Cricket

(P) aptu $\cdot p t u$

(F ptu $\left./ \mathrm{ptu}^{\circ}\right)$

${ }^{1}$ See footnote on page 128. 
(F1ies:)

(8) "F1y"

(P) (A) atkan)

Hale atikaa'ne "fly"

MRF an tqa'naq "fly, house$f 1 y^{\prime \prime}$

(G?) tka'naq "fly, housefly"

YoncJ GUmItko.'nU?k "gnat"

G mItko.'no?q "mosquito"

Small fly

(P) uati'nj ${ }^{\prime} i_{k}$ atka'n

Large $\mathrm{fly}$

(P) uato'f atka'n

"Meat fly"

(P) amhU'kt atka'n

(F amhu.k ...)

amhu'k 'meat'

(D) $a m h U^{\prime} k$ tu/tkan

tu- 3rd person singular possessive.

(9) Gnat

(P) atkui'n:ik

(F t kwi./nik)

(10) Mosquito

(P) atmu/Jukkěuk

(F tmu. c c

Hale tumu'tçuktçuk 'mosquito'

(0. Lepidoptera:)

(11) "Day

butterfly"

(P), (D) aua'nxa/ua'nsxa

[...qa...qa ]

( $F$ wa/nqawanqa)

YamF a wa/nkawank

"butterfly"

(12) "Day

(P) ata'lala

butterfly, largest

(F $\left.t a^{\prime} 1 \mathrm{ala}\right)$

(13) "Moth"

(P) atmU'fmap

(14) "Moth," another kind

(P) ato' kala

(F to./kala)

(D?) to/lukala 
(15) "Sphinx" (moth)

(0. Hymenoptera:)
(P) atkui'nkamz

(F tqwi./nqamz)
"Night butterfly," big head at one end (1877a:33).
(16) Ant

Large ant

Smallest ant

Flying ant

Red "pissant"

Black ant

(17) Bumblebee

(18) Hornet

(19) Wasp

(20) Yellowjacket
(P) $\operatorname{atmI/tImus}$

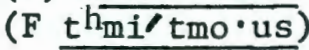
YamF a ti.'tmo.us

(P) uapa'1 atm...

P1.: (P) uanto'f atm...

(P) uat I'nJy atm...

(P) uatI'p atm...

(F wa'ti.p $\ldots$ )

P1.: (P) uAnt I/b atm... (F wa'ntip...)
MRF an tmo.iy 'ant' SJ Ant? ?mI./s 'ant' YoncJ GA'ntmi.wI?č 'ant' 
-an prefix suggests that this is a Kalapuyan loan).

Jacobs notes, for the Santiam, that yellowjacket larvae were eaten: in midsummer, when a nest was found, a fire might be built on top of it to kill or drive out the yellowjackets; the toasted white larvae were then taken out and eaten (Jacobs 1928-36, \#⿰56:30).

Lyman (1900b:325)also mentions the eating of yellowjacket larvae by Kalapuyans, stating that the "combs," with their "honey" and larvae, were considered good eating; the nests were dug out of the ground after the yellowjackets were first "well smoked." I suspect that David Douglas' (1904-05, Pt. 3:78-79) observation that Willamette Valley natives burned off the prairies every year in order to, among other things, procure "wild honey," is a reference to the above-noted method of procuring yellowjacket larvae, since honey bees are not native.

Parasites:

(21) Bedbug

(P) $a m h I / m t$

(F hi $\underline{\text { i?mt) }}$

(22) Flea

(P) a'ntuak

(F twakh)

MRF an twa:q 'flea'

YamF an twa $k$

(23) Greyback

(P) atu'to1I

louse

(F t $\underline{\left.u^{\prime} t 1 i^{\prime}\right)}$

(24) Head louse

(P), () ma'ntiu
(F mo?ntyu/)

YamF ma/ndi.ya di. 'ya 'louse'

(25) "Leech"

(26) Mosquito

See \#(10)

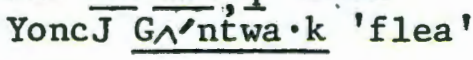

MRF an tygh 'head louse'

(G) to1. 'louse'

SJ -Du't head louse'

Yonc $\overline{\mathrm{J} G \wedge} \mathrm{nDi} \cdot w \mathrm{I}$ 'head louse' 
(27) Nits, on head

(P) malmpəla/nč

(F ma/mplinc)

SJ $-\underline{p} 1 \varepsilon / n c$ Intts"

(28) Tick, on

sheep

(P) a $1 \mathrm{a} / \mathrm{mUnc}$

(F $1 \overline{\left.a^{\prime} \operatorname{mun} \chi\right)}$

10f-2. Identification Uncertain

(29) (P) amhi'uyik "Stink bug," red and green (1877a:34). The name Is (F hi.?yuyikh probably a reference to odor; cf. amhi'uyik $/ \mathrm{sec}$. $10 \mathrm{a}-1$, 非(29)T, name of an aromatic herb.

(30) (P) anto//utUntiu "Ateuchus" (?) (1877a:34). The name seems to (F a $\overline{\text { "nto. tintya) }}$ mean "eel's lice" (anto/u 'lamprey eel, ' tuntiu 'its-lice').

(31) (P) atpU'tuak Little, red, size of nits, in beds, dogs, old houses, (F tpu'twaq etc. $(1877 a ; 34)$,

(32) (P) awu'yakmei "F1re-bug" (1877a:34). (F wu'yakmi.)

10f-3. Yamhill Terms for Which No Corresponding Tualatin Term Are Given

(33) Horse fly $\underset{\text { Yams }}{\operatorname{ans}}$

10f-4. Introduced Insects

(34) Honey bee

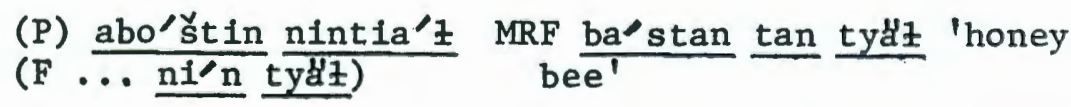

'The Americans' yellowjacket' (bo/štin 'American' /JargonT; nintyaz 'thetr-yellowjacket' '). 
10g. Miscellaneous or Unidentiflable Fauna
(1) "Worm"
(P) aplif ${ }^{\prime} a_{k}$
Same word for 'maggot'
(2) "Rain worm"
(D) ackkue'fank
Used as fishing bait (1877a: 280).
(3) (P), (D) ala't
SJ ala.'la 'poison power' (e.g., sent by malevolent shamans).
A kind of disease object ("worm") that settles in the body, causing disease; removed by shamans $(1877 a: 65-67,290)$.

(4) (D) th' ata ksis

An animal making a noise, smaller than a mouse, with horns, "horned frog?" (1877a:289) (horned toads apparently not being native to the area, the best possibility I have heard suggested as to the possible identity of this creature is that it is one of the larger, more spectacularly antennaed species of beetles).

(Yamhill Term, No Corresponding Tualatin Term:)
(5) Snail
YamF an tpe $\mathrm{u}_{\mathrm{t}}$ an tpeut
MRF an tpo ${ }^{i_{t}}$ 'snail, slug' (G?) tpo.i?th 'snail, slug' MRF an $\mathrm{ce}^{\cdot / \mathrm{yaq}}$ an tpo.1?th snail with shell on

10h. Supernatural Beings $^{1}$

(1) (P) a ju'sčsa Wolf-like, without fur or flesh ("nothing but skin

II include these because I suspect that such beings were just as much a part of the Tualatin "real world" as bears, elk, oak trees, etc. Tualatin informants nowhere indicate any special category of being applying more uniquely to such beings than to other beings which we could consider fully "natural" (cf. sec. 9, where amhu/lukw and atu'nkai, below, are listed, along with crawfishes, salmon, otters, etc., as being among the "things living in the water"). Most of the beings mentioned below were indeed associated with "power" (yu/zme1), but they were not necessarily associated with any superior degree of power as compared to that 
(D) $a 3 U^{\prime} s c a s a$

(2) (P) $a m h u / 1 \partial k^{u}$

(F am hu*1ik)

(D) $a m h U^{\prime} 1 u k^{u}$

(Emmy) amhU'1'k amhU $\overline{1 k}$ amhU'luk

(F am hu०/ luk) and bones"), has a long tail, makes whistling nolses, pounces like a mountain lion, pursues and devours people (1877a:129, 201, 354). "Not fabum lous, in existence. Dave saw IitT below CadiH/mé 1 /the Gaston petroglyphs T--near Gaston" (1877a:354).

This being is mentioned specifically in connection with wolves and Yoncalla Indians. Dave said it was "the oldest wolf" (wa-yu'hiu a/mlint pku-pU/n-3a azu'scosa, 'the-old Tancient? T wolf didmake-self /changed intoT the 3u'scəsa') (1877a:354). Yoncalla Indians transformed themselves into the 3u'scəsa, as well as into grizzlies and wolves, and came north to devour Tualatins (1877a:201-202). Dave adds that the $3 u^{\prime}$ scosa was finally killed by the Clackamas (1877a:354).

$$
\begin{aligned}
& \text { MRF am mo'lugwa 'whale,' } \\
& \text { 'catt } \frac{\text { ' (!), "fabled bad }}{\text { animal living in water" }} \\
& \text { SJ(E) amu.'luGwa (supernatu- } \\
& \text { ral) "whale" living in } \\
& \text { Willamette River (see below) } \\
& \text { YoncF mu.'lyukwah 'whale' }
\end{aligned}
$$

Jacobs and Frachtenberg both suggest that the Central-Yoncalla word is related to Chinookan mu.lak, mo.lak 'elk' (the given Tualatin form however seems less to resemble the Chinookan word). The Tualatin have a different word for 'whale' / see sec. 10b-1, \#(16)T, but the "fabled bad anima 1 "-supernatural "whale" is surely identical to the Tualatins' hu'lukw.

This being was believed to inhabit an inhospitable 1ittle mountain lake west of Forest Grove (probably the former Devil's Lake, about four miles north of South Saddle Mountain). A story recorded in three versions by Gatschet (Jacobs' renderings, reworked with Louis, appear in Jacobs /1945:156-1607 recounts how it long ago seized and thereafter kept two children (it is elsewhere noted that the footprints of the hu'luk ${ }^{\mathrm{W}}$ where it seized the children can still be seen near Gaston); the children became transformed into something "different" or "strange," spotted, with one body, two heads and necks, and four arms. The hu'lukw 1 tself is rather amorphously described: it was "very large," spotted, four-legged,

conferred by other beings (such as, e.g., thunder, eagle, grizzly, which conferred some of the strongest powers). 
had a large spotted horn or horns, its legs were "tied-around" (?) "1ike those of a porcupine" (its legs resembled those of a porcupine?), it was accompanied by spotted dogs (1877a:72, 85-86, 8991). The combined Tualatin, Mary's River, and Santiam references to this being suggest the following characteristics: (i) It characteristically makes water rise--in the Gatschet stories, the water rises when the hu/luk ${ }^{W}$ takes the children away; in a Santiam story given by Eustace Howard (Jacobs 1928-36, \#76:43-141), the amu./1uGWa, who lives in the Willamette River in this version, makes water rise on different occasions towards a boy on the bank, finally drawing him down and keeping him; also, in Dave's creation myth (1877a:244), the hu/lukw is identifled as a "sea monster raising water"). (ii) It transforms things that come under its power--cf. the children in Gatschet's story; the Gatschet notes $(1877 a: 91)$ also state that the lake where the hu'luk ${ }^{\mathrm{w}}$ lived drew things down (e.g., elk, deer, grizzlies), and that "when a grizzly bear is old, he goes there /to that lakef \& turns into something in that lake;" in the Howard story, the boy who was kept with the mu. $1 \mathrm{uGW}_{\mathrm{a}}$ became somehow changed, though the story begins to fade out at this point with Howard being unable to recall the rest very well. (iii) It confers power, apparently being associated with wealth--although there is no reference to a hu'lukw power in the Gatschet MSS, according to Jacobs.(1945:156), "/LouisT Kenoyer said that the $/ \overline{h u} / 1 \mathrm{k}^{W /}$. . gave people a sort of briefly possessed wealth spirit power;" Frachtenberg's informant William Hartless (Jacobs 1945:345) indicated that the molluqwa was one of the "things in the water" which were sought for power; additionally, Eustace Howard indicated, though he was not remembering things very well at this point, that the boy in his story later on became wealthy.

(3) (P) atU/nkh/1 (F to

(P), (D) atU'nkai (F a tivai)
A "fabulous" "sea bear" (Frachtenberg has "spotted dog living in water"), one of the beings conferring power (1877a:63); "a spirlt or bad genius, living in dark deep water; looks almost like a seal, or sea otter," "in river, lakes, deep water" (1877a:88). In the passage quoted above, to the effect that when a grizzly becomes old he goes to the hu'lukw 's lake and "turns into something" there, there is a rather ambiguous addition which seems to indicate that such a grizzly might be transformed into an atu'nkai (1877a:91). 
(4) (P) $_{(\mathrm{acxa} / \mathrm{u}} \frac{\left.\mathrm{cx} \mathrm{a}^{\prime} \mathrm{u} \cdot\right)}{(\mathrm{x})}$
SJ asa'uq'sauqW 'hollerers' (hollering beings heard at night in the mountains; they devour people)

By the description, this being seems similar to the 3u'scasa: ". . In the Cascade m/tnsT-follows tracks of Indians, eats them up, Iillegible--not? afraid of water \& fire; no hair on, or flesh, no= thing but skin \& bones," "size like big dog or calf" (1877a:87-88). Gatschet has a text (1877a:143-146, in Jacobs $1945: 182-183$ ) describing how a cxa'u was killed by a young man at Panther's Den (one of the power-quest places at Grand Ronde), after it had previously killed three other youths there.

(5) (P) aski'yup (F a sqe.yu'p)

(Emmy) ski'yup (F sqi."yup)

A female being, travels through the air, wears a short cedar bark dress $(1877 a: 85,87,106)$; confers power (1877a:106-107); she always dances when appearing to people (i.e., to those who recelve her power?), on her head (legs up), back, sides, walks. on her back, etc. (1877a:362). According to a text dictated by Emmy (1877a:87), few "knew" ski cyup (had her as their power); her appearance could be fatal: "whoever she would get to in the country, just blood would come out of his mouth. (When) a woman went for water, she would drop dead, if (because) ski 'yup appeared to her" (Jacobs' translation; Jacobs [1945:1797).

Gatschet has some notes on winter-dance performances connected with this being. E,g.: "1'ha wa/hi, wa1, he wa'thi, wa'ht, waho. . sung while rattling the acu' xtaxa /hollow rattiet. As the aški-yup is a being which can walk on $\bar{h}$ is hher back, head, feet or sides, they express by singing how he IsheT walks, travels, and accompany this by the gesture of head shaking: a'hi, nua'h1, wa/h1. etc." (1877a:401). 


\section{CHAPTER IV}

\section{OTHER CONTRIBUTIONS: TUALATIN WINTER-VILIAGE GROUPS}

\section{HOUSES AND SETTLEMENT PATTERN}

The Tualatin spent the colder months of winter at permanent wintervillage locations, in multi-family winter houses. Little detailed data are available concerning Tualatin houses and settlement pattern. Gatschet gives the following different words for houses or dwellings:

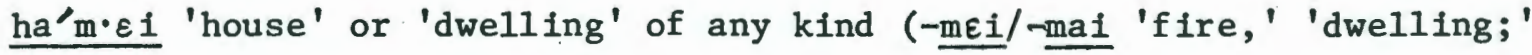
-ma. in Santiam-Mary's River); apyo/uše./1d 'winter house' (-pyo/uš'winter,' -e.1(d) 'house,' perhaps specifically permanent or winter house; -d suffix?; cf. Mary's River pya/usI-la 'winter-village,' Yon-

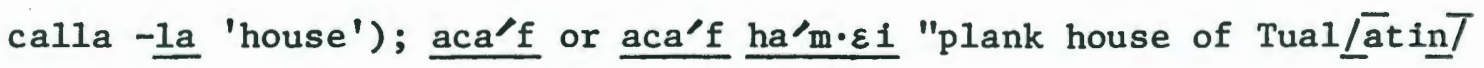
before coming to reserve;" am $\varepsilon^{\prime}$ kwinfun (from $\underline{m \varepsilon^{\prime} k^{w}}$ 'summer,' referring to temporary summer shelter); ata'tal '(temporary) hut' (referring to temporary grass, brush, rush, etc. dwellings). A translation of apyo/use.'1d at one point as "mud house," and the giving of ha/nkelop ('earth') apyo/uše/1d (1.e., 'earth' or 'dirt winter house') as a type of dwelling (1877b:33, n.p.) suggest that the Tualatin had the earthbanked, bark-roofed type of winter house noted for central Kalapuyans (alluded to for the Santiam in Jacobs II945:39T; some details on one variety are given in Frachtenberg's /1914a:n.P.T Mary's River notes, published in Mackey $[$ 1974:42T). Plank houses, of course, were notably characteristic of neighboring Chinookans. 
There are no data as to the comparative importance of the two basic winter-house types mentioned above; it does seem plausible to suppose that where both were represented, only wealthy families could have had plank houses. A note (1877a:13) that ash bark (spread in June to dry for use during the following year) and cedar bark were used in house construction, could conceivably refer either to the bark and earth centraltype house, or, possibly (or additionally), to the bark-covered, plankroofed houses noted for lower Willamette-Vancouver vicinity Chinookans (ash and cedar bark are also noted to have been used to plug airholes in houses during cold weather). An early apparent reference to plank houses in use among northern Kalapuyans occurs in Rees' (1880:22) recounting of information passed on to him by a member of the 1812 Donald McKenzie expedition. According to Rees, Champoeg village (located somewhere in the vicinity of the state park of the same name /see Hussey 1967:17-18 "cedar houses" (that is, cedar-plank houses?).

The Gatschet notes $(1877 \mathrm{a}: 13,192,236 ; 1877 \mathrm{~b}: 33)$ include references to the following aspects of Tualatin houses and settlement pattern. Winter houses were 40 to 50 feet long, with two to four or five famllies in one house; each individual family was partitioned off; there were two or three three-feet-high doors per house; there was a central fire pit and smokehole; planks, with excavated leg-room, were provided for sitting; there were storage scaffolds; tule mats were used as mattresses; beds were raised, being about three feet high (there is also one interesting note to the effect that "bedsteads" were made of planks, "painted with fancy ornaments," inside of which nets were stretched as mattresses). Houses might be joined together in long house rows (e.g., 100 feet 1ong). 
Also, a Tualatin village might have a large "council house" (a'kanaiku $\underline{t U^{\prime} m \cdot a i}$ 'the council its-house') where, for example, war councils involving the village men were held.

\section{WINTER-VILLAGE GROUPS}

The following were all presumably winter-settlement sites. In one of Gatschet's texts (1877a:148-150; in Jacobs $145: 186-187$ ), a number of them 非(1), (3), (4), (5), (6), (8), (9), (10), (12), (13), (14), (16),

(17) belowT are specifically mentioned as sites where winter houses were

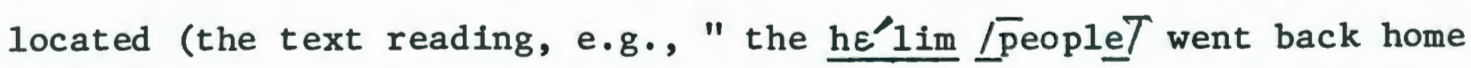
when it was wintertime to their winter houses, their place was there at he'lim," etc.). I cite any mentions of chiefs or individuals said to be from a particular village group, to provide additional evidence that a group name rather than merely a place name is at issue (the information about Tualatin local groups in Hodge /1907, 1910T, compiled by Livingston Farrand from the same data of Gatschet's cited here, contains some confur sion on this point, Farrand identifying at least two, and perhaps more, place names as group names).

I abbreviate the more frequently cited references, as follows:

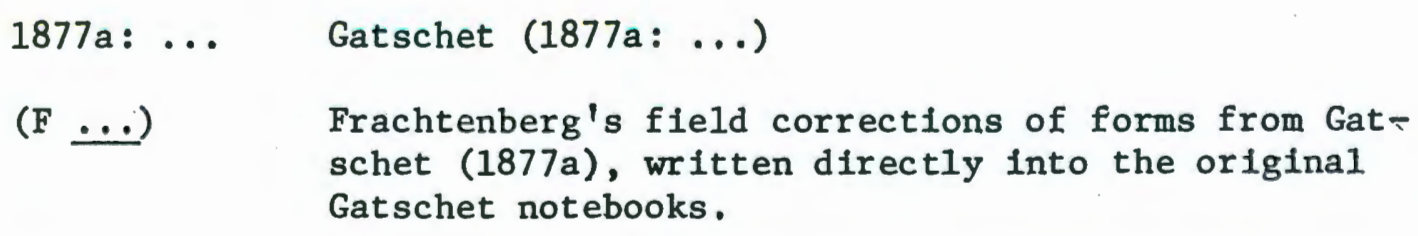
schet (1877a), written directly into the original Gatschet notebooks.

Fracht Frachtenberg (ca. 1915:55-56)-Frachtenberg's unpub1ished typescript of Gatschet's text on wintervillage groups.

Jacobs Jacobs (1945:186-187)-Jacobs' revised version of Gatschet's winter-village text (Jacobs did not have the benefit of Louis Kenoyer's help on this text, so that cited forms represent, not re-elicitations, but 


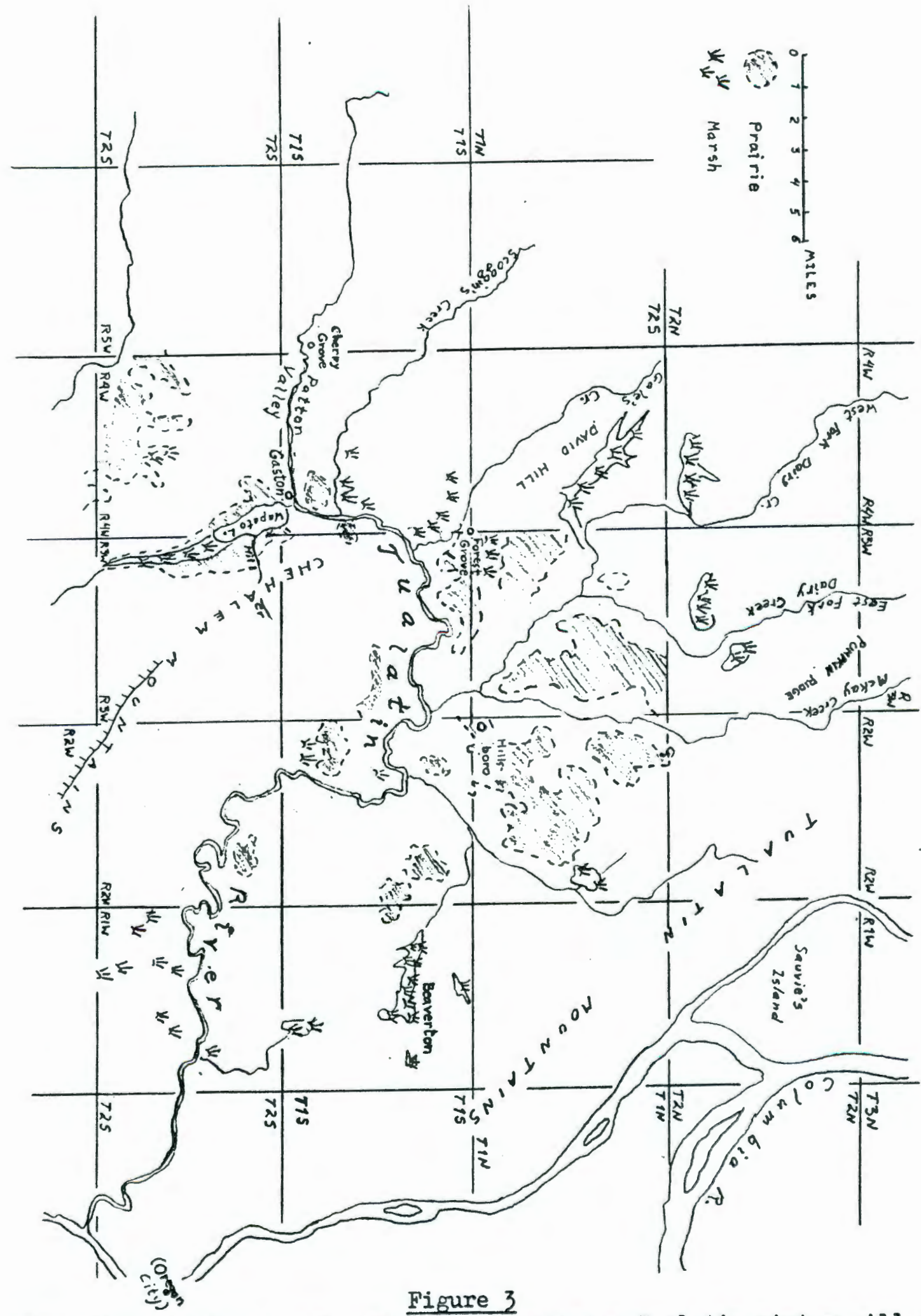

Geographical features referred to in localizing Tualatin winter villages (for some features not shown, see figure 1) 
merely Jacobs' own phonetic reinterpretation of Frachtenberg's typescript in conjunction with Gatschet's origina1).

Hodge I

Hodge (1907:108, plus alphabetically organized references to each named village)-- Farrand's compilation of Gatschet's data.

12a. More or Less Definitely Identified

(1) ča-čim.ahi'yuk. -hi'yuk an aromatic herb growing in marshy places Isee sec. 10a-1, 非(30)/; names .

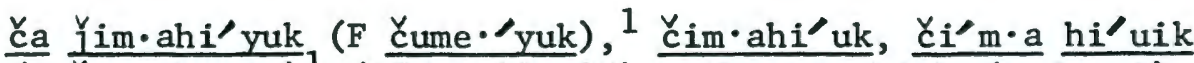

(F čema/hawig) 1 (1877a:30, 95). Chachimahiuk (Hodge I).

Probably located somewhere south of Beaverton, near Tualatin River. There is an element of confusion in the location, Gatschet originally giving it as "near Oregon City, on this side of Willamette River," but subsequent1y crossing out "Oregon City" and writing "Wappato Isic/ 1ake" (1877a:95). However, the location is elsewhere given as "between Oregon City and Chehalem" (i.e., west or southwest of Oregon City, "Chehalem" presumably referring to the vicinity of Chehalem Valley and Mountain) (1877a:30). Furthermore, it is stated (1877a:95) that the chief of this village was "probably same as Ioff/ ča $\mathrm{k \varepsilon}$ 'ipi 俳 $(52 \bar{I}$." In view of the latter statement, it seems 1ikely that the two mentioned villages were located relatively close to each other. If I am correct in locating $\underline{X a}_{\mathrm{k}} \underline{\mathrm{k} \varepsilon^{\prime} \mathrm{ip} i}$ at or near Beaverton, the case is thus strengthened for locating ča-čim.ahi'yuk in the general area suggested here. "B1ind Dave" was from this group (1877a:30).

${ }^{1}$ It seems $1 i k e 1 y$ that Louis did not recognize this name. 
(2) ̌a or marshy ground, frequently overflowed').

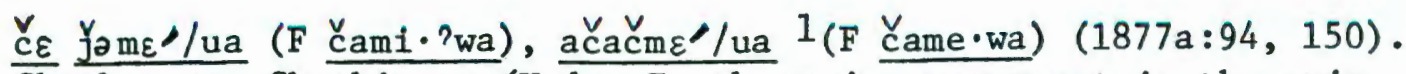
Chachemewa, Chachimewa (Hodge I; there is no support in the original Gatschet MS for Farrand's implication that two groups bore this name). ča čme/wa (Fracht). čačme'wa (Jacobs).

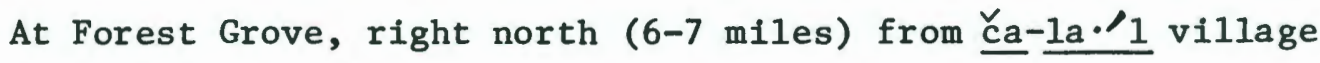
I非(7)T. ku'iyape / i , a tu'ktalak ('great warrior') was from there (he was not a chief though) (1877a:94).

(3) ča-čókwiz. Said to be named for a kind of shell.

ča čolkuiz (F ča'kuł), ča čo'kuaz, ačačo'kuiz (1877a:92, 97, 150).

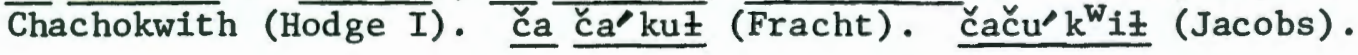

The information on this one is rather confusing. The notes on čme"'wa village state that the latter was the "same place as ča čolkuiz," and it is further stated that $\underline{\text { ca }}-\underline{c o}$ "kwiz was the "name of $\underline{|\bar{a}|}$ place," the place "now called Forest Grove" (the same location given for ča-čme.'wa (1877a:92, 94). However, the winter-village text (I infer that both the text and the notes on pages 92-97 were given by Peter) gives both names as names of settlements, and a marginal note on ča- $\check{c ̌ o}^{\prime} k w i z$ states that "they had a chief or subchief." Some evidence that the two names belonged to separate proximate locations is provided by the information that ča-ma'f.umyak ('place having ferns'), a mountain about two and a half miles north of Forest Grove, was between ča-čme.'wa and ča-čo'kwiz (1877a:97). It seems fair to speculate that if there indeed were two separate settlements

${ }^{1}$ For a-, read 'the .... 
here, they were likely near each other and perhaps closely interrelated.

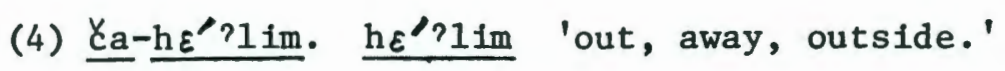

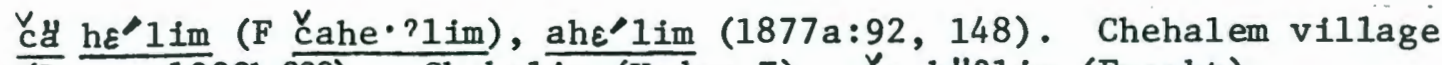

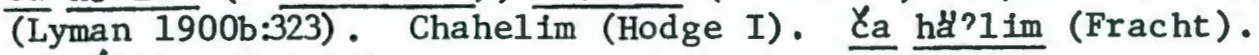

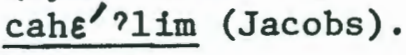

Located five to six miles south of Wapato Lake, in the vicinity of Chehalem Mountain and Valley (1877a:92). (See Figure 1, page 3, for a map giving coverage of the area.)

qa'yaqą, Peter's father's brother, was once chief there (1877a:92). The name of another former chief was wa'winxpa (1877a:148) (cf. Lyman [1900b:323]-- "a chief [at Chehalem village was Wow-na-pa").

(5) $\underline{\underline{a}-\underline{k \varepsilon^{\prime}} i p i} . \underline{-k \varepsilon^{\prime} i p i}$ 'beaver.'

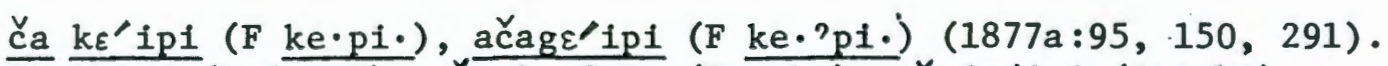
Chakeipi (Hodge I). ̌ㅡ ke.?pi. (Fracht). čaGe'ipi (Jacobs).

About six to ten miles west of Oregon City, (at?) "Beavertown" (i.e., at a place called by the Whites "Beavertown"?) (1877a:95). This description points to the locale of Beaverton (which occupies the former site of an extensive marsh).

$\underline{x \varepsilon^{\prime} / \text { uba, }}$ a notable hunter, was chief $(1877 a: 95,150)$. Dave's father was from there (1877a:95). Dave himself, in explanation of the name, noted that "the people were stout, heavy set people, hunters," also that there were "many beavers there" (1877a:291).

(6) ㅌa-ku'tpalyu: - $11^{\prime} \mathrm{yu}$ 'prairle' (I am unable to analyze the rest). 
ča ku/tpa1iu, ačagU/tpaliu (F ku/tpa?1yu) $(1877 a$ k95, 150, 291). Koot-pah1 (Lyman 1900b:323; said to be an Indian village near the old Alvin T. Smith place at Forest Grove). Chakutpaliu (Hodge I). Ca $\mathrm{ku}^{\prime} \mathrm{tpa}^{2} \mathrm{yyu}^{\circ}$ (Fracht). ČaGu'Dpalyu (Jacobs).

The location given by Lyman does not agree with that given by the Gatschet notes. In the latter, the location is given as being east of

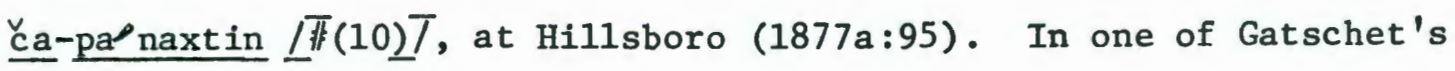
texts, the name is also applied to Hillsboro (the early settlers' town) (1877a:123). There was a prairie there which was five to six miles long (1877a:95)

"Tim" and $\underline{s_{i}^{\prime} 1 \cdot u k w a}$ were from this village (1877a:29).

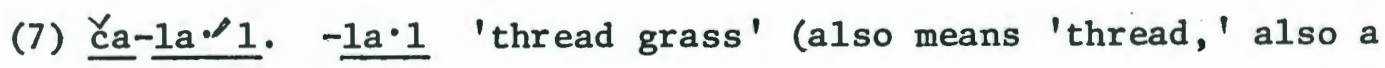
disease object extracted by shamans).

ča $1 \mathrm{a} \cdot 11$, ča $1 \mathrm{a}^{\prime} 1$ (1877a:92, 304). Chalal (Hodge I).

Located in the vicinity of a prairie, the latter beyond (north of) Wapato Lake, at its outlet $(1877 a: 92)$. Reference to the federal land survey records from the 1850 's shows that at that time there were two notable patches of prairle just north of Wapato Lake (see Figure 3). One, of about a square mile in extent, was only about a half mile from the lake and just across the upper Tualatin River from its outlet. The other, about half as large, was about a mile and a half from the lake, at the outlet of Scoggin's Creek. Some further information is given on the locar tion of ča-la.'1, in the mention of three names of early settlers said to have settled "at" ㅌa-1a./1: "McCloud," Jake Doren, and "Davison." Rer ference to Donation Claims data and the knowledge of Robert Benson (the former being made possible by the latter) puts "McCloud" (Donald McLeod, 
settled claim January 1850) on a good share of the larger of the two noted prairies (the claim occupying most of section 35, TIS R4W). Immediately north of McLeod's claim was the claim of Joseph Davis (settled October 1850; I suspect this to be the "Davison" referred to), which occupied most of section 26 of the same township, taking up most of the rest of the prairie land in question. Jake Doren's claim is not recorded in the Donation records, probably because, as noted by Gatschet's informant, he left after a relatively short time. There 1s, however, evidence that Doren did once live somewhere in the area (Benson 1975, p.c.); the fact that "Doren's Creek" has been recorded as an earlier name of Scoggin's Creek (Gibbs and Starling 1851) suggests that he lived somewhere near lower Scoggin's Creek.

The chief at $\mathrm{Ka}_{\mathrm{a}}-\underline{\mathrm{a}} \cdot / 1$ was named $\underline{\mathrm{s} l \mathrm{a}^{\prime} / \text { win }}$ (1877a:92).

(8) ̌a-1a/?wai.

ča 1a/ua1 (F 1a.?wa1), ačala//uai (F 1a?wai) (1877a:93, 149). Chalawi (Hodge I). ̌a la?wai (Fracht). DJala'?wai (Jacobs).

Probably located somewhere near the northeast shore of Wapato Lake. "S. E. of ča $1 a^{\prime} 1$, end of Wapp. /WTapatol 1ake" (1877a:93); "north of I Wapatof 1ake" (1877a:149).

"Tribe" said by Peter to be extinct in his time (1877a:93).

(9) Ča-ma'mpit. mam-pit 'creek'

ča ma'mpit, ačama'mpit $(1877 a: 93,149)$. Chamampit (Hodge I). ̌̌a ma'mpith (Fracht). 膏a mBit (Jacobs).

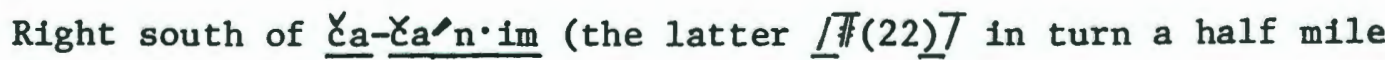
east of $\underline{\mathrm{Ca}_{a}}-\underline{\underline{a} \cdot / 1}$, east of Wapato Lake, on a creek running into the lake 
(1877a:93). The most notable creek running into the east side of Wapato Lake bed is Hill Creek, and I accordingly treat it as the likeliest location for this village. The notes give the name Wapato Creek, which is currently the name of a smaller creek entering the west side of Wapato Lake bed. The coincidence of names is probably insignificant.

$\underline{y} \varepsilon^{\prime} l \cdot u k t 1$ lived there; the father of kana/tamax (a woman) was chief $(1877 a: 93)$.

(10) Ca-pa/naxtin.

ča pa'naxtin, apa'na·xtin (1877a:95, 150). Chapanaghtin (Hodge I). a pa/naxtin (Fracht). Čapa/naxpin (Jacobs).

North of Hillsboro (1877a:95). This was probably the northermmost Tualatin village, as it is noted that north from "half the mountin at pa'naxtin" lay Clatskanie country (1877a:151-152). Probably located somewhere in the vicinity of the large prairie area which occupied most of the eastern half of township TIN R3W (see Figure 3). This inference is based on Dave's information (1877a:291) which gives ča-pa'l ha'liu (probably, 'place at the big prairie' I-pal 'big,' ha-liu 'prairie'T) as a name of the country of the a-pa'naxtin; the largest prairie in the general area was that noted above.

Robert Benson $(1959: 67)$ makes the plausible suggestion that the "pumpkin" in Pumpkin Ridge, a mountain directly north of the former large prairie noted above, may be a corruption of "pa'naxtin" (pa'noktIn, pə/nkIn, pəompkIn ?).

The name of the chief at pa'naxtin was pa'xawatas (1877a:95) (Louls Kenoyer also bore this name, which Jacobs writes Baxawa'tas). 
(11) $\complement_{a}-p \varepsilon^{\prime} k 11 .-p \varepsilon^{\prime} k 11$ '(steep) hill.'

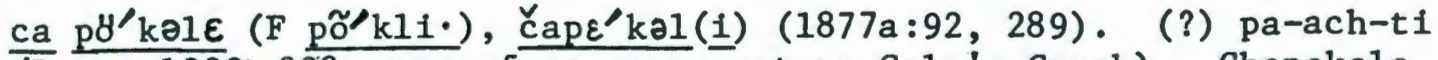
(Lyman 1900b:323; name of an open spot up Gale's Creek). Chapokele (Hodge I).

Three to four miles west of Wapato Lake (1877a:92). This vague information seemingly points to Patton Valley. Lyman's information, if indeed he is giving the same name, points farther north.

Peter indicated that the chief at ča-pe $\varepsilon^{\prime} k l 1$ was named $1 a^{\prime}$ wicxen. Dave, on the other hand, asserted that although the latter was a hunter he was not a chief (1877a:289).

(12) ča-pu'ngatpi. According to Dave's (1877a:289) suggestion, ga'tpi is a place or group name, pun- (stands for?) $\mathrm{pu}^{\prime} \mathrm{n}$ ni'm・ai '(they) make their-fire' ( $\mathrm{pu}^{\prime} \mathrm{n}$ 'make, do,' ni'm.ai 'their-fire'), referring to the deliberate setting of land fires to burn away brush or drive deer (the full name is then $\mathrm{pu}^{\prime} \mathrm{n} \mathrm{ni}^{\prime} \mathrm{m} \cdot \mathrm{ai}$ ga'tpi?). This etymology seems uncertain.

Ca pU'ngatpi (F pu'nikatpi), ačapU'ngatpi, apU/ngatphi (1877a:92, $\overline{149}, 270,303)$. Chapungathpi (Hodge I). ca pu'nkatpi. (Fracht). DJapu/nGatpi (Jacobs).

The location is unfortunately confusingly given. Peter says "on Wapato Lake, Forest Grove" (1877a:92); however, he also says (1877a:95) that the place called Candyădmčl (the Gaston petroglyphs, a well-known artifact located in Patton Valley about three and a half miles west of Gaston; see below) was two and a half miles east of Ca-pu'ngatpi, which information warld put this village well up into Patton Valley, near Cherry Grove. However, a slip by the informant or by Gatschet, "east" where "west" was meant (I have elsewhere verified such a slip involving the same-informant), would put 
this village near Wapato Lake, probably somewhere near Gaston, Confirmation for the latter possibility is provided in a note on the attempted assassination of Dave (cf. text in Jacobs 1945:169-170). The location of this action is noted to have been in the vicinity of $\underline{c a-1 a \cdot / 1}$ / ča-ta'gšiš we/i-ył'1biu (1877a:312). The latter translates as 'the wood at ta'gšiš' (-yひّ'1biu 'timber, woods, brush'), ča-ta'gšiš being the name

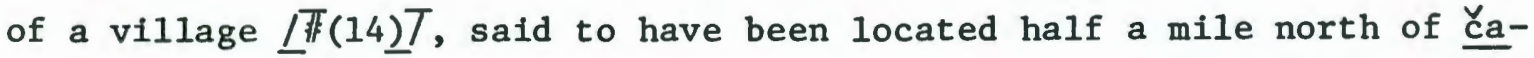
pu'ngatpi. This information apparently locates ča-ta'gšiš near ča-la/1, and consequently also locates ča-pu'ngatpi somewhere near (south of?) ča-la./1, i.e., probably somewhere near the north end of Wapato Lake (note that the information on the approximate location of ča-la./1 seems particularly reliable). A further possible clue here is provided in Mallery's "Pictographs of the North American Indians" (Ma1lery 1886:2526):

Mr. Albert S. Gatschet reports the discovery of rock etchings near Gaston, Oregon, in 1878, which are said to be near the ancient settlement of the Tualati (or Atfalati) Indians, according to the statement of these people. These etchings are about 100 feet above the valley bottom, and occur on six rocks of soft sandstone, projecting from the grassy hillside of Patten's / $\mathrm{PattonT} V a 11$ ey, opposite Darling Smith's farm /according to Donation Claim records, the claim of Darias and Mary Jane Smith was located in sec. 33, T1S R4W--this definitely identifies these "etchings" as the Gaston petroglyphs 7 , and are surrounded with timber on two sides. The distance from Gaston is about 4 miles; from the old Tualati settler ment probably not more than $2 \frac{1}{2}$ miles in an airline.

The above passage surely describes the place called by the Tualatin

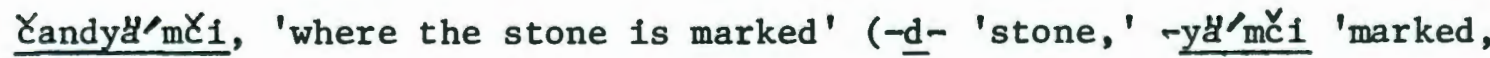
spotted'). According to the 1877 a MS, this consists of "pictures" carved on stone, located six miles from Gaston and half a mile from the Tualatin River, made "some 80 years ago" II.e., about $1800 T$ by Tillamooks who had come to attack the Tualatin (1877a:95). The discrepancies between the 
latter information and that given by Mallery (cf. the complete relevant passage from the latter) seem insignificant. If the noted "old Tualati settlement" was Ča-pu'ngatpi (which, recall, is given as being two and a half miles from Čandyम̆/mči), this village was probably located a mile or two west of Gaston, in lower Patton Valley.

Peter's father, $\underline{\mathrm{ka} / \mathrm{m} \cdot \mathrm{oc}}$ (Jacobs has $\underline{\mathrm{ka} \mathrm{m}^{\mathrm{m}} \cdot \mathrm{ac} \text { ) }}$ ), became chief of $\underline{\text { ca- }}$ pu'ngatpi after the previous chief, to'kwai, died (1877a:92, 270,303). Elsewhere, it is stated that $\mathrm{ka}^{\prime} \mathrm{m} \cdot \mathrm{oc}^{\prime} \mathrm{s}$ elder brother, Caki'lxida, was chief of ča-pu'ngatpi (1877a:150) (no indication whether the brothers were chiefs at the same or different times).

(13) غ̇a-ta'giz. -ta'giz 'fir bark' (or heavy bark of any kind?). ča ta/giz (F ta'q1̇), ačata'giz $(1877 a: 93,149)$. Chatagith1 (Hodge I). ča ta'kiz (Fracht). EaDa'Giz (Jacobs).

Located about a mile right southwest from Wapato Lake (1877a:93). kali'čadax (elsewhere, kwali'čad $\left.{ }^{a} x\right)$ was chief $(1877 a: 93,149)$.

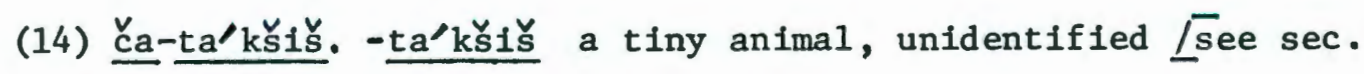
$10 \mathrm{~g}, \#(4) \mathrm{T}$.

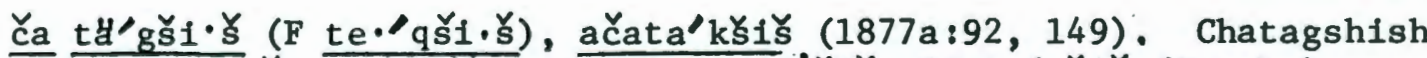

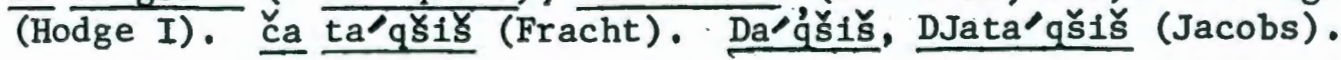

Located about a half mile north of čarpu'ngatpi (1877a:92). Chief mä'nšta (elsewhere, ma'nI'šta); another name of the same man was

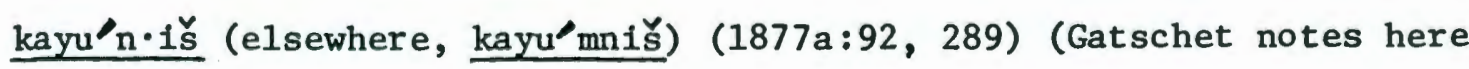
that Tualatins of ten changed names). 


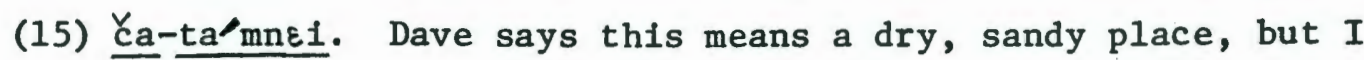
am unable to analyze the name.

ča ta'mnei (F ta'mni.) (1877a:92). Tahm-yahn (Lyman 1900b:323; Indian name of David Hill, northwest of Forest Grove). Chatamnei (Hodge I).

Noted to be the name of a place, former1y inhabited, "tribe" extinct by later historical times. Located about 10 miles north from Wapato Lake (1877a:92) (the above information from Lyman suggests David Hill as the location). Much a.1d (an edible root $\underline{\overline{s e c}} \cdot 10 \mathrm{a}-1$, 非( $28 \underline{X} \underline{T})$ grew there (1877a:92).

(16) $\underline{c a-t i ' 1 k w \varepsilon i . ~}$

ča ti'lkuєi, ačati'1kuєi, čati'lkue/11 (1877a:70, 93, 149). Chat1lkuei (Hodge I). ̌ㅡ ti'lkwi. (Fracht). ačaDi'lkwei, caDi/ $1 \mathrm{k}^{\mathrm{W}} \mathbf{I}$ (Jacobs).

West of Chehalem (Valley?) and about five miles west of Wapato Lake (1877a:93); below (downstream from?) the north fork of Yamhill River, the district below McMinnville (1877a:70) (vicinity of Lafayette?). This is the only definite mention of a Tualatin village in the Yamhill River drainage. (See Figure 1, page 3, for a map giving coverage of the area.)

Dave thought that this was not a village, merely an uninhabited place (1877a:290). However, Peter noted that the chief of this village was the father of a woman living at Grand Ronde around 1877 (1877a:93).

(17) Ča-waye./d.

ča uaye.'d, ača/uaye.'d (F wa'yid) (1877a:149). Chawayed (Hodge I).

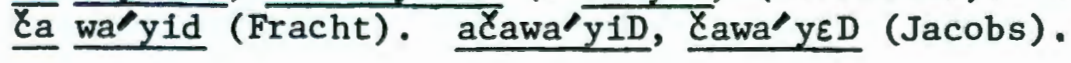


Located two to three miles west of ča-pu'ngatpi (1877a:149). It is noted that Peter believed that "they had a chief," also that there was a big graveyard there, still visited by the people at Grand Ronde circa 1877 (1877a:149).

12b. Village or Place Names: Information Insufficient to Identify Clearly

(18) ̌a ever, the etymology is not entirely clear to me (elsewhere, -bit is 'creek,' ma'n-člal 'river').

ča ča'mbit ma'nčal (1877a:291). Chachambitmanchal (Hodge I).

A prairie and river, inhabited, located about three and a half miles north of Forest Grove (1877a:291) (West Dairy Creek or main Dairy Creek?).

(19) ča-go \%ndwEftei. Said to mean 'where the road (or trail) comes out' (go.n 'road, trail').

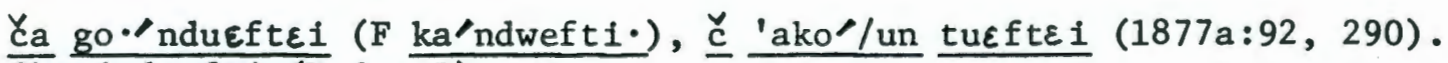
Chagindueft 1 (Hodge I).

Between Ca-pa'naxtin and Sauvie's Island (1877a:90). I.e., where the trail over the Tualatin Mountains to Sauvie's Island comes out onto Tualatin Plains?

(20) ča-pa'1 ha'liu. Probably means 'place at the big prairie' (-pal 'big;' ha'-1iyu 'prairie').

čapa'1 ha'liu (1877a:291). 
The country of the apa'naxtin /see 非(10)T, north of ča čalmbit ma'nčal (1877a:291).

(21) ča-takwi'n.

čatakui'n (1877a:291). Chatakuin (Hodge I).

A prairie and river, four miles from Hillsboro and seven miles from Forest Grove, north (1877a:291) (McKay Creek?).

12c. P1ace Names, Erroneous1y Identified as Village Names in Hodge (1907)

(22) $\underline{\epsilon a}_{a}-\underline{c_{a}} n \cdot i m$.

ča ča'n+im (1877a:93). Chachanim (Hodge I).

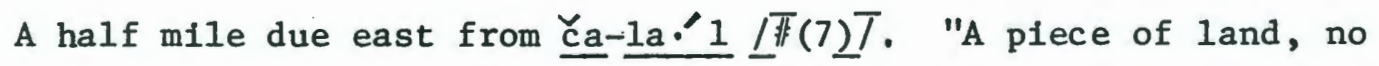
chief" (1877a:93).

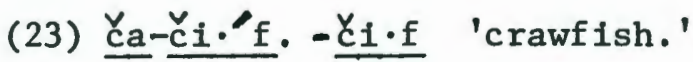

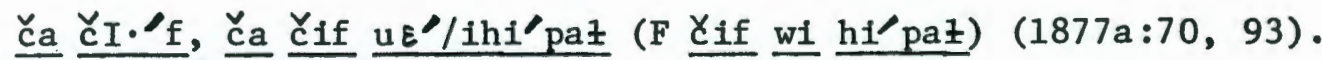
Chachif (Hodge I).

On the northern end of Wapato Lake; an Important site for the digging of Sagittaria (wapato) roots, used in common by all of the Tualatins ("the whole tribe") (1877a:70,93). 


\section{REFERENCES}

Allen, A. J.

1850 Ten Years in Oregon. Ithaca, New York: Press of Andrus, Gauntlett, and Co.

Applegate, Jesse A.

1907 The Yangoler Chief. Roseburg: Review Publishing Co.

1930 Recollections of My Boyhood. Pp. 85-218 in The Oregon Trail, by Maude A. Rucker. New York: Walter Neale. (Original:

Roseburg: Review Publishing Co., 1914.)

Bailey, Vernon

1936 The Mammals and Life Zones of Oregon. North American Fauna No. 55. Washington.

Belden, G. H.

[ca. Sketch Map of Oregon Territory, Exhibiting the Locations of

1855] the Various Indian Tribes, the Districts of Country Ceded by Them, with the Dates of Purchases and Treaties, and the Reserves of the Umpqua and Rogue River Indians. (Manuscript in National Archives, Cartographic Records Division, Map 234, Tube 451.)

Benson, Robert

1959 The Tualatins. In A Centennial History of Washington County, Oregon. Hillsboro: Washington County Historical Society.

1975 Personal communications.

$-76$

Boyd, Robert

1975 Another Look at the "Fever and Ague" of Western Oregon in the Early 1830's. (Paper read at the 28th Annual Northwest Anthropological Conference, Seattle Central Community College, Seattle, March 1975.)

Cahalane, Victor H.

1967 The Imperial Collection of Audobon Animals. New York: Bonanza Books.

Clark, George L.

1954 Elements of Ecology. New York: John Wiley and Sons.

Cleaver, F. C.

1951 Fisheries Statistics of Oregon. Oregon Fish Commission, Contribution No. 16. Portland. 
C1yman, James

1960 James Clyman, Frontiersman [journals kept by James Clyman between 1840 and 1871]. Charles L. Camp, ed. Portland: Champoeg Press.

Cobb, John N.

1930 Pacific Salmon Fisheries. Appendix XIII to the Report of the Commissioner of Fisheries for 1930. Washington.

Cook, S. F.

1955 The Epidemic of 1830-33 in California and Oregon. University of California Publications in American Archaeology and Ethnology $43(3): 303-326$.

Coues, E11iot

1897 New Light on the Early History of the Greater Northwest: the Manuscript Journals of Alexander Henry and of David Thompson, 1799-1814. Vo1. 2. New York: Francis P. Harper.

De Angulo, Jaime, and Lucy S. Freeland

1929 The Tfalati Dialect of Kalapuya. (Unpublished grammatical sketch and texts, Box 71, Folder 71.3, Melville Jacobs Collection, University of Washington, Seattle.)

Dickson, Evelyn M.

1946 Food Plants of Western Oregon Indians. (Unpublished M.A. thesis in Education, Stanford University, Stanford, Calif.)

Douglas, David

1904 Sketch of a Journey to the Northwestern Part of the Continent

-05 of North America During the Years 1824-25-26-27. In six parts. The Quarterly of the Oregon Historical Soclety 5 $(3,4), 6(1,2,3,4)$.

1959 Journal Kept by David Douglas During His Travels in North America, 1823-1827. New York: Antiquarian Press Ltd. (Reprint of edition published in 1914 by William Wesley \& Son, London.)

Forbes, Richard

1976 Personal communication.

Frachtenberg, Leo J.

1913 Kalapuya: Texts. (Manuscript fleldnotes, catalogue no.

-14a 1923-a, National Anthropological Archives, Smithsonian Institution, Washington.)

1913 Kalapuya: Grammatical Notes. (Manuscript fleldnotes, cata-14b logue no. 1923-d, National Anthropological Archives, Smithsonian Institution, Washington.) 
1913 [Yamhill Kalapuyan: vocabulary and grammatical notes.]

-14c (Manuscript field notes, catalogue no. 1923-e, National Anthropological Archives, Smithsonian Institution, Washington.)

1914a Kalapuya: Ethnology. (Manuscript field notes, catalogue no. 1923-c, National Anthropological Archives, Smithsonian Institution, Washington.)

1914b [Yonca1la Kalapuyan: vocabulary and grammatical notes.] (Manuscript field notes, catalogue no. 1923-f, National Anthropological Archives, Smithsonian Institution, Washington.)

[ca. [Tualatin, Yamhil1, Mary's River, Santiam, and Lower McKen1915] zie texts.] (Manuscript typescripts in Box 70, Folder 70.9, Melville Jacobs Collection, University of Washington, Seattle.)

Franchere, Gabriel

1954 A Voyage to the Northwest Coast of America. Chicago: Lakeside Press. (Translation of French original published in Montreal, 1820.)

French, David

1975 Personal communications.

$-76$

Gabrielson, Ira N. and Stanley G. Jewett

1970 Birds of the Pacific Northwest; With Special Reference to Oregon. New York: Dover Publications. (Reprint of Birds of Oregon, Corvallis, 1940.)

Galbreath, James L.

1965 Timing of Willamette River Spring Chinook Salmon Through the Lower Columbia River. Oregon Fish Commission Research Briefs $11(1): 29-41$.

Gatschet, Albert S.

1877a Texts, Sentences and Vocables of the Atfa'lati Dialect of the Kalapuya Language of Willa'met Valley, Northwestern Oregon. (Manuscript field notes, catalogue no. 472-a, National Anthropological Archives, Smithsonian Institution, Washington.)

1877b [Tualatin Kalapuyan: vocabulary.] (Manuscript vocabulary entered into Powell's Introduction to the Study of Indian Languages, first ed.; catalogue no. 472-d, National Anthropological Archives, Smithsonian Institution, Washington.)

Gharrett, John T. and John I. Hodges

1950 Salmon Fisheries of the Coastal Rivers of Oregon South of the Columbia. Oregon Fish Commission, Contribution No. 13.

Portland. 
Gibbs, George

1877 Tribes of Western Washington and Northwestern Oregon, Contributions to North American Ethnology 1:157-361, U. S. Geographical and Geological Survey of the Rocky Mountain Region. Washington.

Gibbs, George and E. A. Starling

1851 Sketch of the Wallamette [sic] Valley Showing the Purchases and Reservations Made by the Board of Commissioners to Treat with the Indians of Oregon, April and May 1851, . . (Manuscript in National Archives, Cartographic Records Division, Map 195, Tube 458.)

Habeck, James $R$.

1961 The Original Vegetation of the Mid-Willamette Valley, Oregon. Northwest Science 35(2):65-7.7.

Hale, Horatio

1846 Ethnography and Philology. United States Exploring Expedition During the Years 1838, 1839, 1940, 1841, 1842. Vol. 6. Philadelphia: C. Sherman.

Hajda, Yvonne P.

1976 Personal communication.

Hines, Gustavus

1881 Wild Life in Oregon. New York: Hurst \& Co. (Original: A Voyage Around the World With a History of the Oregon Mission . . , Buffalo, 1850.)

Hitchcock, C. Leo, Arthur Cronquist, Marion Ownbey, and J. W. Thompson

1961 Vascular Plants of the Pacific Northwest. In five parts. University of Washington Publications in Biology 17. Seattle.

Hodge, Frederick W., ed.

1907, Handbook of American Indians North of Mexico. Bureau of

1910 American Ethnology, Bulletin 30. Washington.

Hodges, John I. and John T. Gharrett

1949 Tillamook Bay Spring Chinook Salmon. Oregon Fish Commission Research Briefs 2(2):11-16.

Holmes, Harlan and Milo Bell

1960 A Study of the Upstream Passage of Anadromous Fish at Willamette Falls, With Recommendations for Improvements in FishPassage Facilities. (Typewritten manuscript at Oregon Historical Soclety Library.)

Hussey, John A.

1967 Champoeg: Place of Transition. Portland: Oregon Historical Society. 
Ingles, Lloyd G.

1965 Mammals of the Pacific States, Stanford: Stanford University Press.

Jacobs, Melville

1928 [Yoncalla Kalapuyan: vocabulary, grammatical and ethnologic notes.] (Field Notebook No. 45, Box 51, Melville Jacobs Collection, University of Washington, Seattle.)

[ca. [Santiam Kalapuyan: text translations and ethnologic notes.]

1928] (Manuscripts in Box 70, Folder 70.4, Melville Jacobs Co1lection, University of Washington, Seattle.)

1928 [Santiam Kalapuyan: texts, vocabulary, grammatical and eth-

-36 nologic notes.] (Field Notebooks Nos. 33-37, 46-47, 76-90, in Boxes Nos. 50, 52, 55, 56, Melville Jacobs Collection, University of Washington, Seattle.)

[ca. [Notes for a Clackamas ethnography.] (Manuscripts in Box

1929 119, Melville Jacobs Collection, University of Washington,

-30 ] Seattle.)

1935 [Yoncalla Kalapuyan: vocabulary.] (Field Notebook No. 110, Box 58, Melville Jacobs Collection, University of Washington, Seattle.)

[ca. A Tualatin Kalapuya Autobiographic Fragment with Some Other

1936 Tualatin Texts. (Manuscript in Box 71, Folder 71.1, Melville

a] Jacobs Collection, University of Washington, Seattle.)

[ca. Kalapuya Element List. (Manuscript in Box 70, Folder 70.5,

1936 Melville Jacobs Collection, University of Washington,

b] Seattle.)

1945 (See Jacobs, Gatschet, Frachtenberg 1945.)

Jacobs, Melville, Albert S. Gatschet, and Leo J. Frachtenberg

1945 Kalapuya Texts. University of Washington Publications in Anthropology 11. Seattle. (Cited in text as Jacobs 1945.)

Johannessen, Carl L., W. A. Davenport, Artimus Millet, and S. McWilllams

1971 The Vegetation of the Willamette Valley. Annals of the Association of American Geographers 61(2): 286-302.

Kappler, Charles J., ed.

1904 Indian Affairs: Laws and Treaties. Vo1. 2. Washington.

Kruse, Anne Applegate

1954 The Halo Trail: The Story of the Yoncalla Indians. Drain, Oregon: The Drain Enterprise. 
Lane, Joseph

1849 [Annual Report of the Superintendent of Indian Affairs, Oregon Territory.] (Letters received by the Office of Indian Affairs, Oregon Superintendency, National Archives Microcopy No. 234, Roll 607.)

Laughlin, W. S.

1943 Notes on the Archeology of the Yamhill River, Willamette Valley, Oregon. American Antiquity 9(2):220-229.

Lyman, H. S.

1900a Reminiscences of Louis Labonte. The Quarterly of the Oregon Historical Society 1(2):169-188.

1900b Indian Names. The Quarterly of the Oregon Historical Society $1(3): 316-326$.

Mackey, Harold

1974 The Kalapuyans: A Sourcebook on the Indians of the Willamette Valley. Salem: Mission Mill Museum.

Mallery, Garrick

1886 Pictographs of the American Indians: A Preliminary Paper. Fourth Annual Report of the Bureau of American Ethnology, pp. 3-256. Washington.

Minto, John

1900 The Number and Condition of the Native Race in Oregon When First Seen by White Men. The Quarterly of the Oregon Historical Society $1(3): 296-315$.

Mooney, James

1928 The Aboriginal Populations of America North of Mexico. Smithsonian Miscellaneous Collections 80(7):1-40.

Newe11, Robert

1959 A Report on the Indians of Sub-Agency First District South of the Columbia [1849]. Pp. 143-159 in Robert Newe11's Memoranda, Dorothy 0. Johansen, ed. Portland: Champoeg Press.

Ogden, Peter Skene

1950 Peter Skene Ogden's Snake Country Journals: 1824-25 and 1825-26. E. E. Rich, ed. The Publications of the Hudson's Bay Record Society 13. London.

Palmer, Joel

1847 Journal of Travels Over the Rocky Mountains, to the Mouth of the Columbia River, Made During the Years 1845 and 1846. . Cincinnat1: J. A. \& U. P. James.

Pearson, T. G., ed.

1936 Birds of America. New York: Garden City Publishing Co. 
Peck, Morton E.

1961 A Manual of the Higher Plants of Oregon. Second edition. Portland: Binfords \& Mort.

Powe11, J. W.

1891 Indian Linguistic Families of America North of Mexico. Seventh Annual Report of the Bureau of American Ethnology, 1885-86. Washington.

Ramsdel1, T. M.

1907 Indians of Oregon; Retrospective Reminiscences. (Manuscript No. 852, Oregon Historical Society Library, Portland.)

Rees, Willard $\mathrm{H}$.

1880 Annual Address. Transactions of the Seventh Annual Re-union of the Oregon Pioneer Association, pp. 18-31. Salem.

Riddle, George W.

1920 History of Early Days in Oregon. (Fascimile reproduction by the Shorey Book Store, Seattle, 1968.)

Riggs, James

1975 Personal communication.

Robbins, Chandler S., Bertel Bruun, and Herbert S. Zim

1966 Birds of North America. New York: Golden Press.

Roe, Ruth

1974 Personal communication.

Ross, Alexander

1849 Adventures of the First Settlers on the Oregon or Columbia River. London: Smith, Elder.

Schoning, R. W., T. R. Merrill, and D. R. Johnson

1951 The Indian Dip Net Fishery at Celilo Falls on the Columbia River. Oregon Fish Commission, Contribution No. 17. Portland.

Schrenkeisen, Ray

1963 Field Book of Fresh-water Fishes of North America North of Mexico [1938]. T. J. Nichols and F. R. La Mente, eds.

New York: G. P. Putnam's Sons.

Smith, Silas B.

1901. Primitive Customs and Religious Beliefs of the Indians of the Pacific Northwest Coast. The Quarterly of the Oregon Historical Society $2(3): 255-265$.

Spier, L., and E. Sapir

1930 Wishram Ethnography. University of Washington Publications in Anthropology 3:151-300. 
Sprague, F., and H. Hansen

1946 Forest Succession in the McDonald Forest, Willamette Valley Oregon. Northwest Science 20(4):89-98.

Stebbins, Robert C.

1954 Amphibians and Reptiles of Western North America. New York: McGraw-Hill.

Strong, Thomas $\mathrm{N}$.

1906 Cathlamet on the Columbia. Portland: Binfords \& Mort.

Stuart, Robert

1953 On the Oregon Trail: Robert Stuart's Journey of Discovery

[1812-13]. Kenneth A. Spaulding, ed. Norman: University of Oklahoma. Press.

Swadesh, Morris

1965 Kalapuya and Takelma. International Journal of American Linguistics $31(3): 237-240$.

Taylor, H. C., Jr.

1963 Aboriginal Populations of the Lower Northwest Coast. Pacific Northwest Quarterly $54(4): 158-166$.

Thwaites, Reuben Gold., ed.

1905 Original Journals of the Lewis and Clark Expedition, 18041806. 7 vols. New York: Dodd, Mead \& Company,

United States Survey

1852 [Field notes for T2S R4W.] (Federal land-survey records, Oregon State Office, Bureau of Land Management, Portland.)

[ca. [Township sketches.] (Federal land-survey records, Oregon

1851 State Office, Bureau of Land Management, Portland.)

$-56]$

Wilkes, Charles

1845 Narrative of the United States Exploring Expedition During the Years 1838, 1839, 1840, 1841, 1842, 5 vols. and an atlas. Philadelphia: Lea \& Blanchard.

Willamette River Project, Carlton Division

[ca. [Checklists of plants and animals known to occur in the

1972] Yamhill River basin.] (Unpublished data, Willamette River Project, Carlton Division, Bureau of Reclamation, Salem.)

Work, John

1923 John Work's Journey from Fort Vancouver to Umpqua River, and Return, in 1834. Leslie M. Scott, ed. The Quarterly of the Oregon Historical Society $24(3): 238-268$. 
Wyeth, Nathanie1 J.

1899 The Correspondence and Journals of Captain Nathaniel J. Wyeth, 1831-6. F. G. Young, ed. Eugene: University of Oregon Press. 


\section{APPENDIX}

PHONOLOGY AND TRANSLITERATION

\section{Phonology}

Linguistic forms appearing in this thesis are transliterated, without phonemic interpretation, just as they are given by the cited authorities, with the exception that, for the sake of simplification, I often take the liberty of writing $\underline{u}$, $\underline{i}$ in place of their free variants $\underline{U}, \underline{I}$ (see footnotes 1 and 3 on page 167), and w, $y$ in place of Gatschet's consonantal $\underline{u}$, $\underline{i}$; I take no such liberties, however, with the lists of plant and animal terms given in sec. 10--a11 of the names in question are strictly transliterated.

All of my phonetic symbols for the Tualatin-Yamhill language are given in the following charts; I am much indebted here to Yvonne Hajda for her advice on numerous points. Parentheses enclose probable allophones of the same phoneme; not all probable phonemic equivalences are shown, since a complete phonemic analysis of Tualatin has not been undertaken at this point. 


\section{Consonants}

$\begin{array}{ll}\text { Obstruents } & \text { Fricatives Resonants Gildes } \\ \text { Plain Glottalized } & \end{array}$

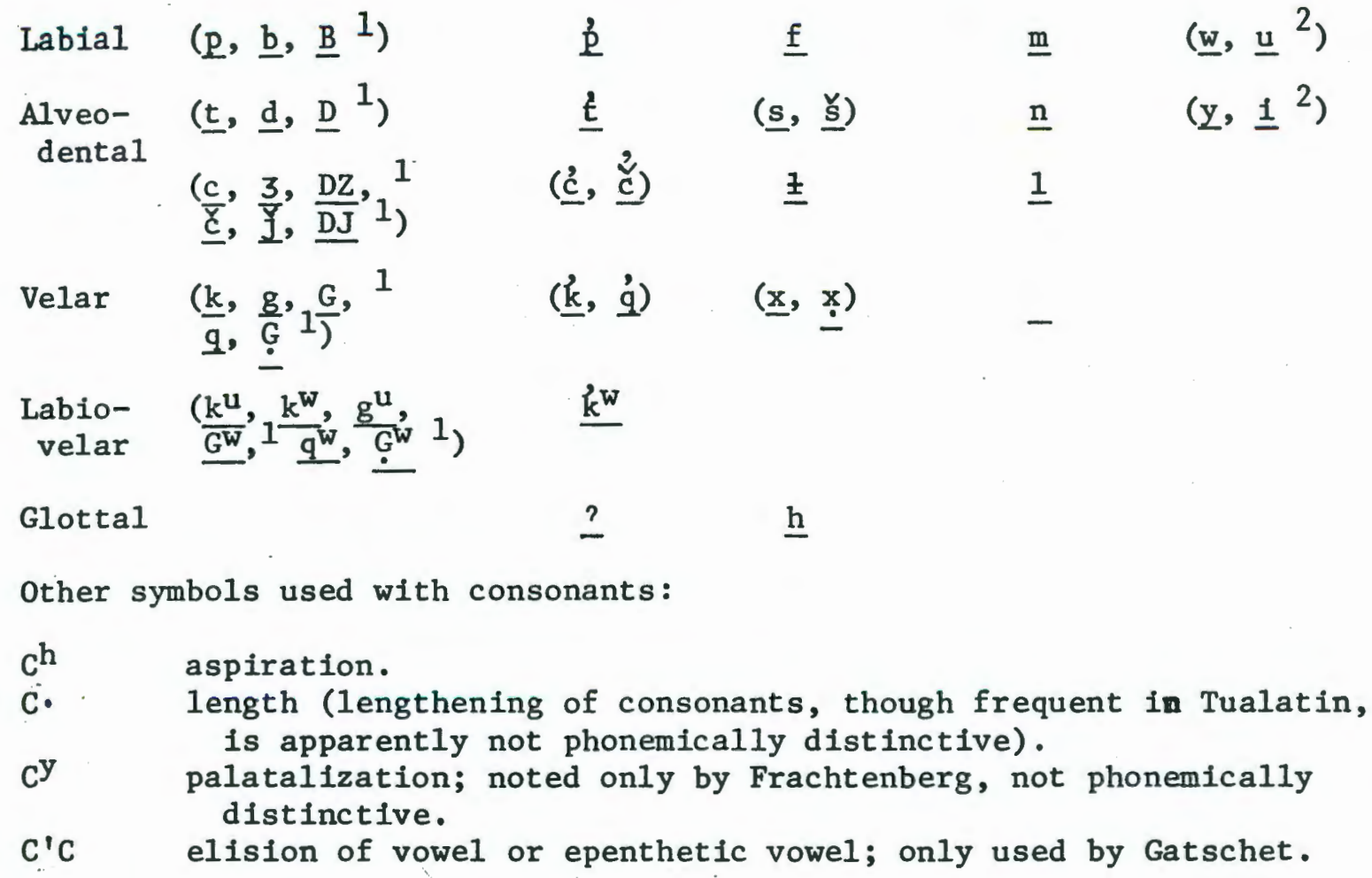

1Jacobs' "Intermediate" consonants (varying from inaspirate voicelessness to very brief sonancy; cf. Jacobs (1945:13-15, 151-153T); appear only in forms cited from Jacobs.

${ }^{2}$ Gatschet usually, though not always, writes $\underline{u}, \underline{1}$ for both consonantal $[w],[y]$ and the vowels $[u],[1]$. 


\section{Vowe1s}

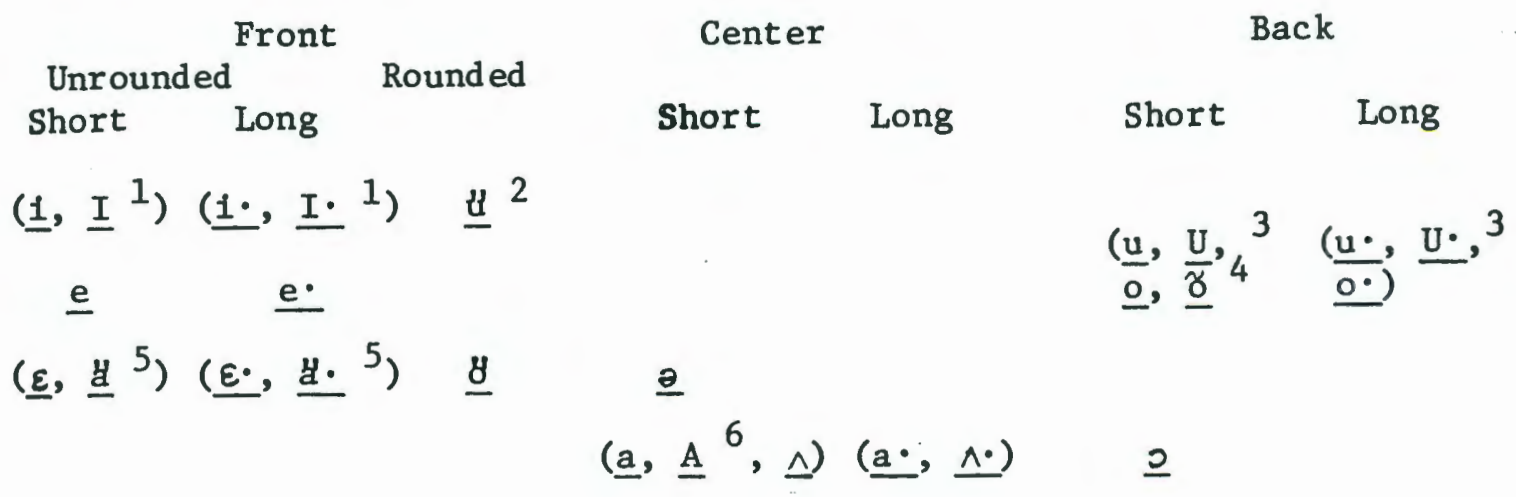

Other symbols used with vowels:

V/V syllable boundary, or hiatus between vowels which would otherwise form a diphthong-used only in forms cited from Gatschet (transliterates his dash, "-").

\section{Diphthongs}

(The actual phonemic units are certainly far fewer than those shown.)

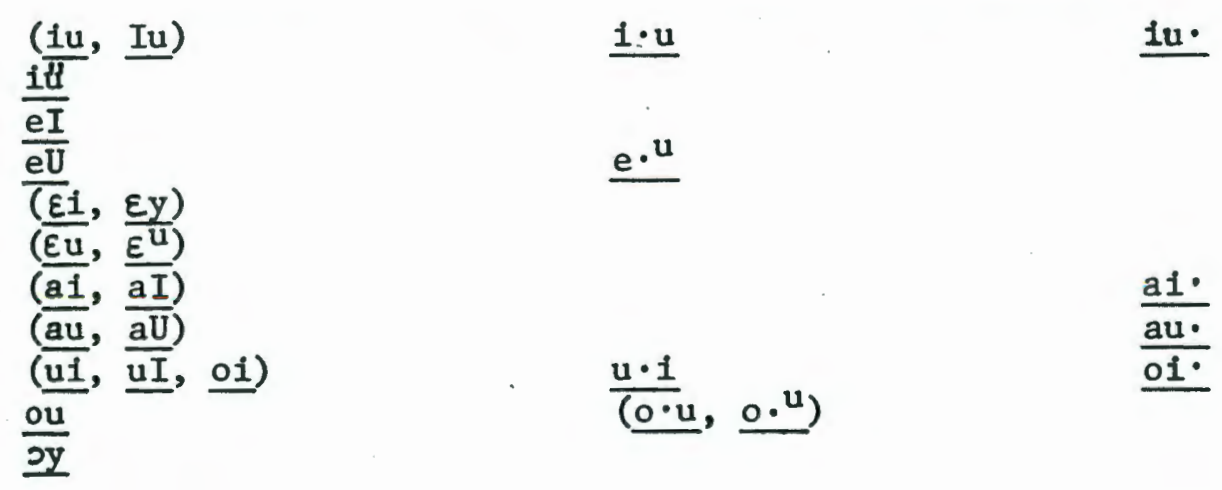

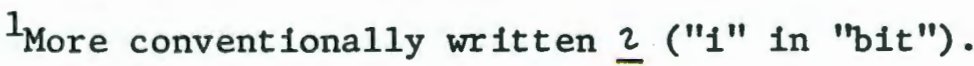

${ }^{2}$ occurs only in a few forms from Gatschet.

${ }^{3}$ More conventionally written $\underline{\vartheta}$ ("u" in "put").

${ }^{4}$ Occurs only in a few forms from Frachtenberg.

5 More conventionally, $\underset{x}{ }$ (approximately the sound of "a" in "mat").

${ }^{6}$ See footnote 3 on page 169. 
Transliteration

The following tables show only the variances between symbols used here and symbols used by cited linguistic authorities.

- means authority apparently does not record the sound symbolized,

(_) means authority's special symbol, retained here in forms cited from that authority.

\section{Consonants}

(Symbol used here)

[p̉ ]

[t]

[3]

[c]

[’́ ]

[ว] ]

[है]

[ह]

[ร̌]

[1]

$[\mathrm{L}]^{1}$

[k]

[q']

[?]
Gatschet Frachtenber

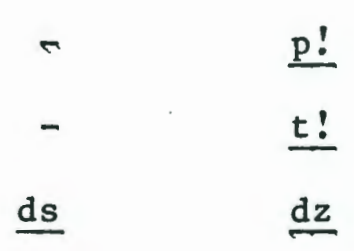

ts

- ts!

dsh

tch

-

sh

$t h^{1}, t h$,

$\underline{1 \mathrm{th}}, \underline{\mathrm{th} 1}$ $\underline{\mathrm{dz}}$

ts

ts

$\underline{t s}$

dj

tcc

tc

$\underline{t c}$

c

c
(DZ)

ts, (DZ)

$\underline{t s}$

(DJ)

tc, (DJ)

tcc

c

k!

g!

$\underline{\varepsilon}$

1"Surd lateraI" (?); appears only in a few forms from Frachtenberg; varies with $\underline{ \pm}$. 
(Symbol used here)

$$
\begin{aligned}
& c^{h} \\
& c^{\cdot} \\
& c^{y}
\end{aligned}
$$
consonants

$$
\text { - }
$$

[ə]

[I]

[ع]

[e]

[e.]

$[\mathrm{A}]^{3}$

[^]

[u]

V・
Doubles

Gatschet

Frachtenberg

$$
c^{e}
$$

$\overline{\mathrm{C}}$, or doubles

c.

Jacobs Freeland

$$
c^{c}
$$

Doubles

Vowe1s

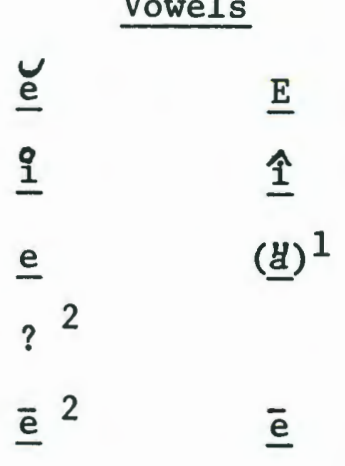

script $\underline{a}^{3}$

script $\underline{a}^{3}$

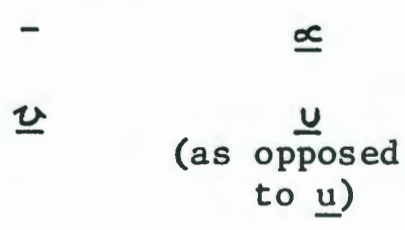

$\overline{\mathrm{V}} \quad \overline{\mathrm{V}}$

1Frachtenberg's $\mu$ apparently represents quality varying from $[\varepsilon]$ to [æ] (Yvonne Hajda $1 \overline{9} 76$, p.c.).

${ }^{2}$ In his description of Klamath phonology, Gatschet gives $\overline{\bar{e}}$ as "Ionger sound of e" (his [E]), e.g., German "Speer," "Wehr." I assume that the same statement holds for Tualatin, where the same symbols appear. It would seem, then, that Gatschet shows vowel quality and vowel length covarying for $[\varepsilon]-[e \cdot]$, although a few pages previously he had specifically stated that vowel quality and length are not interdependent in Klamath as they are in English.

3e Angulo gives this as, e.g., the "a" in French "patte." I do not know whether Gatschet meant the same sound. However, both authorities use this symbol to designate a sound which varies freely with [a], occurring much less frequently than the latter. 